\title{
CARACTERIZAÇÃO DA INTERAÇÃO ENTRE O METILOSSOMO E O NUCLEOCAPSÍDEO DO VIRUS RESPIRATÓRIO SINCICIAL
}

Dissertação apresentada ao Programa de PósGraduação em Microbiologia, do Instituto de Ciências Biomédicas da Universidade de São Paulo, para a obtenção do título de Mestre em Ciências.

São Paulo 


\section{CARACTERIZAÇÃO DA INTERAÇÃO ENTRE O METILOSSOMO E O NUCLEOCAPSIIDEO DO VÍRUS RESPIRATÓRIO SINCICIAL HUMANO.}

Dissertação apresentada ao Programa de PósGraduação em Microbiologia, do Instituto de Ciências Biomédicas da Universidade de São Paulo, para a obtenção do título de Mestre em Ciências.

Área de concentração: Microbiologia

Orientador: Prof. Dr. Armando Morais Ventura

Versão original 


\section{CATALOGAÇÃO NA PUBLICAÇÃO (CIP) \\ Serviço de Biblioteca e informação Biomédica \\ do Instituto de Ciências Biomédicas da Universidade de São Paulo}

Ficha Catalográfica elaborada pelo(a) autor(a)

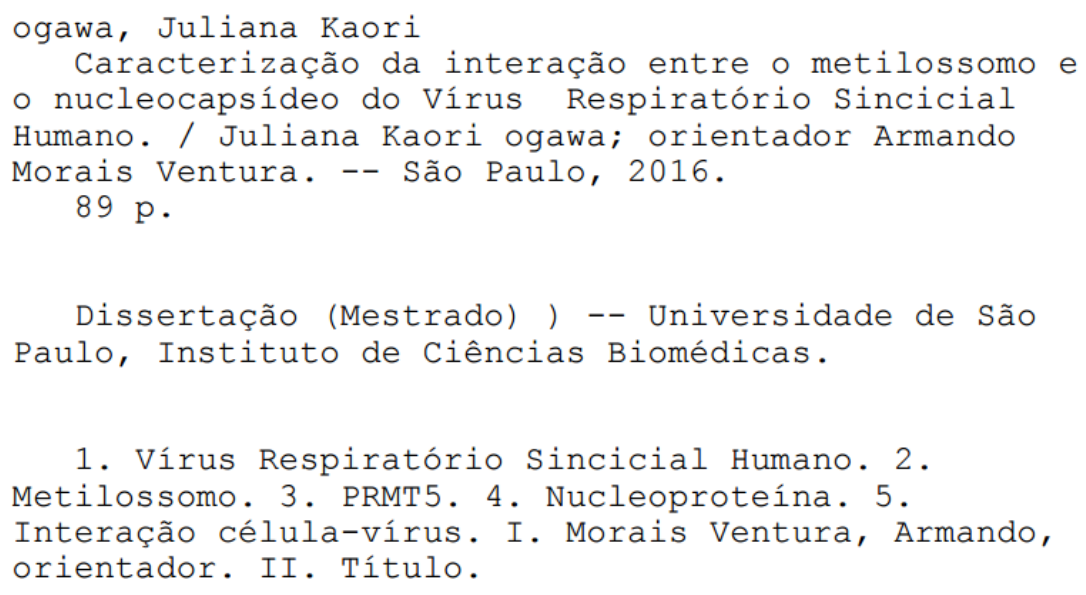


Candidato(a): Juliana Kaori Ogawa

Título da Dissertação: Caracterização da interação entre o metilossomo e o nucleocapsídeo do Vírus Respiratório Sincicial Humano

Orientador(a):Dr. Armando Morais Ventura

A Comissão Julgadora dos trabalhos de Defesa da Dissertação de Mestrado, em sessão pública realizada a . considerou

\section{( ) Aprovado(a) \\ ( ) Reprovado(a)}

Examinador(a): Assinatura:

Nome:

Instituição:

Examinador(a): Assinatura:

Nome:

Instituição:

Presidente: Assinatura:

Nome:

Instituição: 


\section{CERTIFICADO DE ISENÇÃO}

Certificamos que o Protocolo CEP-ICB N ${ }^{\circ}$ 645/14 referente ao projeto intitulado: "Caracterização da interação entre o metilossomo $e \quad o$ nucleocapsídeo do vírus respiratório sincicial humano" sob a responsabilidade de Juliana Kaori Ogawa, foi analisado na presente data pela CEUA - COMISSÃo DE Ética No uso DE ANIMAIS e pela CEPSH- COMISSÃo DE ÉTICA EM PESQUISA COM SERES HUMANOS, tendo sido deliberado que o referido projeto não utilizará animais que estejam sob a égide da lei 11.794 de 8 de outubro de 2008, nem envolverá procedimentos regulados pela Resolução CONEP nº466 de 2012.

São Paulo, 26 de fevereiro de 2014.

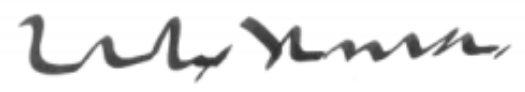

Prof. DR. WOTHAN TAVARES DE LIMA Coordenador da CEUA - ICB/USP

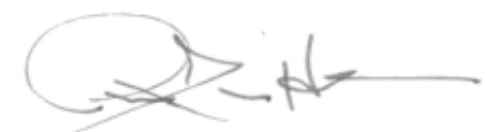

Pref. DR. PAOLO M.A ZaNotTo Coordenador da CEPsh - ICB/USP 
À minha família e ao Vitor Ponci 


\section{AGRADECIMENTOS}

A minha família, Emy, Roberto, Fábio e Vivian, pelo amor e apoio incondicional em todos os momentos. Obrigada por tudo, amo vocês!

Ao Vitor Ponci pelo amor, apoio e por sempre me incentivar a dar o meu melhor. Te amo!

Ao Prof. Dr. Armando Morais Ventura por me dar a oportunidade de realizar este trabalho, pela sua orientação e pelo aprendizado, crescimento e amadurecimento que isso me proporcionou.

Agradeço as amizades que fiz, pela companhia e apoio dos meus amigos de trabalho, Andressa, Cinthia, Márcia, Orlando, Stephanie e Tábata, pelas risadas e contribuições para este trabalho.

A todos do laboratório do Prof. Dr. Carlos Menk, Prof ${ }^{a}$. Drª . Rita Cássia e Prof. Dr. Luis Carlos pela convivência e empréstimo de equipamento.

Agradeço a FAPESP pela bolsa. 
"Descobrir consiste em olhar para o que todo mundo está vendo e pensar uma coisa diferente".

Roger Von Oech 


\section{RESUMO}

OGAWA, J. K. Caracterização da interação entre o metilossomo e o nucleocapsídeo do Vírus Respiratório Sincicial Humano. 2016. 86 f. Dissertação (Mestrado em Microbiologia) - Instituto de Ciências Biomédicas, Universidade de São Paulo, São Paulo, 2016.

O Vírus Respiratório Sincicial Humano (HRSV) é um dos patógenos mais importantes do trato respiratório. Esse vírus causa doença respiratória em recém-nascidos, bebês, crianças e em pacientes imunocomprometidos, sendo que até o momento não há vacina aprovada ou um antiviral eficiente e com custo acessível, disponível para utilização em larga escala. O genoma do HRSV codifica 11 proteínas, sendo fundamental para entender a relação patógenohospedeiro, caracterizar suas interações na célula infectada. Neste projeto tivemos por objetivo caracterizar a interação, observada anteriormente no laboratório, da nucleoproteína viral $(\mathrm{N})$ com as proteínas PRMT5 e WDR77, que constituem o metilosomo celular. Obtivemos dados confirmando que essa interação ocorre através de nova coimunoprecipitação em células humanas; além de dados de interação in vitro dessas proteínas purificadas, a partir de sua expressão em bactérias. Demonstramos a co-localização dessas proteínas nos corpúsculos de inclusão intracelulares, formados durante a replicação viral através de microscopias de imunofluorescência e confocal. Com a consolidação do dado de interação, utilizamos siRNAs para PRMT5 e não observamos impacto na replicação viral. Como contraponto, testamos o efeito do aumento da expressão de PRMT5 utilizando vetor de expressão eucariótica e também não encontramos efeito sobre a replicação viral. Buscamos então evidência da importância funcional dessa interação, verificando se a própria $\mathrm{N}$ não seria alvo de metilação por PRMT5. Obtivemos resultados de que ocorre metilação em $\mathrm{N}$ tanto em resíduos de argininas como de lisinas, através de reatividade com anticorpos específicos para essas modificações, e análise por espectrometria de massas. Esses resíduos estão localizados em posições de $\mathrm{N}$ envolvidas na interação com o RNA viral e com a fosfoproteína viral, indicando significado funcional. Com essa evidência testamos o efeito de inibidores de metilação em argininas e lisinas, e de um inibidor de demetilação, na replicação viral. Obtivemos efeito inibitório significativo, acima de 70\%, da replicação do HRSV com um dos inibidores de metilação de lisina, UNC0646. Esses dados indicam que a interação Nmetilossomo tem potencial para ser explorada como alvo terapêutico no desenvolvimento de antivirais contra HRSV.

Palavras-chave: Vírus Respiratório Sincicial Humano. Metilossomo. PRMT5. Nucleoproteína. Interação célula-vírus 


\begin{abstract}
OGAWA, J. K. Characterization of humam respiratory syncytial virus nucleoprotein and methylosome interaction. 2016. 86 f. Disertation (Master in Microbiology) - Instituto de Ciências Biomédicas, Universidade de São Paulo, São Paulo, 2016.

The Human respiratory syncytial virus (HRSV) is one of the most important pathogens of the respiratory tract. This virus causes respiratory disease in newborns, babies, children and immunocompromised patients, and so far there is no vaccine approved or an antiviral effective and affordable cost, available for large-scale use. The HRSV genome encodes 11 proteins being fundamental to understand host-pathogen relationship, characterize their interactions in the infected cell. In this project we had as objective to characterize the interaction observed previously in the laboratory of viral nucleoprotein (N) with PRMT5 and WDR77 proteins that constitute the cell methylosome. We obtained confirmation that this interaction occurs with new coimunoprecipitation data in human cells, and in vitro interaction of these proteins purified from expression in bacteria. We also demonstrated the co-location of these proteins in intracellular inclusion bodies, formed during viral replication, by immunofluorescence and confocal microscopy. With the consolidation of interaction data, we did experiments with siRNAs against PRMT5 and not observed impact on viral replication. As a counterpoint, we tested the effect of the increased expression, using a eukaryotic PRMT5 expression vector, and also did not find effect on viral replication. We seek so evidence of functional importance of this interaction by checking if the own N would not be subjected to methylation by PRMT5. Our results show that methylation occurs in both arginine and lysine residues, through reactivity with antibodies specific to these modifications, and analysis by mass spectrometry. These residues are located in $\mathrm{N}$ positions involved in interaction with the viral RNA and viral phosphoprotein, indicating functional meaning. With this evidence, we tested the effect of arginine and lysine methylation and demethylation inhibitors in viral replication. We obtained significant inhibitory effect, above $70 \%$, on HRSV replication with a lysine methylation inhibitor, UNC0646. These data indicate that Nmetilossome interaction has the potential to be exploited as a therapeutic target in developing antiviral drugs against HRSV.
\end{abstract}

Keywords: Human respiratory syncytial virus. Methylossome. PRMT5. Nucleoprotein. Virus-cell interaction. 


\section{LISTA DE ILUSTRAÇÕES}

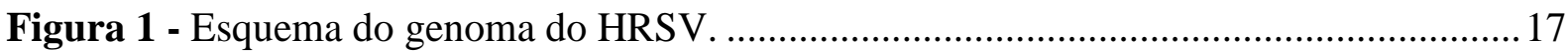

Figura 2 - Esquema da estrutura viral e suas proteínas. ..................................................... 18

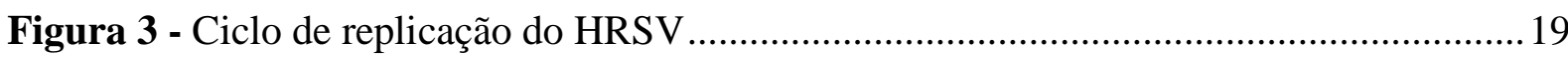

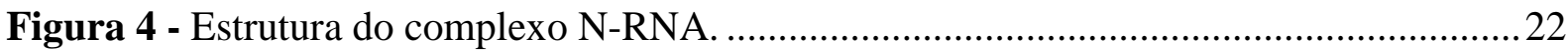

Figura 5 - Estrutura do complexo PRMT5-MEP50 ......................................................... 24

Figura 6 - Co-imunoprecipitação de N com WDR77 em células Hep-2 infectadas ................ 36

Figura 7 - Análise da interação entre WDR77 e N................................................................. 37

Figura 8 - Co-transformação com pGEX-PRMT5 + pET-WDR77 ……............................... 38

Figura 9 - Gel não desnaturante para análise da formação do metilossomo in bacteria. ........ 39

Figura 10 - Western Blottings do metilossomo formado in bacteria. .................................... 39

Figura 11 - Western Blottings da interação das proteínas do metilossomo com N................. 40

Figura 12 - Gel corado com Coomassie Blue da interação entre $\mathrm{N}$ e o metilossomo............. 40

Figura 13 - Western Blottings da interação das proteínas do metilossomo com a N..............41

Figura 14 - Imunofluorescênia das células BRST7 transfectadas com minigenoma..............42

Figura 15 - Co-localização N-PRMT5 com transfecção...................................................... 43

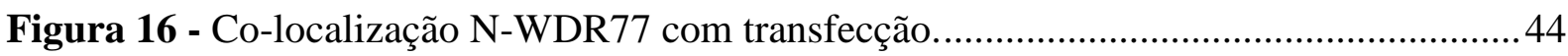

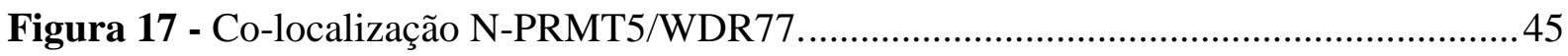

Figura 18 - Co-localização da PRMT5 e N por imunofluorescência confocal. ....................... 46

Figura 19 - Co-localização da WDR77 e N por imunofluorescência confocal........................47

Figura 20 - Co-localização da WDR77, PRMT5 e N por imunofluorescência confocal........ 48

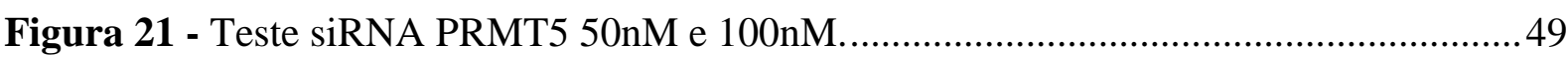

Figura 22 - Efeito do siRNA PRMT5 na replicação viral.................................................... 49

Figura 23 - Superexpressão das proteínas celulares e seu efeito na replicação viral. ..............50

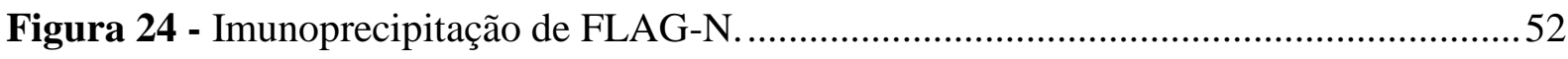

Figura 25 - Detecção de metilação em FLAG-N. ................................................................52

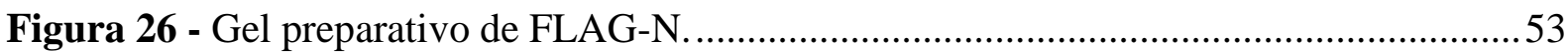

Figura 27 - Imagem de um detalhe da estrutura 3D da proteína N com indicação das posições metiladas próximas ao sítio de interação com $\mathrm{P}$.

Figura 28 - Imagem da estrutura 3D da proteína N com indicação das posições metiladas próximas ao domínio de ligação ao RNA 
Figura 29 - Imagem da estrutura 3D da proteína N com indicação das posições metiladas...56

Figura 30 - Analise da metilação em lisina por western blotting. ........................................57

Figura 31 - Imunofluorescência da lisina metilada em célula não infectada. .........................58

Figura 32 - Imunofluorescência da co-localização de lisina metilada e N.............................59

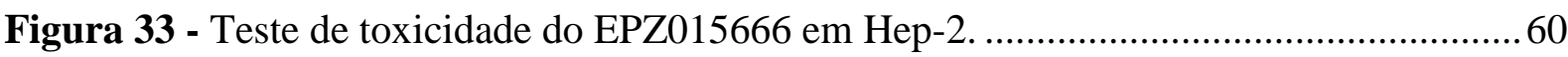

Figura 34 - Teste de toxicidade do EPZ015666 em HEK293T..............................................61

Figura 35 - Efeito do inibidor de metilação em arginina na infecção. ...................................61

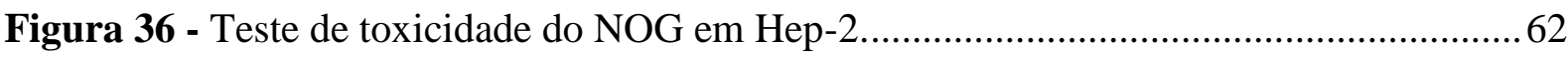

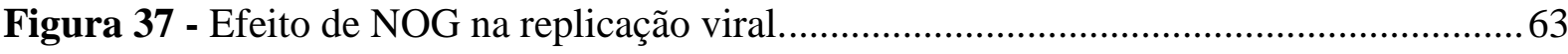

Figura 38 - Teste de toxicidade do duplo inibidor em Hep-2 ................................................64

Figura 39 - Teste de toxicidade do duplo inibidor em HEK293T..........................................64

Figura 40 - Efeito da dupla inibição de metilação em arginina na replicação viral. ................65

Figura 41 - Teste de toxicicidade dos inibidores de metilação em lisina em Hep-2 e

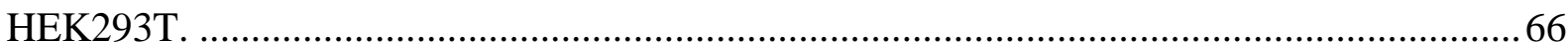

Figura 42 - Efeito dos inibidores de metilação em lisina na proteína P.................................67

Figura 43 - Efeito dos inibidores de metilação em lisina na expressão da proteína P. ...........67

Figura 44 - Efeito dos inibidores de metilação em lisina na expressão das proteínas G e N..68

Figura 45 - Potencial interferência da metilação na ligação de N ao RNA..............................76 


\section{LISTA DE TABELAS}

Tabela 1. Análise de FLAG-N por espectrometria de massas..............................................56

Tabela 2. Análise da proteína $\mathrm{N}$ do vírus ultracentrifugado por espectrometria de massas 


\section{LISTA DE ABREVIATURAS E SIGLAS}

2-OG - 2-oxoglutarato

AdoMet - S-adenosilmetionina

ATP - Adenosina trifosfato

BSA - Albumina bovina

cDNA - DNA complementar

DEPC - Dietilpirocarbonato

DTT - DL-Dithiothreitol

DNA - ácido desoxirribonucleico

EDTA - ácido etilenodiaminotetracético

$\mathrm{Fe}(\mathrm{II})$ - Óxido de ferro

$\mathrm{GE}$ - gene end

GS - gene start

GST - Glutathione S-transferase

h - Hora

HRSV - Vírus respiratório sincicial humano

Hsp70 - Heat shock protein 70

ICTV - International Committee on Taxonomy of Viruses

IRES - internal ribosomal entry site

IPTG - Isopropil-beta-D-tiogalactopiranosídeo

JAK - Janus quinase

JmjC - Jumonji com domínio C

JMJD - Proteínas contendo domínio Jumonji

JMJD6 - Jumonji com domínio C contendo a proteína 6

LB - Luria-Bertani

LTR - long terminal repeat

MEM - Minimum Essential Medium

Mep50 - methylosome protein 50

Min - minuto

mRNAs - RNA mensageiro

NOG - N-oxalilglicina 
PEI - polyethyleneimine

PRMT5- Proteina arginina metil transferase-5

PRMT - Proteina arginina metil transferase

RNA - Ácido Ribonucléico

$\mathrm{Rpm}$ - rotações por minuto

siRNA - small interfering RNA

SFB - Soro Fetal Bovino

SV40 - Simian vacuolating virus 40

T.A. - Temperatura ambiente

WDR77 - proteína que contém 77 repetições de WD 


\section{SUMÁRIO}

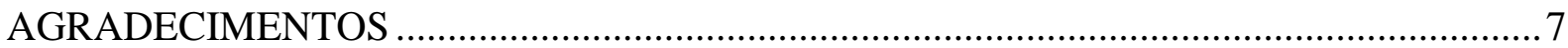

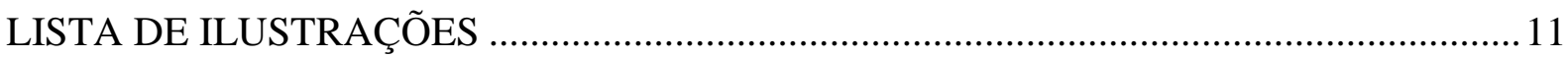

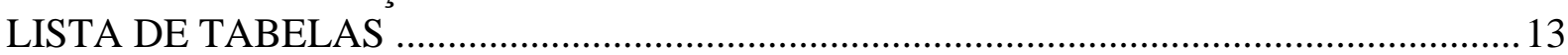

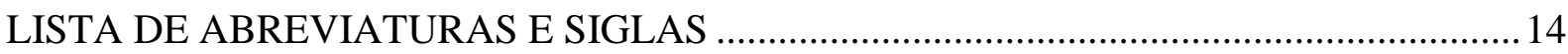

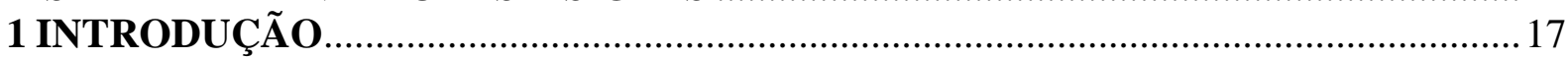

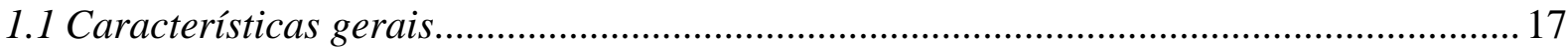

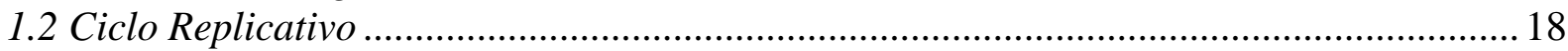

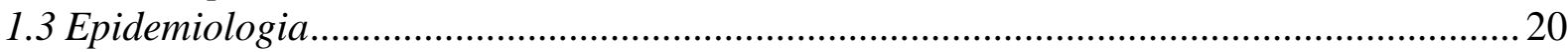

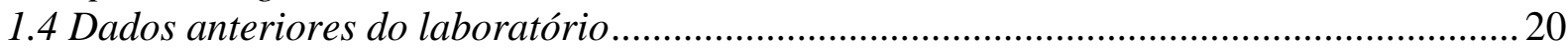

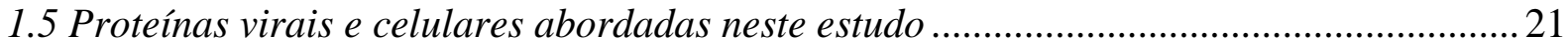

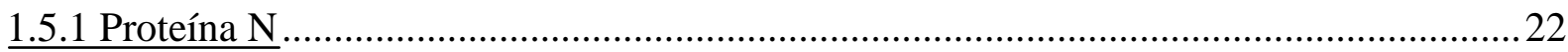

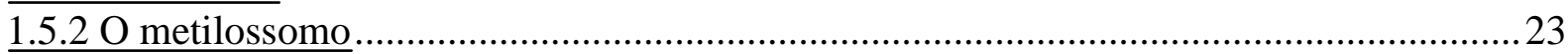

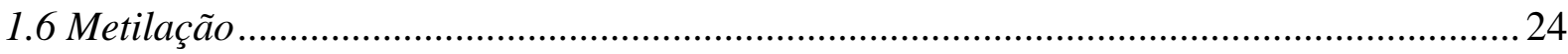

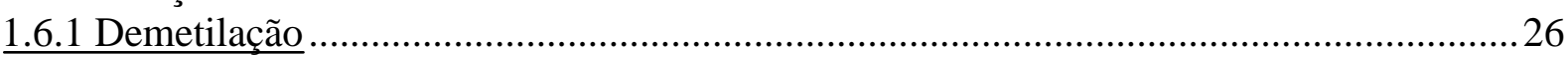

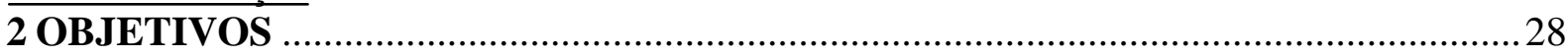

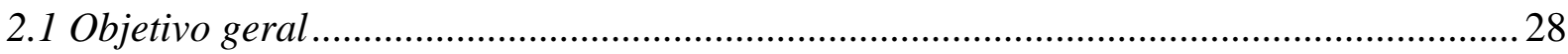

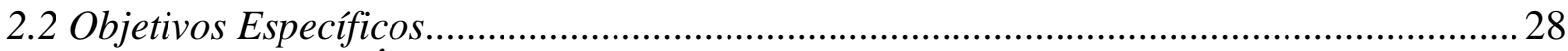

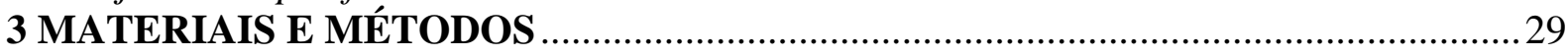

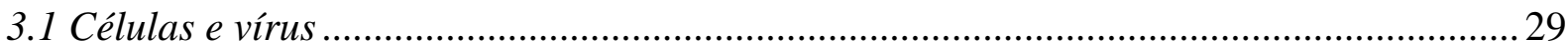

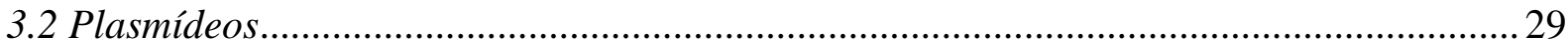

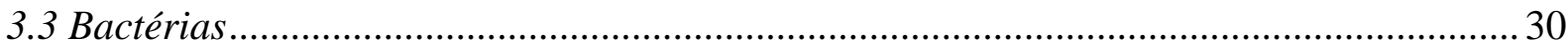

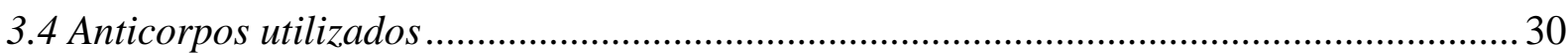

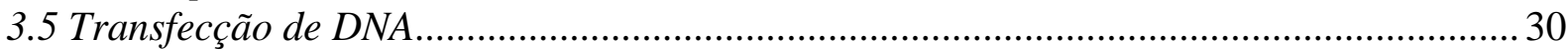

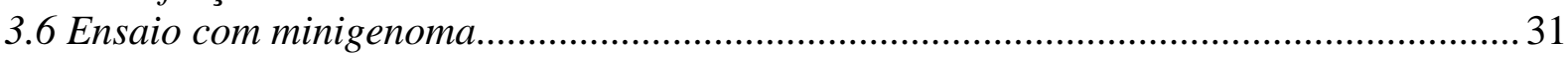

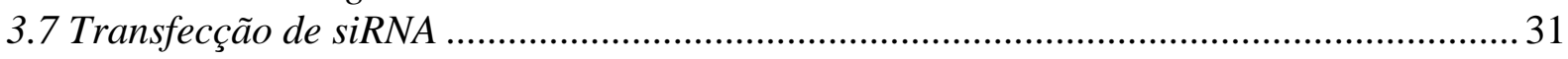

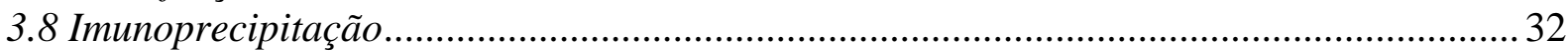

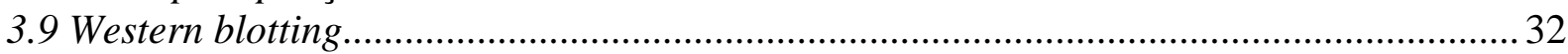

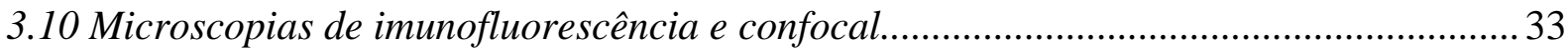

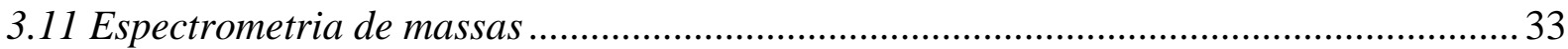

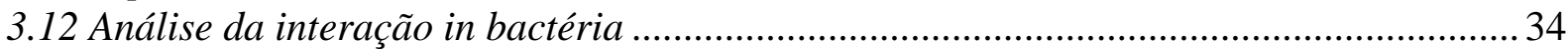

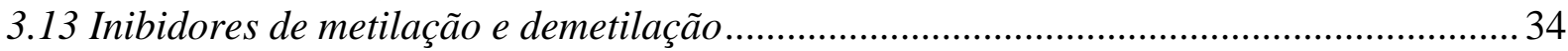

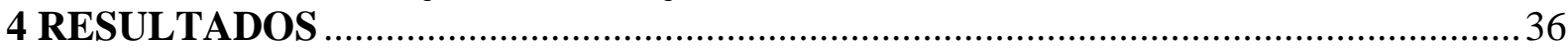

4.1 Confirmação da interação entre o metilossomo e a proteína $N$ expressa por infecção. ... 36

4.2 Análise da interação N-WDR77/PRMT5 com proteínas expressas em bactérias............... 37

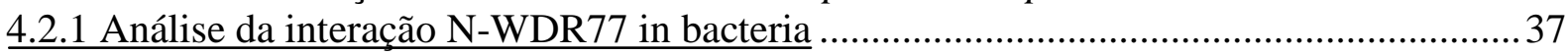

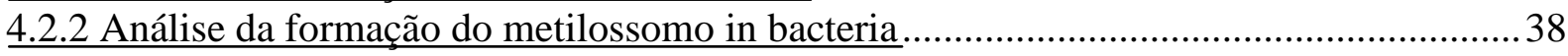

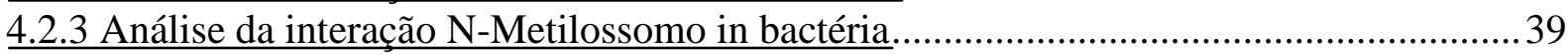

4.3 Co-localização intracelular entre $N$ e PRMT5 em células transfectadas com minigenoma

4.4 Co-localização entre metilossomo e $N$ detectada por imunofluorescência em células

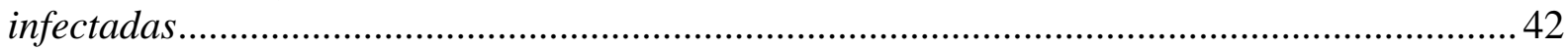

4.5 Inibição da PRMT5 por si RNA e seu efeito na replicação viral .......................................... 48

4.6 Superexpressão da PRMT5 elou WDR77 e seu efeito na replicação viral ......................... 50

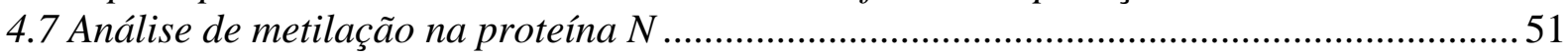

4.7.1 Análise de metilação na proteína FLAG-N expressa por transfecção ..............................51 
4.7.2 Análise de metilação da proteína N viral ..........................................................................55

4.8 Efeito de inibidores de metilação e demetilação na replicação viral ..................................59

4.8.1 Inibidor de metilação em arginina pela PRMT5 ….....................................................6 60

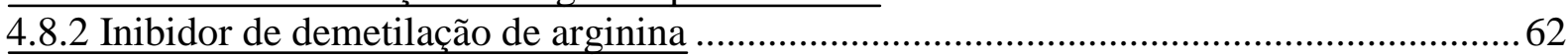

4.8.3 Inibidores de metilação e demetilação de arginina em conjunto .....................................63

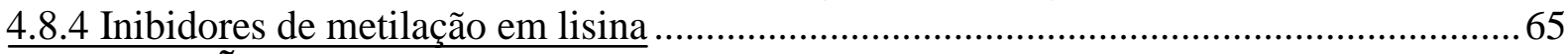

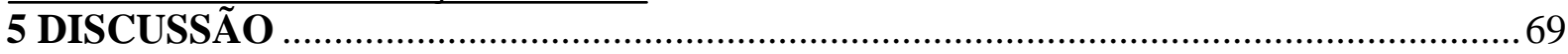

5.1 Interação $N$-WDR77/PRMT5 com proteínas expressas em bactérias.................................. 69

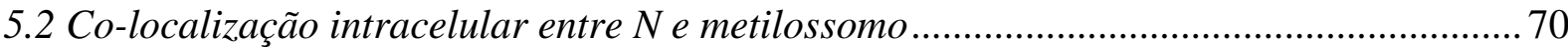

5.3 Inibição da PRMT5 por si RNA e seu efeito na replicação viral ....................................... 71

5.4 Aumento da expressão do metilossomo e seu efeito na replicação viral ............................ 72

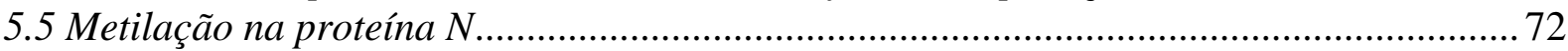

5.6 Inibidores de metilação e demetilação em arginina e seu efeito na replicação viral........ 77

5.7 Inibidores de metilação em lisina e seu efeito na replicação viral ......................................78

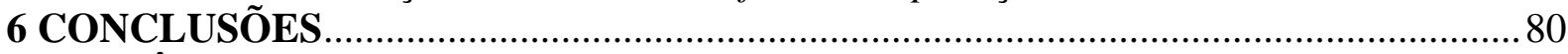

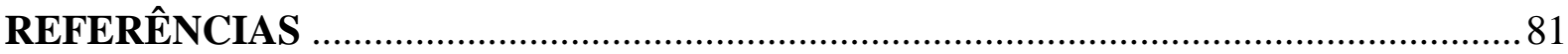




\section{INTRODUÇÃO}

\subsection{Características gerais}

O vírus respiratório sincicial humano (HRSV) é um vírus de RNA não segmentado de polaridade negativa. Pertence à ordem Mononegavirales, família Paramxoviridae, subfamília Pneumovirinae, gênero Pneumovirus, segundo as normas do International Committee on Taxonomy of Viruses (ICTV) (COLLINS; MELERO, 2011). O vírus foi isolado pela primeira vez em 1955 de um chimpanzé em cativeiro que apresentava sintomatologia semelhante ao resfriado comum, e posteriormente isolado de humanos em 1957. (BLOUNT, 1956; CHANOCK, 1957).

Este vírus é o patógeno do trato respiratório inferior mais importante em recémnascidos (LOZANO et al., 2012). Existem dois grupos antigênicos, A (HRSV-A) e B (HRSV$\mathrm{B})$, e muitas evidências indicam que as diferenças entre esses grupos contribuem para as reinfecções que ocorrem ao longo da vida de um indivíduo (YUI et al., 2014). Até o presente não há droga efetiva ou vacina aprovada contra o HRSV (RAMEIX-WELTI et al., 2014).

O genoma do HRSV (Figura 1) possui 15,2 Kb e 10 genes: NS1, NS2 (não estruturais), N (nucleocapsídeo), P (fosfoproteína), M (proteína de matriz), SH (pequena glicoproteína transmembrana), F (proteína de fusão), G (anti-receptor), M2 (regulação da transcrição e replicação) e L (principal subunidade da RNA polimerase), que são transcritos em 10 mRNAs, sendo traduzido um polipeptídeo para cada gene, exceto para M2 que possui duas ORFs (open reading frames) que se sobrepõe, dando origem às proteínas M2-1 e M2-2. Com isso, o HRSV possui 11 proteínas distintas (COLLINS; MELERO, 2011).

Figura 1 - Esquema do genoma do HRSV.

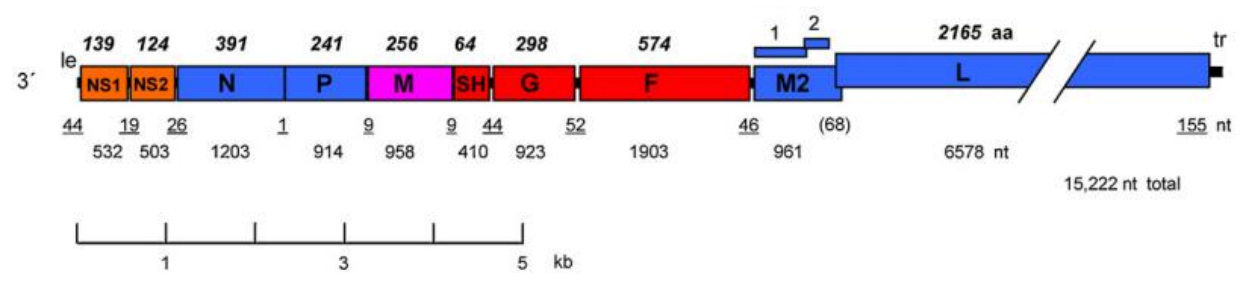

Fonte: Collins e Melero (2011) 
As proteínas NS1 e NS2 não estão presentes no vírion maduro (Figura 2) e tem papel no bloqueio das vias de resposta e produção de interferon. F, G e SH são glicoproteínas transmembrânicas do envelope, segundo Pretel; Camporeale; De Prat-Gay (2013), onde F é a responsável pela penetração do vírus na célula, assim como sua fusão com as células vizinhas. A proteína $\mathrm{G}$ tem papel importante na adsorção do vírus à célula. Tanto $\mathrm{F}$ quanto a $\mathrm{G}$ se ligam a glicosaminoglicanos, passo necessário para uma infecção eficiente (COLLINS; MELERO, 2011). Na superfície interna da membrana está a proteína de matriz, que é um componente estrutural do vírus e tem papel importante na montagem do vírion ao inibir a transcrição e formar uma ponte entre o nucleocapsídeo viral e o envelope (MITRA et al., 2012; RODRÍGUEZ et al., 2004). M2-2 é uma proteína pequena que se acumula durante a infecção e tem papel na transição da síntese de RNA genômico para a sua transcrição (COLLINS; MELERO, 2011). O complexo helicoidal ribonucleoproteico (nucleocapsídeo) é formado pela proteína N e o RNA viral, que juntamente com a RNA polimerase, composta pela L associada aos cofatores P e M2-1, constituem o nucleocapsídeo funcional (BHELLA et al., 2002).

Figura 2 - Esquema da estrutura viral e suas proteínas.

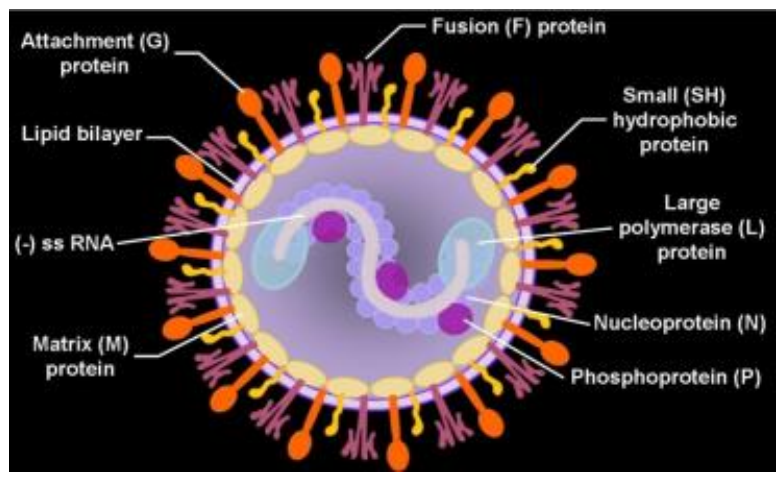

Fonte: Rega Institute for Medical Research.

\subsection{Ciclo replicativo}

A infecção de células alvo, como células epiteliais das vias aéreas, começa com a adsorção auxiliada pela proteína $\mathrm{G}$, que interage com proteoglicanos de heparan sulfato e glicosaminoglicanos condroitina sulfato B (GAG). Depois desta interação, que ajuda o vírus a se aproximar a membrana da célula a ser infectada, a proteína $\mathrm{F}$ se liga ao seu receptor, nucleolina. A entrada do HRSV tem sido descrita em microdomínios da membrana particularmente ricas em colesterol. A fusão do HRSV na membrana da célula hospedeira 
depende da interação entre a $\mathrm{F}$ e a proteína $\mathrm{G}$ com o receptor e o rearranjo dos filamentos de actina próximas aos microdomínios de colesterol. A fusão do envelope viral com a membrana libera o nucleocapsídeo no citoplasma e ocorre a fosforilação da proteína P (BOHMWALD et al., 2016). A infecção pelo HRSV resulta na formação de corpúsculos de inclusão citoplasmáticos, tendo sido neles demonstrada a presença das proteínas $\mathrm{N}, \mathrm{P}, \mathrm{M} 2-1$ e L (CARROMEU et al., 2007; OLIVEIRA et al., 2013). O complexo L-P é responsável pelo reconhecimento do promotor, síntese do RNA, capping, metilação da região 5' do mRNA e a poliadenilação da região 3'. A proteína L é capaz de reconhecer o sítio $\operatorname{TrC}$ na região 3' do antigenoma para gerar novos genomas virais. O novo RNA é imediatamente encapsulado pela proteína N (COWTON; MCGIVERN; FEANS, 2016). Em seguida a proteína M executa sua função de juntar o complexo RNP ao envelope viral. Já se sabe que a proteína M se associa com o RNP através da proteína M2-1, e se liga a parte interna da membrana e a cauda citoplasmática da proteína $\mathrm{G}$ para fazer a montagem do vírus (MITRA et al., 2012). A figura 3 mostra um esquema do ciclo de replicação do HRSV.

Figura 3 - Ciclo de replicação do HRSV

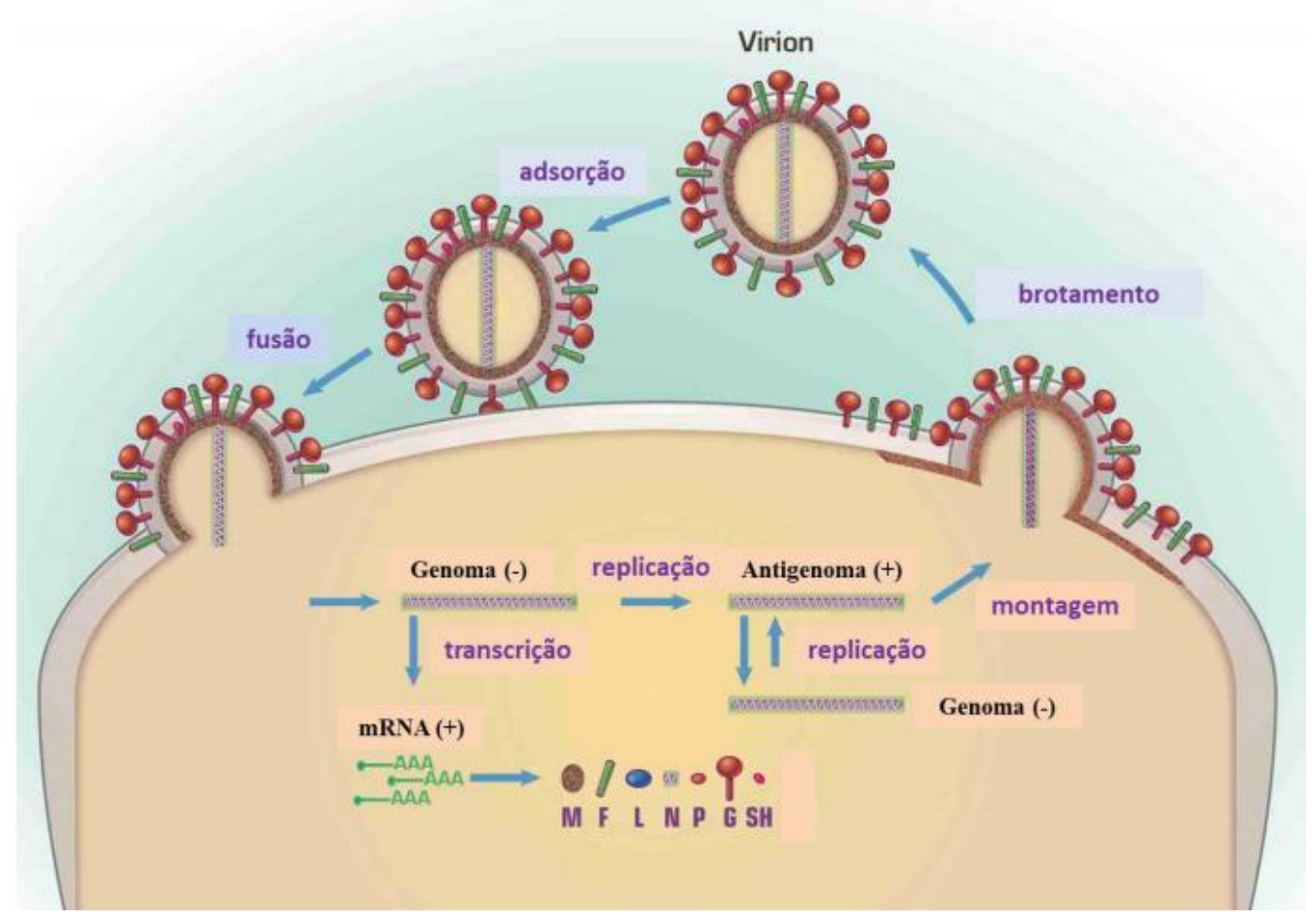

O esquema mostra o ciclo de replicação do HRSV desde a adsorção até o brotamento. Fonte: Dr. JF Éleouët não publicado, modificado. 


\subsection{Epidemiologia}

As infecções respiratórias virais representam um importante problema de saúde pública pela sua ocorrência mundial, facilidade de disseminação na comunidade e relativa morbidade e mortalidade. Em pacientes pediátricos, as infecções por vírus respiratórios são as principais causas de morbidade, estas infecções são responsáveis por 1 a 3\% da mortalidade entre crianças menores de cinco anos de idade em países industrializados e de 10 a $15 \%$ em países em desenvolvimento. Estima-se que anualmente morrem aproximadamente 5 milhões de crianças por infecções respiratórias de origem viral (MOREIRA, 2015). Detecções do HRSV são conhecidas por serem dependentes da idade, com cerca de $60 \%$ das crianças infectadas até o primeiro ano de vida e praticamente todas as crianças infectadas até o segundo ano. Poucas detecções são feitas em crianças mais velhas e adultos (HOGAN et al., 2016).

Em 2005 pelo menos 33,8 milhões de episódios de infecção respiratória aguda inferior (ALRI) associados ao HRSV foram detectados no mundo em crianças com menos de 5 anos, com a incidência em países em desenvolvimento sendo o dobro do que em países desenvolvidos. Esta estimativa representa cerca de $22 \%$ de todos os episódios de ALRI em crianças pequenas. Uma proporção substancial da morbidade associada ao HRSV ocorre no primeiro ano de vida, com a incidência em crianças menores de 5 anos duas ou três vezes maior do que em crianças de 5 anos. Também verificou-se que cerca de 3,4 milhões de crianças desenvolveram ALRI severa devido ao vírus e tiveram que ser hospitalizadas e 66.000 a 199.000 crianças com menos de 5 anos faleceram devido a ARLI associada ao HRSV, sendo 99\% destes casos em países em desenvolvimento (NAIR et al., 2010). Em 2010, 234.000 mortes de crianças ocorreram devido a esse vírus. Além disso, o HRSV também é um importante patógeno em idosos (LOZANO et al., 2012).

\subsection{Dados anteriores do laboratório}

É fundamental para entender a relação do HRSV com o hospedeiro, caracterizar as interações entre as suas proteínas e componentes celulares. Em trabalho anterior do laboratório essa questão foi abordada para as proteínas N, P e M. Os genes virais foram otimizados para a expressão eficiente em células de mamíferos e foram sub-clonados, de modo a ter essas proteínas expressas em fusão com o peptídeo FLAG (SIMABUCO et al, 
2009; SIMABUCO, 2009; TAMURA 2009). Isso possibilitou utilizar a técnica de coimunoprecipitação das proteínas celulares associadas a essas proteínas virais com anticorpo anti-FLAG, seguida de espectrometria de massas. Foram selecionadas as proteínas identificadas que tiveram maior porcentagem de cobertura, para análises confirmatórias por co-imunoprecipitação seguida de western blotting com anticorpos específicos.

As interações foram primeiro confirmadas utilizando transfecção com os vetores de expressão dos genes virais otimizados para expressão em células humanas, seguidas de imunoprecipitação com anti-FLAG, e detecção com anticorpos contra as proteínas celulares. A segunda abordagem foi imunoprecipitar extratos de células infectadas pelo vírus com os anticorpos contra as proteínas celulares identificadas, seguindo-se a detecção com anticorpos contra as proteínas virais. As interações confirmadas mostraram que a proteína $\mathrm{N}$ interage com a proteína do choque térmico Hsp70 e com as proteínas do metilossomo WDR77 e PRMT5; P interage com Hsp70 e com Tropomiosina; e M com as proteínas Nucleofosmina e Tropomiosina (OLIVEIRA et al., 2013).

Neste trabalho nosso enfoque foi na caracterização da interação entre a proteína $\mathrm{N}$ e o metilossomo. Devemos ressaltar que esse trabalho passou a integrar um projeto maior de cooperação entre os grupos do Dr. Ventura e do Dr. Jean-François Eléouet (Institut National de la Rechérche Agronomique, unidade de Jouy-en-Josas, França) a partir de 2013 (acordo FAPESP-ANR), com o objetivo de caracterizar as interações HRSV-célula de forma mais abrangente.

\subsection{Proteínas virais e celulares abordadas neste estudo}

A interação entre as proteínas do metilossomo e a proteína $\mathrm{N}$ do HRSV é atraente pelo fato de que $\mathrm{N}$ interage fortemente com o RNA viral, a deduzir pela resolução da estrutura obtida em bactérias (TAWAR et al., 2009). Fica então a questão de como nessa estrutura seria possível a intervenção do complexo RNA polimerase RNA dependente constituído pelas proteínas virais L e P para transcrever e replicar o genoma. A metilação, tanto em argininas como em lisinas tem o potencial de interferir na dinâmica da interação N-RNA, tanto pela modificação das proteínas virais envolvidas, quanto de proteínas celulares associadas ainda não identificadas. 


\section{$\underline{1.5 .1 \text { Proteína N }}$}

A proteína N do HRSV é composta por 391 aminoácidos e o complexo que forma com o RNA genômico do vírus (nucleocaspsídeo) está presente em todos os membros da ordem Mononegavirales. Este é utilizado como molde para a síntese de RNA pelo complexo polimerase viral, já que o RNA é protegido do ataque de ribonucleases, e o nucleocapsídeo mascara o genoma para impedir a produção de interferons pela célula hospedeira (MURPHY et al., 2003; OLIVEIRA et al., 2013; TAWAR et al., 2009). O nucleocapsídeo é uma hélice flexível de tamanho variável, recém-caracterizada como tendo passo à esquerda, com um número não definido de unidades de proteínas N por volta (BAKKER et al., 2013).

A resolução da estrutura de $\mathrm{N}$ expressa em bactérias associada a RNA, foi obtida como um anel composto por 10 proteínas $\mathrm{N}$, onde o RNA passa em volta do anel, como um cinto (Figura 4). Cada subunidade $\mathrm{N}$ interage com 7 ribonucleotídeos, resultando numa cadeia de RNA com 70 bases no total. N possui domínios amino e carboxi terminal, conectados por uma região flexível, cada um possui extensões chamadas de $\mathrm{N}$-arm e $\mathrm{C}$-arm, respectivamente. O anel é estabilizado pelo RNA e por uma "cadeia N" resultante de interação do N-arm (resíduos 1 a 35), enquanto que o C-arm do C terminal se localiza nos espaços entre os anéis na estrutura helicoidal (resíduos 361 a 391) (TAWAR et al., 2009).

Figura 4 - Estrutura do complexo N-RNA.

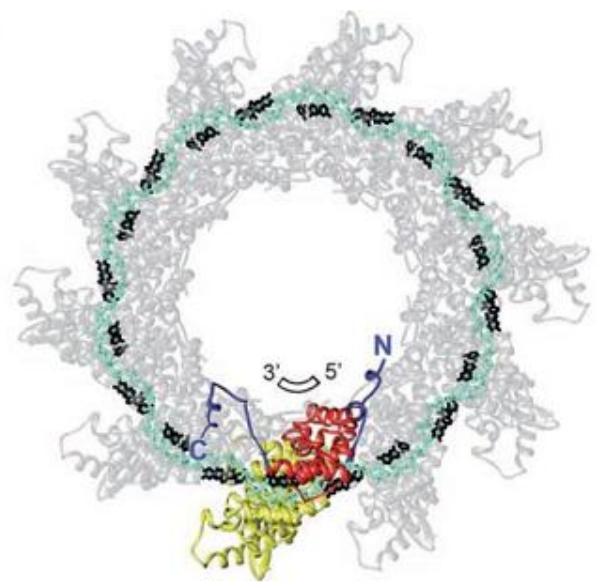

Há uma subunidade $\mathrm{N}$ destacada: em amarelo ( $\mathrm{C}$ terminal), vermelho ( $\mathrm{N}$ terminal) e azul ( $\mathrm{N}$ e C-arms). O RNA está representado em azul claro e preto ao redor do anel. Fonte: Tawar et al. 2009.

$\mathrm{N}$ interage com a proteína $\mathrm{P}$, estando o domínio C-terminal de $\mathrm{P}$ (os últimos nove resíduos 161-241) envolvido nessa interação (TRAN et al., 2007). Em estudo mais recente, o 
domínio da proteína $\mathrm{N}$ (aminoácidos 31 a 252) ao qual $\mathrm{P}$ se liga foi caracterizado, sendo importante frisar que P também interage com L mediando sua interação com o nucleocapsídeo (GALLOUX et al., 2012).

\section{$\underline{1.5 .2 \mathrm{O} \text { metilossomo }}$}

A família das proteínas arginina metil-transferase (PRMT) faz parte da maior classe de enzimas metil-transferase S-adenosilmetionina (AdoMet)-dependente. Até o momento foram identificadas onze PRMTs humanas, que estão subdivididas em quatro tipos: tipo I (PRMT1, 2, 3, 4, 6 e 8), tipo II (PRMT5), tipo III (PRMT7) e tipo IV (PRMTS 9, 10 e 11), baseado no padrão de metilação da arginina. Todas as PRMTs possuem o domínio catalítico altamente conservado e muitas possuem domínios adicionais que modulam a atividade e especificidade (ANTONYSAMY, 2012). Esta família de enzimas possui um papel importante em diversas funções celulares, que vai desde a transcrição e processamento do RNA até a sinalização, diferenciação, apoptose e tumorigênese (HO et al., 2013). PRMT5 foi originalmente identificada como uma proteína que se liga à JAK-quinase e posteriormente foi descoberto que possui atividade metiltransferase em resíduos de arginina (GREENBLATT; LIU; NIMER, 2016). A PRMT5 se liga a muitos cofatores diferentes, entre eles, RioK1, pICLn e MEP50 (WDR77), sendo este último o cofator mais comum e mais provável de se encontrar com complexos com PRMT5 in vivo (HO et al., 2013). O complexo com a WDR77 forma um hetero octâmero (Figura 5) com quatro subunidades de cada proteína que parece ser o núcleo estrutural que interage com as outras proteínas (ANTONYSAMY, 2012).

Foi demonstrado que a PRMT5 participa dos processos de biogênese do ribossomo, montagem do complexo de Golgi, diferenciação celular, regula a transcrição por metilação de histonas e reduz a transcrição de genes ribossomais específicos (GREENBLATT, et al., 2016; KARKHANIS et al., 2011). Sabe-se que a PRMT5 é a mais frequente enzima do tipo II nas células de mamíferos e é capaz de catalisar a transferência de até dois grupos metil para resíduos de arginina, formando $\omega$-NG-monometil arginina e $\omega$-NG-dimetil arginina simétrica (CHAN-PENEBRE et al., 2015; GREENBLATT et al., 2016). Acredita-se que é a principal enzima para dimetilação simétrica (DUNCAN et al., 2015). 
Figura 5 - Estrutura do complexo PRMT5-MEP50

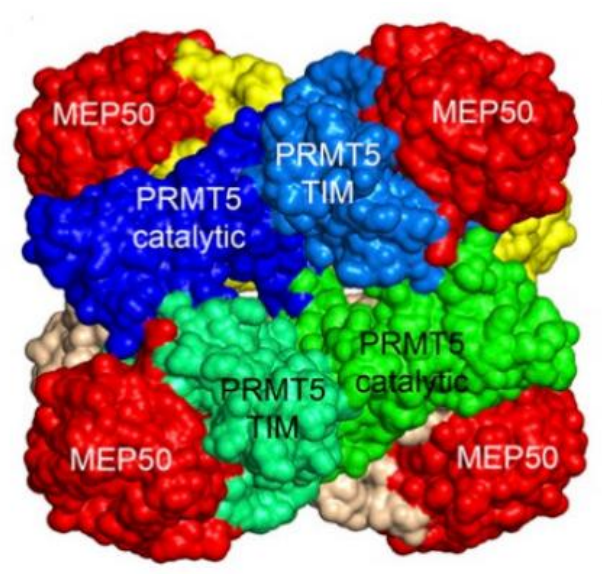

Está apresentada a estrutura do octâmero do metilossomo, onde 4 unidades MEP50 (WDR77) em vermelho correspondem aos sítios de interação com a proteína alvo, e as outros 4 correspondem aos sítios catalíticos, PRMT5, em azul e verde. Fonte: Antonysammy et al. (2012)

\subsection{Metilação}

Uma das mais eficientes e dinâmicas evoluções para expandir o código genético é a modificação pós traducional de proteínas. Estas modificações podem alterar as propriedades físico-químicas das cadeias laterais dos aminoácidos, afetando significativamente a estrutura e função de diversas proteínas (AZEVEDO; SAIARDI, 2015). O papel da fosforilação na regulação pós traducional já foi extensamente estudado, mas recentemente a importância de outros tipos de modificações em proteínas, incluindo acetilação e metilação, começaram a ser reconhecidas (LEE; STALLCUP, 2009). Nos últimos anos ficou claro que grupos metil ficam lado a lado com grupos fosfato como maiores elementos controladores das funções das proteínas. Uma grande variedade de reações de metilação (e em alguns casos, demetilações), ocorrem nas cadeias laterais de vários resíduos de aminoácidos e nas porções $\mathrm{C}$ e $\mathrm{N}$ terminal das proteínas (BEDFORD; CLARKE, 2009). A metilação é uma das mais abundantes modificações em proteínas. Por exemplo, cerca de $2 \%$ dos resíduos de argininas em extrato total de proteínas de fígado de camundongo foram encontradas dimetiladas (LEE; STALLCUP, 2009).

Lisina e arginina, aminoácidos estruturalmente semelhantes, são $\alpha$-aminoácidos essenciais. Lisina contém uma longa e flexível cadeia lateral contendo um grupo $\varepsilon$-amino terminal (grupo amino primário). Sob condições fisiológicas normais, o amino primário possui carga positiva. As argininas, por outro lado, possuem um grupo guanidina carregado 
positivamente. Tanto a lisina quanto a arginina são propensos a se localizarem na região hidrofílica externa da superfície da proteína, com os grupos $\varepsilon$-amino terminal e guanidina, respectivamente, expostos (AZEVEDO; SAIARDI, 2015).

Metilação em arginina é uma modificação pós traducional comum em muitas proteínas nucleares de células eucarióticas (PAHLICH; ZAKARYAN; GEHRING, 2006). É uma abundante modificação covalente que regula diversos processos celulares, incluindo a transcrição, tradução, reparo de DNA e processamento do RNA (GREENBLATT; LIU; NIMER, 2016). A arginina é única em comparação com os outros aminoácidos, já que seu grupo guanidina possui cinco potencias doadores de hidrogênio, que estão posicionados em condições favoráveis para interação com aceptores biológicos (BEDFORD; CLARKE, 2009). A adição de cada grupo metil remove um potencial doador de hidrogênio, o que em parte aumenta o volume a hidrofobicidade mas, importantemente, não afeta a carga catiônica dos resíduos de arginina (BLEE; GRAY; BROOK, 2015). Tal modificação pode modular as suas interações e, portanto, regular suas funções fisiológicas (BEDFORD; CLARKE, 2009).

Inibidores de metilação têm sido utilizados com sucesso para verificar a ação da metilação em histonas, em proteínas relacionadas à doenças genéticas, seu papel em células cancerígenas e no processo da infecção viral em diferentes vírus (ALINARI et al., 2015; BENEDETTI et al., 2015; BLEE et al., 2015; CHAN-PENEBRE et al., 2015; DUONG et al., 2005; SMIL et al., 2015; SPANNHOFF et al., 2007; YOSHIMATSU et al., 2011). EPZ015666 é um inibidor da PRMT5 de primeira classe, com potente atividade celular ao verificar sua habilidade de inibir a dimetilação simétrica da arginina da SmD3 (pequena partícula de ribonucleoproteína, substrato da PRMT5), de maneira tempo/dose dependente (RIOUX et al., 2015). O composto interage diretamente com muitos resíduos envolvidos na ligação com peptídeos ou resíduos que parecem estar envolvidos com o mecanismo catalítico da transferência do grupo metil (CHAN-PENEBRE et al., 2015). Por isso o composto surgiu como a melhor combinação de baixa liberação no plasma e alta biodisponibilidade oral, que mantém potente ação antiproliferativa contra linhagens celulares de linfoma de células do manto. Além disso, EPZ015666 mostrou ser um inibidor extremamente potente para estudos in vitro (DUNCAN et al., 2015).

Metilação, dimetilação e trimetilação do grupo $\varepsilon$ em lisina são catalisados por proteínas lisina metiltransferase de modo S-adenosil-L-metionina (AdoMet) dependente. Bioquimicamente, AdoMet é o principal doador nas reações de metiltransferase e é o segundo substrato mais usado em reações, perdendo somente para o ATP. Esta frequência indica a 
importância da reação de metilação em diversas reações bioquímicas e vias metabólicas (HAMAMOTO; SALOURA; NAKAMURA, 2015). Apesar das metilações em lisinas terem sido extensamente estudadas em histonas, o estudo de metilação em proteínas não-histonas é recente, e tem crescido rapidamente (HE et al., 2012). A relativa liberdade na coordenação iônica e reatividade química do grupo amino primário coloca a lisina no papel principal de vários mecanismos de catálise de enzimas. (AZEVEDO; SAIARDI, 2015). Metilação em lisina está associada com ativação ou repressão gênica, dependendo do local e grau de metilação. Por exemplo, genes marcados pela metilação das histonas H3 em K9 ou K27, ou H4 em K20 são normalmente reprimidos, ao passo que genes associados com H3 metilada em K4 ou K36 são normalmente ativados (BIGGAR; LI, 2014). Assim como em histonas, a metilação de lisinas em proteínas não-histonas facilita a interação com substratos específicos para executarem sinalização e crosstalk entre a metilação de lisinas e outras modificações pós traducionais que também impactam as funções biológicas (ZHANG; HUANG; SHI, 2015).

\subsubsection{Demetilação}

Inicialmente achava-se que o grupo metil era estável em resíduos de arginina (Bedford; Clarke, 2009), por isso o único modo de reverter o efeito da metilação seria degradar a proteína e sintetizar uma nova proteína não metilada (BEDFORD, 2009; ESSE et al., 2013). Diversas lisinas demetilases já foram descritas, mas somente uma verdadeira arginina demetilase foi identificada até o presente: a Jumonji com domínio C (JmjC) contendo a proteína 6 (JMJD6) (LAWRENCE; CONDERINO; RIEDER, 2014). Tem sido reportado que as JMJD removem o grupo metil de histonas H3 através de atividade dependente de $\mathrm{Fe}(\mathrm{II}) / \alpha$-cetoglutarato (HAMADA et al., 2010). Esta enzima catalisa uma variedade de transformações químicas cruciais como o reparo de DNA e RNA por danos causados pela alcalinização, modificação estrutural de proteínas e síntese de vários metabólitos (KALLIRI; GRZYSKA; HAUSINGER, 2005). JMJD6 é uma enzima dependente de ferro ferroso Fe(II) e 2-oxoglutarato (2-OG), que catalisa a hidroxilação que resulta em produtos de álcoois estáveis e demetila o N-metil. Esta enzima tem papel na regulação epigenética ao catalisar tanto a demetilação simétrica quanto assimétrica em H3 (posição R2) e H4 (posição R3) (BÖTTGER et al., 2015).

N-oxalilglicina (NOG) é um análogo da $\alpha$-cetoglutarato e inibidor de enzimas com domínio JmjC que é conhecido por competir com o 2-OG de maneira dose dependente 
(KALLIRI, 2005; LAWRENCE, 2014). NOG se liga ao sitio ativo de maneira similar, mas não idêntica ao 2-OG, porém ele não age no ciclo catalítico (AL-QAHTANI et al., 2015). Já foi visto que o NOG inibiu a ação da JMJD6 na demetilação da RNA helicase, além de diminuir a síntese de proteínas e título viral de picornavírus (LAWRENCE; CONDERINO; RIEDER, 2014). 


\section{OBJETIVOS}

\subsection{Objetivo geral}

Nossos objetivos gerais são de confirmar a interação entre $\mathrm{N}$ e o metilossomo e testar se este tem papel funcional na replicação viral, além de verificar se a própria $\mathrm{N}$ é alvo de metilação e em caso positivo se a inibição desse fenômeno afeta a replicação viral.

\subsection{Objetivos específicos}

1 - Confirmar a interação entre N e o metilossomo (PRMT5/WDR77) por imunoprecipitação com anticorpo monoclonal anti $\mathrm{N}$.

2 - Analisar a interação N - WDR77 e/ou PRMT5 com proteínas expressas in bacteria.

3 - Verificar se há co-localização intracelular entre N e PRMT5/WDR77, em corpúsculos de inclusão utilizando o ensaio de minigenoma e em células infectadas, por microscopia de imunofluorescência e confocal.

4 - Analisar o efeito da inibição de PRMT5 por siRNA, e da superexpressão de PRMT5 e WDR77 por transfecção de vetores de expressão eucariota dessas proteínas, na replicação viral.

5 - Analisar se há metilação de resíduos de arginina e lisina em N, tanto na proteína expressa por transfecção quanto na infecção viral, utilizando anticorpos e espectrometria de massas.

6 - Verificar o efeito de inibidores de metilação em arginina e lisina, e demetilação de arginina, na replicação viral. 


\section{MATERIAIS E MÉTODOS}

\subsection{Células e vírus}

HEp-2 são células humanas isoladas originalmente de carcinoma epitelial de laringe. A infecção e o efeito citopático do HRSV A2 são muito bem caracterizados nessa célula. As células HEK293T são provenientes de rim humano, apresentam um fenótipo indiferenciado sendo células altamente transfectáveis, e expressam o antígeno T do vírus SV40. As células BSRT7/5 são derivadas de células BHK-21 (fibroblastos de rim de hamsters da espécie Mesocricetus auratus, clone BSRT7/5) que expressam constitutivamente a RNA polimerase do fago T7.

Foi utilizado o vírus HRSV cepa A2, amplificado a partir da infecção de células Hep-2 em meio MEM $1 \%$ de SFB. Após 48 hs, as células foram coletadas por raspagem e passadas em Dounce 10 vezes para quebra da membrana citoplasmática, no gelo, em PBS $30 \%$ de sacarose, feita sedimentação de estruturas celulares a baixa velocidade, e o sobrenadante com os vírus guardado em freezer $-80{ }^{\circ} \mathrm{C}$. Para a titulação do vírus, células Hep-2 foram plaqueadas em multiwell de 96 poços e infectadas com diluição seriada do estoque viral $\left(10^{-6}\right.$ a $10^{-10}$ ) em meio MEM $1 \%$ de SFB, 30 h pós-infecção fixadas com parafolmadeido $4 \%$, permeabilizadas, bloqueadas e incubadas com anticorpo anti-F overnight sob agitação a $4{ }^{\circ} \mathrm{C}$. Após incubação com anticorpo secundário anti-coelho Alexa Fluor 488, as células foram observadas em microscópio de imunofluorescência Zeiss® ${ }^{\circledR}$, Jena, Alemanha e focos de fluorescência do vírus com aumento 4x foram contadas para o cálculo do título, expresso em unidades formadoras de placa (UFP).

\subsection{Plasmídeos}

Os plasmídeos pGEX-PRMT5, pGEX-P, pET-WDR77, pET-N, foram construídos pela Dra. Andressa P. Oliveira e utilizados anteriormente no laboratório (OLIVEIRA, 2013). pCITE-N, pCITE-M2-1, pCITE-P, pCITE-L e pM-Luc foram gentilmente cedidos pelo Dr. Jean-François Eleouét (FIX et al., 2011). Os cDNAs dos genes PRMT5 e WDR77 foram adquiridos da Origene e subclonados no plasmídeo pcDNA-HA pelo Dr. Fernando Simabuco (UNICAMP, Limeira), gerando os plasmídeos pcDNA-HA-PRMT5 e pcDNA-HA-WDR77. 


\subsection{Bactérias}

Foram utilizadas bactérias E. coli: DH5a supE44 $\Delta$ alcU169 (80lacZ\$M15) hsdR17 recA1 endA1 gyra96 thi-1 relA1 (SAMBROOK et al., 1989); e BL21 (DE3) pLysS que permitem a expressão de proteínas, com alta eficiência de qualquer gene sob o controle do promotor T7. A bactéria BL21(DE3) é lisogênica para $\lambda$-DE3, que contém o gene bacteriófago T7 I, e que codifica RNA polimerase T7 sob o controle do promotor lac UV5. Também contém um plasmídeo, pLysS, que transporta o gene que codifica para a lisozima de T7. Genótipo: F- ompT gal dem lon hsdSB (rB- mB-) $\lambda(\mathrm{DE} 3)$ pLysS (cmR).

\subsection{Anticorpos utilizados}

Contra proteínas virais: Anti-N monoclonal (ab94806 - Abcam®, Cambridge, Reino Unido); Anti-N policlonal (produzido no laboratório, Simabuco et al, 2009), Anti-P (ab94965 - Abcam ${ }^{\circledR}$, Cambridge, Reino Unido), Anti-F (ab24011 - Abcam®, Cambridge, Reino Unido), Anti-G (ab94966 - Abcam ${ }^{\circledR}$, Cambridge, Reino Unido).

Contra proteínas celulares: Anti-PRMT5 (ab109451 - Abcam®, Cambridge, Reino

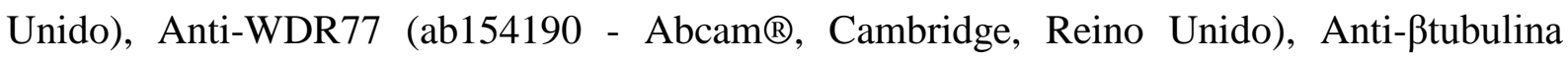
(ab6046 - Abcam®, Cambridge, Reino Unido), Anti-atubulina (ab7291 - Abcam®, Cambridge, Reino Unido), Anti-ßactina (ab8224 - Abcam®, Cambridge, Reino Unido).

Contra metil-arginina e metil-lisina: Anti-arginina metilada (ab414 - Abcam®, Cambridge, Reino Unido), Anti-arginina dimetilada (ab413 - Abcam®, Cambridge, Reino Unido), Anti-lisina metilada (SAB5200093 - Sigma®, Missouri, EUA).

Contra peptídeo FLAG: Anti-Flag (F1804-0 - Sigma®, Missouri, EUA).

Secundários: Anti-camundongo (ab97023 - Abcam ${ }^{\circledR}$, Cambridge, Reino Unido ou A4416 - Sigma ${ }^{\circledR}$, Missouri, EUA), Anti-coelho (ab97051 - Abcam ${ }^{\circledR}$, Cambridge, Reino Unido), Anti-camundongo Alexa Fluor 594 (ab150120 - Abcam® Cambridge, Reino Unido), Anti-coelho Alexa Fluor 488 (ab150081 - Abcam ${ }^{\circledR}$, Cambridge, Reino Unido).

\subsection{Transfecção de DNA}

Buscando as condições com melhor eficiência, foram utilizados diferentes reagentes: Lipofectamine 2000 (Invitrogen®, Califórnia, EUA) e Lipofectamine PLUS (Invitrogen®, Califórnia, EUA). Os protocolos seguidos foram segundo as recomendações dos fabricantes. 


\subsection{Ensaio com minigenoma}

O desenvolvimento do minigenoma como ferramenta de estudo vem do domínio da genética reversa do HRSV, em que a partir de um clone do genoma viral transcrito pela RNA polimerase do fago T7 é produzido um RNA genomico do vírus no citoplasma, que serve de substrato para o conjunto de proteínas virais responsáveis pela transcrição e replicação do genoma, também no citoplasma celular (COLLINS et al., 1995).

A versão utilizada aqui foi desenvolvida mais recentemente, valendo-se da habilidade das células BSRT7/5 em expressar constitutivamente a polimerase T7, e do elemento CITE que posiciona uma estrutura IRES (internal ribosomal entry site) no 5' do mRNA para maior eficiência de tradução, e vem sendo utilizada pelo grupo do Dr. Eleouet (FIX et al., 2011; TRAN et al., 2009). É composta por vetores pCITE com os genes N, M2-1, P ou L do HRSV clonados e que fornecem todas as proteínas responsáveis pela transcrição do genoma viral. $\mathrm{O}$ minigenoma (pM-Luc) também é clonado em pCITE e é composto pelos elementos Leader e Trailer, flanqueando o gene repórter luciferase. Esse gene da luciferase, por sua vez é flanqueado pelas sequencias não traduzidas GS (gene start) e GE (gene end) originalmente a 3' e a 5' do gene SH viral. Para o ensaio de imunofluorescência, células BSRT7/5 foram semeadas em placas de 96 poços e após $24 \mathrm{~h}$ de crescimento, essas células foram transfectadas com uma mistura de: 0,25 $\mu$ g de pCITE-N; 0,0625 $\mu \mathrm{g}$ de pCITE-M2-1; 0,25 $\mu \mathrm{g}$ de pCITE-P; 0,125 $\mu \mathrm{g}$ de pCITE-L; 0,25 $\mu \mathrm{g}$ de pM-Luc. A $24 \mathrm{~h}$ após, as células foram tratadas como descrito no item 3.8 (ver a seguir).

\subsection{Transfecção de siRNA}

Os siRNAs para PRMT5 e controle "scramble" que utilizamos foram adquiridos da QIAGEN®, Hilden, Alemanha. Para a transfecção foi utilizado o reagente Lipofectamine ${ }^{\mathrm{TM}}$ 2000 (Invitrogen®, Califórnia, EUA) ou HiPerfect (QIAGEN®, Hilden, Alemanha). No mesmo dia, pouco antes da transfecção, $10^{4}$ células foram plaqueadas com $100 \mu \mathrm{L}$ de meio livre de antibióticos, em placas de 96 poços, ou $10^{5}$ células foram plaqueadas com $500 \mu \mathrm{L}$ de meio livre de antibióticos, em placas de 24 poços. Para cada amostra foram utilizados a partir da solução estoque $1 \mu$ molar/ $\mu \mathrm{l}$ as quantidades indicadas nos experimentos, diluídos em $50 \mu \mathrm{l}$ de meio MEM (Multiwells de 96 poços), ou adicionados 37,5 ng de siRNA em $100 \mu \mathrm{l}$ de meio MEM (Multiwells de 24 poços). Também foram diluídos $3 \mu 1$ de Hi Perfect ou 0,5 $\mu 1$ de 
Lipofectamina $^{\mathrm{TM}} 2000$ nos mesmos $100 \mu \mathrm{l}$ de meio MEM em que foram diluídos os siRNAs e feita incubação por 10 min a T.A. A mistura siRNA-Lipofectamina foi adicionada ao meio com as células recém repicadas e incubadas a $37{ }^{\circ} \mathrm{C}$ por 24 hs. Também testamos, com protocolo similar, o siRNA para PRMT5 e o controle descritos em Bandyopadhyay et al. 2012, e sua síntese foi encomendada à Life Technologies®, Califórnia, EUA.

\subsection{Imunoprecipitação}

Para realizar a imunoprecipitação após infecção, células Hep-2 ou HEK293T (confluência entre 50-70\%) foram infectadas com HRSV ou transfectadas com pcDNA3-FLAG-N. 24 hs após infecção ou 48 hs após transfecção, as células foram lavadas com PBS e lisadas com tampão de lise celular (Cell Signaling®, Massachusetts, EUA) contendo inibidores de protease (Sigma®, Missouri, EUA) e inibidores de fosfatase (Sigma®, Missouri, EUA).

Para as células infectadas, primeiramente os lisados foram tratados com G-Sepharose (para ser realizado o pré cleaning) sob agitação a $4{ }^{\circ} \mathrm{C}$ por $1 \mathrm{~h}$, seguindo-se centrifugação a $8.000 \mathrm{rpm} \mathrm{a} 4{ }^{\circ} \mathrm{C}$ por $10 \mathrm{~min}$. O pellet foi descartado e em seguida ao sobrenadante foi adicionado o anticorpo anti-N (Abcam ${ }^{\circledR}$, Cambridge, Reino Unido). Após $1 \mathrm{~h}$ com agitação a $4{ }^{\circ} \mathrm{C}$ foi adicionada G-Sepharose, seguindo por mais $1 \mathrm{~h}$ com agitação a $4{ }^{\circ} \mathrm{C}$. Os complexos G-Sepharose-Ac-proteínas obtidos por centrifugação foram lavados com PBS.

Para as células transfectadas com FLAG-N, os lisados foram centrifugados por 10 mins a $5.000 \mathrm{rpm}$. O pellet foi descartado e ao sobrenadante foram adicionadas anti-Flag beads (Sigma®, Missouri, EUA), que consistem de anticorpos anti-FLAG ligados a micro esferas, por 2 hs TA ou overnight a $4{ }^{\circ} \mathrm{C}$. As micros-esferas foram centrifugadas a $1.000 \mathrm{rpm}$ por 1 min e o sobrenadante foi descartado.

\subsection{Western blotting}

Após a corrida de um gel de SDS-PAGE, o protocolo convencional de Western Blot foi seguido utilizando: membranas de nitrocelulose Hybond-ECL (Amersham Biosciences®, Amersham, Reino Unido) e o SuperSignal West Pico Chemiluminescent Substrate (Pierce ${ }^{\circ}$, Massachusetts, EUA). 


\subsection{Microscopias de imunofluorescência e confocal}

Para imunoflorescência, as células foram cultivadas em placas de 96 poços, e 24 hs após transfecção com o minigenoma (ou para as condições indicadas nas legendas das figuras descrevendo outros experimentos) o meio de cultivo das células foi retirado, feita lavagem com PBS pH 7,5, e as células foram fixadas utilizando metanol ou paraformaldeído $4 \%$ a $4{ }^{\circ} \mathrm{C}$ por 5 mins. Após a fixação as células foram lavadas 2 x com PBS e incubadas com PBS contendo $0,1 \%$ de Triton X-100 e 0,5\% de BSA (albumina bovina), por 15 mins a T.A. As células foram lavadas novamente 2 x com PBS e incubadas com anticorpo primário diluído em PBS contendo Tween $0,2 \%$ e $0,5 \%$ de BSA. Os anticorpos primários utilizados foram anti-PRMT5 e anti-N (ver item 3.2). Após a incubação por 1 h a T.A., as células foram lavadas com PBS contendo Tween 0,2\%3 x por 5 mins cada, e incubadas com anticorpo secundário (anti-cabra e camundongo, respectivamente, ver item 3.2) conjugado a um fluoróforo, diluído em PBS contendo Tween 0,2 \% e 0,5 \% de BSA. E o núcleo corado com DAPI (Invitrogen®, Califórnia, EUA) na diluição de 1:1000, incubado juntamente com o secundário. Após essa incubação as células foram lavadas com PBS contendo Tween 0,2 \% por 3 x, 5 mins cada, as lâminas e analisadas em microscópio de imunofluorescência Zeiss®, Jena, Alemanha.

Para a imunoflorescência a ser analisada em microscópio confocal, células Hep-2 foram plaqueadas em Chamber Slides (NUNC, Califórnia, EUA), tranfectadas com pcDNAHA-PRMT5 e/ou pcDNA-HA-WDR77, 24 hs depois infectadas e fixadas depois de $30 \mathrm{hs}$. Após permeabilização da membrana e incubação com os anticorpos primários, anti-PRMT5, anti-WDR77 ou anti-N (Abcam®, Cambridge, Reino Unido), e secundários (ver item 3.2), como descrito acima, foi feita a montagem das lâminas em glicerol tamponado. A observação foi feita no microscópio confocal multifotón (Zeiss®, Jena, Alemanha) disponível no CEFAPICB-USP, com o auxílio da equipe responsável.

\subsection{Espectrometria de massas}

Para a análise feita no CEFAP-ICB-USP, após a coloração do gel de poliacrilamida com Coomassie Blue, a banda de interesse foi cortada, coletada em tubos e lavadas com 2 vezes com acetonitrila (ACN) $50 \%$. Os pedaços de gel foram lavados novamente e secados em SpeedVac. Foi adicionado 250 ng de tripsina modificada (Promega ${ }^{\circledR}$, Wisconsin, EUA) diluída em bicarbonato de amônio $50 \mathrm{mM}$ e incubado a $37{ }^{\circ} \mathrm{C}$ por cerca de 16 hs. As proteínas 
foram extraídas do gel primeiro utilizando-se bicarbonato de amônio $20 \mathrm{mM}$, e em seguida ACN $40 \%$ e ácido fórmico $2 \%$. As amostras foram concentradas e enviadas ao CEFAP onde a análise foi feita no equipamento LTQ-Orbitrap Velos ETD (Thermo®, Califórnia, EUA) acoplado ao Easy nanoLC II (Thermo®, Califórnia, EUA). Os dados foram analisados, usando-se o banco de dados do SwissProt.

As análises feitas pela empresa MSBioworks, Michigan, EUA, foram utilizando um protocolo especial para analisar modificações pós tradução, o PTM-Profiling plus (MSB-10). A análise foi feita em equipamento nano LC-MS/MS acoplado a um Waters NanoAcquity HPLC. A digestão foi feita com tripsina, quimotripsina ou elastase, dando uma cobertura de $98 \%$, e os dados analisados pela própria MSBioworks, Michigan, EUA, utilizando o banco de dados Swiss Prot. Para obter a prestação desse serviço, enviamos as bandas excisadas de gel SDS-PAGE corado com Coomassie Blue, como comentado adiante nos resultados enfocando essa análise.

\subsection{Análise da interação in bactéria}

Bactérias E. coli BL21 eletrocompetentes foram eletroporadas com os plasmídeos pET-N, pGEX-P, pGEX-PRMT5 ou pET-WDR77 + pGEX-PRMT5 obtidos anteriormente no laboratório (Oliveira 2013). Ficaram em agitação por $1 \mathrm{~h} \mathrm{em} 1 \mathrm{~mL}$ de LB sem antibióticos. Em seguida foram plaqueadas em placas com LB ágar com os antibióticos adequados e deixadas na estufa a $37^{\circ} \mathrm{C}$ overnight. As bactérias foram crescidas em LB com canamicina $10 \mathrm{mg} / \mathrm{ml}$ (para plasmídeos pET), ampicilina $50 \mathrm{mg} / \mathrm{ml}$ (pGEX) ou ampicilina + canamicina (para ambos), induzidas com IPTG, coletadas por centrifugação. A seguir foram sonicadas em sonicador S-250D (Branson®, Missouri, EUA) por $3 \mathrm{~min}$, divididos em pulsos de $30 \mathrm{~s}$ separados por 1 min de pausa, no gelo. Depois de centrifugação a $5.000 \mathrm{rpm}$ por $45 \mathrm{~min}$, GSbeads (beads de Glutationa-Sepharose, GE) foram adicionadas ao sobrenadante, seguindo incubação overnight a $4{ }^{\circ} \mathrm{C}$ sob agitação. O pellet de GS-beads+proteínas obtido por centrifugação foi analisado por SDS-PAGE e Western Blot.

\subsection{Inibidores de metilação e demetilação}

Para o ensaio de inibição da metilação e demetilação de arginina: o inibidor de PRMT5, EPZ051666, foi adquirido da Cayman Chemical Company, Michigan, EUA; e o inibidor de demetilação, NOG (O-9390), foi adquirido da Sigma® (Missouri, EUA). O ensaio 
de toxicidade consistiu em cultivar células Hep-2 ou Hek293T em placas de 24 poços (confluência de 60 \%-70 \%). O meio de cultivo normal foi substituído por MEM 2 \% SFB e antibióticos com diferentes concentrações do EPZ015666 $(10 \mu \mathrm{M}, 5 \mu \mathrm{M}, 1 \mu \mathrm{M}$ ou apenas DMSO), e as células incubadas a $37^{\circ} \mathrm{C}$ por 96 hs. Já para o NOG as concentrações utilizadas foram $20 \mathrm{mM}, 10 \mathrm{mM}, 5 \mathrm{mM}$ ou apenas DMSO, e as células incubadas a $37^{\circ} \mathrm{C}$ por $48 \mathrm{hs}$. Depois da incubação as células foram lavadas com PBS, fixadas com metanol gelado, coradas com cristal violeta por 10 min e o excesso do corante foi retirado com água corrente. Para o teste de toxicidade com os dois inibidores, células Hep-2 foram plaqueadas em multiwell de 24 poços e incubadas com meio MEM $2 \%$ SFB com antibióticos e $3 \mu \mathrm{M}$ de EPZ015666 + $2 \mathrm{mM}$ de NOG e incubadas a $37{ }^{\circ} \mathrm{C}$ por 48 hs. Células HEK293T foram incubadas com $10 \mu \mathrm{M}$ de EPZ015666 + $2 \mathrm{mM}$ de NOG e incubadas a $37^{\circ} \mathrm{C}$ por $48 \mathrm{hs}$. Em seguida foram coradas com cristal violeta como já descrito.

Para medir o efeito do inibidor na replicação viral, células Hep-2 foram incubadas com $4 \mathrm{mM}$ ou $2 \mathrm{mM}$ de NOG; $3 \mu \mathrm{M}$ ou 1,5 $\mu \mathrm{M}$ de EPZ015666 ou $3 \mu \mathrm{M}$ de EPZ015666 + $2 \mathrm{mM}$ de NOG; células HEK293T incubadas com $4 \mathrm{mM}$ ou $2 \mathrm{mM}$ de NOG; $5 \mu \mathrm{M}$ ou $10 \mu \mathrm{M}$ de EPZ015666 ou $10 \mu \mathrm{M}$ de EPZ015666 + $2 \mathrm{mM}$ de NOG. Depois de 24 hs foram infectadas com HRSV (3 MOI) em meio MEM com $2 \%$ de SFB e antibióticos por 3 hs, seguindo-se troca para meio MEM $2 \%$ SFB e antibióticos, com os respectivos inibidores de cada condição experimental, e incubação a $37^{\circ} \mathrm{C}$ por 48 hs. A coleta das células foi feita com tampão de amostra SDS 1x e o extrato analisado por Western Blotting.

Para o ensaio dos inibidores de metilação em lisina, foram utilizados os mesmos protocolos do inibidor de metilação em arginina. Para o teste de toxicidade foram utilizadas as concentrações de $10 \mu \mathrm{M}, 20 \mu \mathrm{M}$ e $40 \mu \mathrm{M}$ para UNC0631;0,5 $\mu \mathrm{M}, 1 \mu \mathrm{M}$ e $2 \mu \mathrm{M}$ para UNC0638; $5 \mu \mathrm{M}, 10 \mu \mathrm{M}$ e $20 \mu \mathrm{M}$ para UNC0646; e 1,5 $\mu \mathrm{M}, 3 \mu \mathrm{M}$ e $6 \mu \mathrm{M}$ para EPZ004777 (todos adquiridos da Cayman Chemical Company, Michigan, EUA). Para o teste na replicação viral, as concentrações utilizadas foram de $20 \mu \mathrm{M}, 4 \mu \mathrm{M}, 20 \mu \mathrm{M}$ e $12 \mu \mathrm{M}$ respectivamente por 72 hs, sendo a infecção 24 hs após o inicio da incubação com inibidores. 


\section{RESULTADOS}

4.1 Confirmação da interação entre o metilossomo e a proteína $N$ expressa por infecção.

Fizemos este experimento no sentido de confirmar os dados obtidos em células HEK293T por Oliveira et al (2013), agora utilizando um anticorpo monoclonal anti $\mathrm{N}$ disponível comercialmente.

Utilizamos Hep2, uma linhagem em que o vírus é comumente cultivado e que tem uma origem tecidual diferente, buscando assim confirmar a universalidade do fenômeno. As imunoprecipitações foram feitas com anticorpos contra as proteínas celulares WDR77, segundo Antonysamy et al. (2012) e Oliveira et al. (2013), o componente do metilossomo que interage com o alvo e recruta a metil-tranferase, e Hsp70 (controle positivo), e com um anticorpo contra a própria N (monoclonal Abcam ${ }^{\circledR}$, Cambridge, Reino Unido). Para a detecção da proteína viral $\mathrm{N}$ foi realizado Western Blotting com anticorpo anti-N, policlonal obtido em camundongos no laboratório (SIMABUCO et al., 2009). O resultado apresentado na figura abaixo indica que a proteína $\mathrm{N}$ foi co-imunoprecipitada com a WDR77, mostrando que essa proteína (e consequentemente o metilossomo) estaria sendo recrutada pelo vírus para viabilizar a funcionalidade do nucleocapísideo.

Figura 6 - Co-imunoprecipitação de N com WDR77 em células Hep-2 infectadas

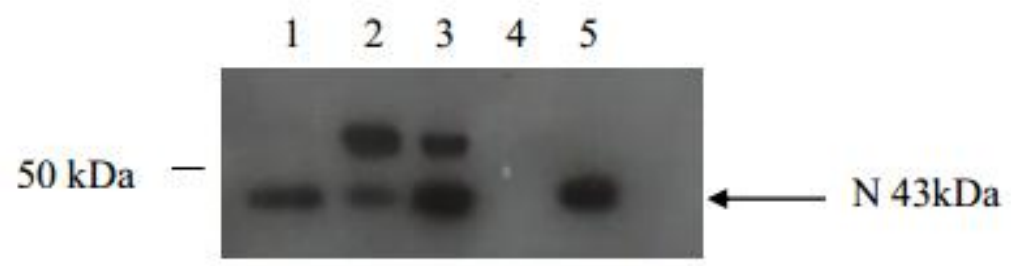

Células Hep-2 foram infectadas com HRSV e coletadas após 24 hs. As amostras foram processadas para imunoprecipitação e feito Western Blotting (ver itens 3.1, 3.8 e 3.9) com os seguinte anticorpos (ver item 3.4): 1 - anti-WDR77; 2 - anti-Hsp70; 3 - anti-N monoclonal; 4 extrato de Hep-2 não infectada; 5 - vírus purificado. O anticorpo primário para detecção foi o anti$\mathrm{N}$ policlonal. 


\subsection{Análise da interação N-WDR77/PRMT5 com proteínas expressas em bactérias}

No sentido de obter evidência de que ocorre interação entre $\mathrm{N}$ e o metilossomo in vitro, utilizamos vetores de expressão bacteriana obtidos anteriormente no laboratório (OLIVEIRA, 2013). Os genes PRMT5 (GI:19684070) e WDR77 (NM 024102) tiveram sequencias sintetizadas com otimização para expressão em bactérias e foram clonados nos vetores pET e pGEX (OLIVEIRA, 2013). pET-N foi gentilmente cedido pelo Dr. JeanFrançois Eléouet (CASTAGNE et al. 2004).

\subsubsection{Análise da interação N-WDR77 in bacteria}

A metodologia de interação in bacteria permite analisar se ocorre a interação das proteínas quando bactérias BL21 (pLys) são co-transformadas com os plasmídeos baseados nos vetores pGEX e pET que possuem marcas de resistência distintas (CASTAGNE et al. 2004). Aqui utilizamos pGEX-WDR77 e pET-N, seleção com ampicilina + canamicina, e em seguida feito o pull down com GS-beads (ver item 3.12). O resultado apresentado abaixo mostra que não foi possível observar a interação entre a proteína GST-WDR77 e a proteína His-N, pois a maior parte delas se encontram na fração insolúvel, tanto em análise do gel corado com Coomassie Blue quanto na analise por Western Blotting (Figura 7).

Figura 7 - Análise da interação entre WDR77 e N
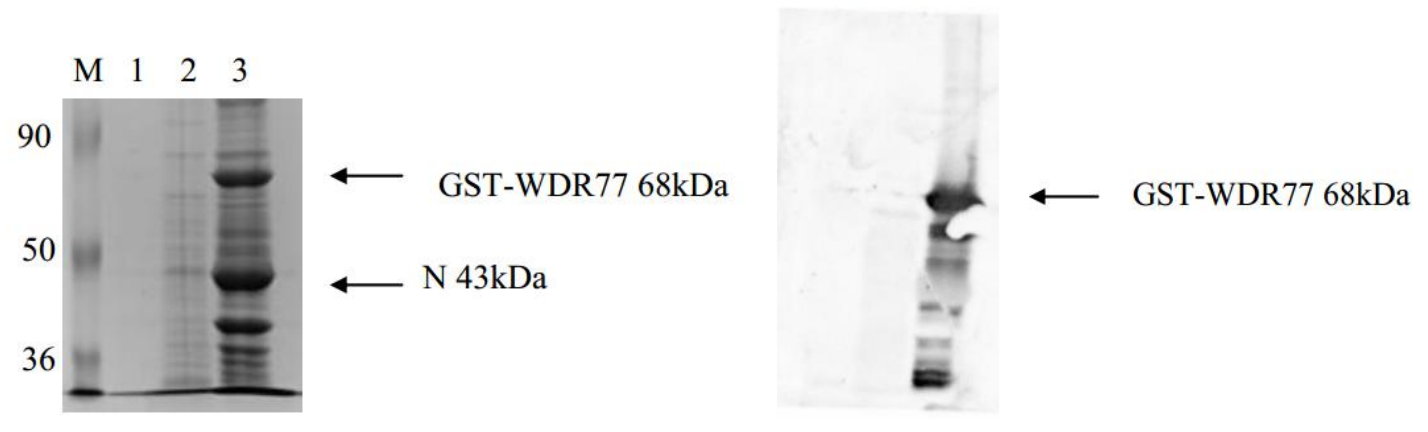

Bactérias BL21 foram eletroporadas com pGEXWDR77 e pET-N, selecionadas, lisadas $e$ pull down feito com GS-beads (ver item 3.12). Está apresentado gel de SDS-PAGE 10\% corado com Coomassie Blue à esquerda e Western blotting detectado com anticorpo anti-WDR77 à direita. Nas colunas, M - marcador; 1 - proteínas ligadas às GS-beads; 2 - proteínas no sobrenadante das GSbeads; 3 - pellet do lisado de bactérias. 


\subsubsection{Análise da formação do metilossomo in bacteria}

Como visto no item anterior, tentar expressar somente a proteína WDR77 in bacteria fez com que a proteína ficasse insolúvel. A WDR77 interage com a proteína PRMT5 dentro da célula para formar o metilossomo para então metilar seus alvos. Por isso foram feitas tentativas de co-transformação da bactéria com pGEX-PRMT5 + pET-WDR77 ou pETPRMT5 + pGEX-WDR77 para verificar se há montagem do metilossomo na bactéria e estabilização na forma solúvel. O par pET-PRMT5 + pGEX-WDR77 não ficou solúvel (dado não apresentado). Já o par pGEX-PRMT5 + pET-WDR77 apresentou bandas (Figura 8) em Western Blotting tanto para a PRMT5 quanto para a WDR77, indicando que as duas proteínas estavam solúveis e foram capturadas pelas GS-beads, apesar de parte ainda estar insolúvel.

Figura 8 - Co-transformação com pGEX-PRMT5 + pET-WDR77

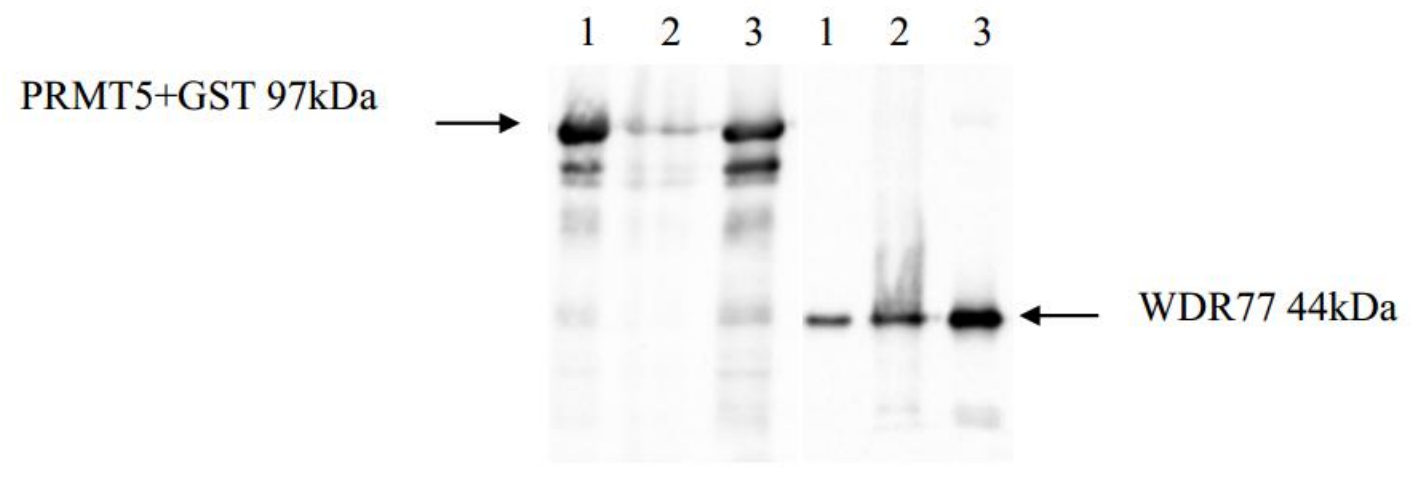

As bactérias foram lisadas e o pull down feito com GS-beads (ver item 3.12). 1 - proteínas ligadas às GS-beads; 2 - proteínas no sobrenadante das GS-beads; 3 - pellet do lisado de bactérias. Western Blotting com detecção por anti-PRMT5 (esquerda) e anti-WDR77 (direita).

Depois de verificar que pela co-transformação da bactéria com pGEX-PRMT5 + pETWDR77 as proteínas ficam solúveis, foi feito um gel não desnaturante para verificar se as proteínas estavam separadas ou se formavam um complexo compatível com o tamanho do metilossomo. O gel não desnaturante corado com Coomassie Blue (Figura 9) indica uma banda de peso molecular compatível com o complexo. No Western Blotting, foi possível observar a detecção das duas proteínas nessa amostra (Figura 10). 
Figura 9 - Gel não desnaturante para análise da formação do metilossomo in bacteria.

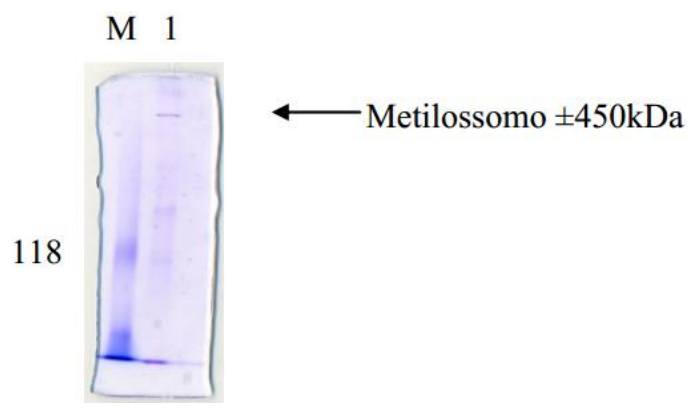

Gel SDS-PAGE não desnaturante 8\% (não contém SDS em sua composição), corado com Coomassie Blue. Bactérias foram co-transformadas com pGEX-PRMT5 e pET-WDR77, lisadas e pull down feito com GS-beads (ver item 3.12). Nas colunas: M - marcador; 1 - Proteínas ligadas às GS-beads.

Figura 10 - Western Blottings do metilossomo formado in bacteria.

1

118

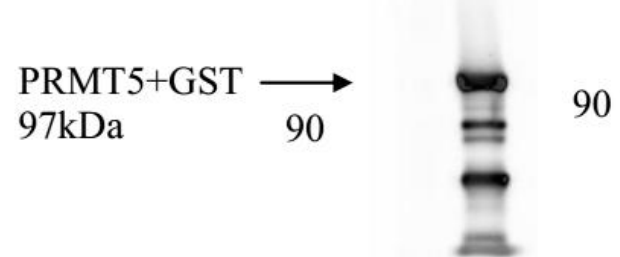

2

118

0

A mesma amostra da figura 10 foi corrida em SDS-PAGE normal, não desnaturante. Estão apresentados Western Blottings. Anticorpos primários: 1 - anti-PRMT5; 2 - anti-WDR77 (ver item 3.4).

\subsubsection{Análise da interação N-Metilossomo in bactéria}

Após verificar que é possível expressar o metilossomo tentamos obter evidências da sua interação com $\mathrm{N}$ in vitro. As bactérias foram transformadas com pGEX-PRMT5 + pETWDR77 ou pET-N, e as proteínas produzidas foram purificadas com GS-beads (GE®, Nova Iorque, EUA) ou com o NiNTA-Spin Kit (QIAGEN®, Hilden, Alemanha), respectivamente. Em seguida foi feita a mistura de GS-beads (sem eluir, metilossomo a elas ligado) e $\mathrm{N}$ purificada (eluida, em solução). Com essa estratégia porém, não foi possível observar a interação por detecção das proteínas em Western Blotting (resultados não apresentados). Por fim tentou-se fazer a obtenção do metilossomo em uma bactéria, e da $\mathrm{N}$ em 
outra. Essas bactérias com o metilossomo e as que expressaram a proteína $\mathrm{N}$ foram misturadas e sonicadas juntas. Bactérias que expressaram a $\mathrm{N}$ foram também sonicadas sozinhas para o controle negativo. O pull down foi feito com GS-beads em ambas, e um Western Blotting foi feito para analisar as proteínas que ficaram associadas com as beads. O resultado abaixo mostra que a proteína $\mathrm{N}$ ficou associada com as proteínas do metilossomo, indicando interação (Figura 11). Também foi possível observar as mesmas proteínas em gel corado com Coomassie Blue (Figura 12).

Figura 11 - Western Blottings da interação das proteínas do metilossomo com N.

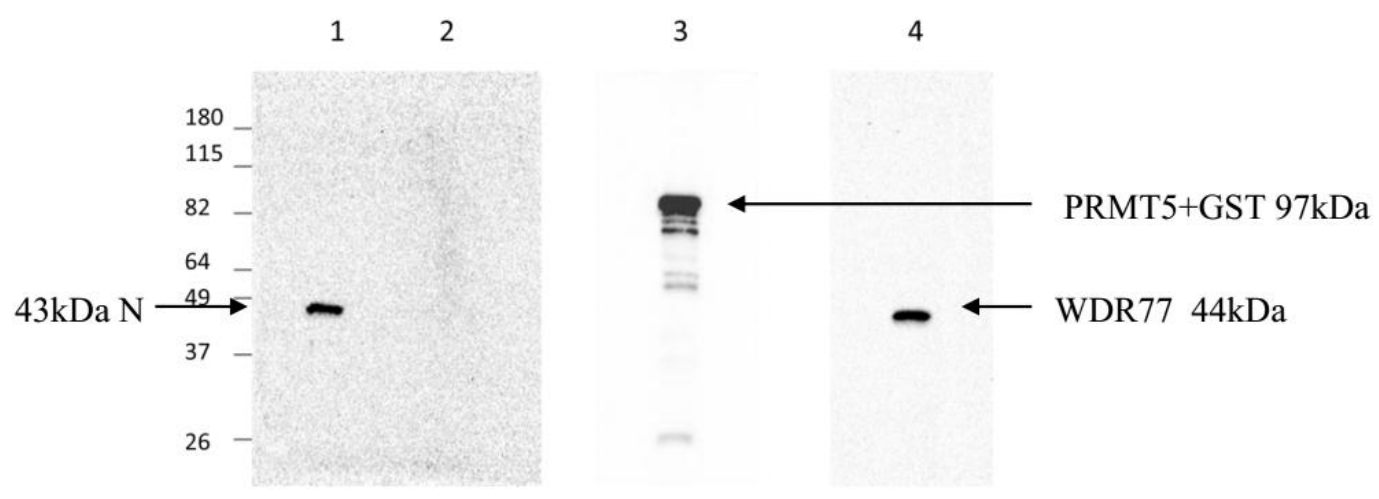

Bactérias co-transformadas com plasmídeos que expressam as proteínas do metilossomo ou que expressam a proteína $\mathrm{N}$, foram sonicadas juntas (1, 3 e 4) ou só $\mathrm{N}$ em separado (2), e o pull down feito com GS-beads nos dois extratos. Estão apresentados Western Blottings com os anticorpos primários: 1 e 2- anti-N; 3 - anti-PRMT5; 4 - anti-WDR77.

Figura 12 - Gel corado com Coomassie Blue da interação entre N e o metilossomo.

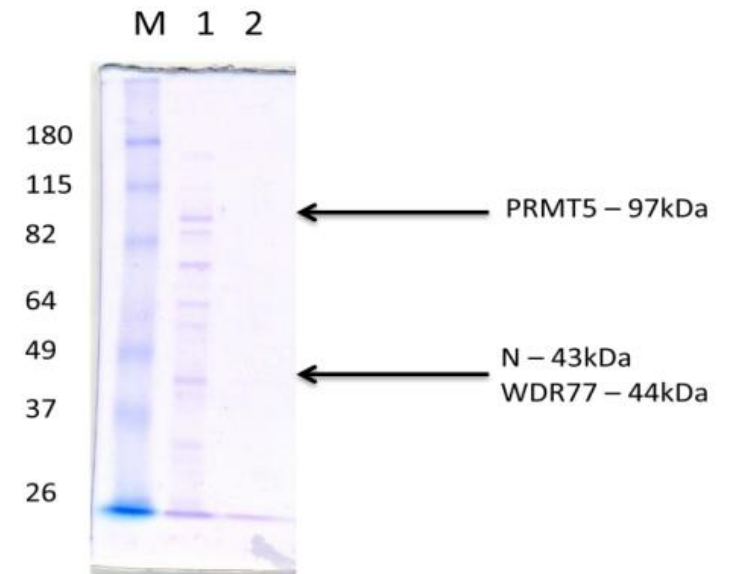

Gel de SDS-PAGE $12 \%$ feito a partir das mesmas amostras que a figura anterior. $\mathrm{M}$ - marcador; 1 - bactérias sonicadas juntas (GST-PRMT5/His-WDR77 + His-N); 2 - Só bactérias expressando His-N sonicadas. 
Para verificar e reforçar o resultado obtido o experimento foi repetido, desta vez com controle negativo e positivo. Para tal, bactérias foram transformadas com pGEX-PRMT5 + pETWDR77, pGEX-P ou pET-N. O mesmo protocolo do experimento anterior foi utilizado. Bactérias expressando o metilossomo foram sonicadas com bactérias expressando a $\mathrm{N}$, bactérias expressando a proteína $\mathrm{P}$ sonicadas juntamente com as que expressam a $\mathrm{N}$ (controle positivo, visto em trabalho anterior, Castagné et al (2004), e a N sozinha (controle negativo). Pull down foi feito com GS-beads em todos os casos e Western Blotting para analisar as proteínas (Figura 13). O resultado mostrou que juntamente com a PRMT5 veio a $\mathrm{N}$, o controle positivo apareceu como esperado e não foi possível observar nenhuma banda no controle negativo, indicando que existe a interação entre o metilossomo e a proteína $\mathrm{N}$.

Figura 13 - Western Blottings da interação das proteínas do metilossomo com a N.

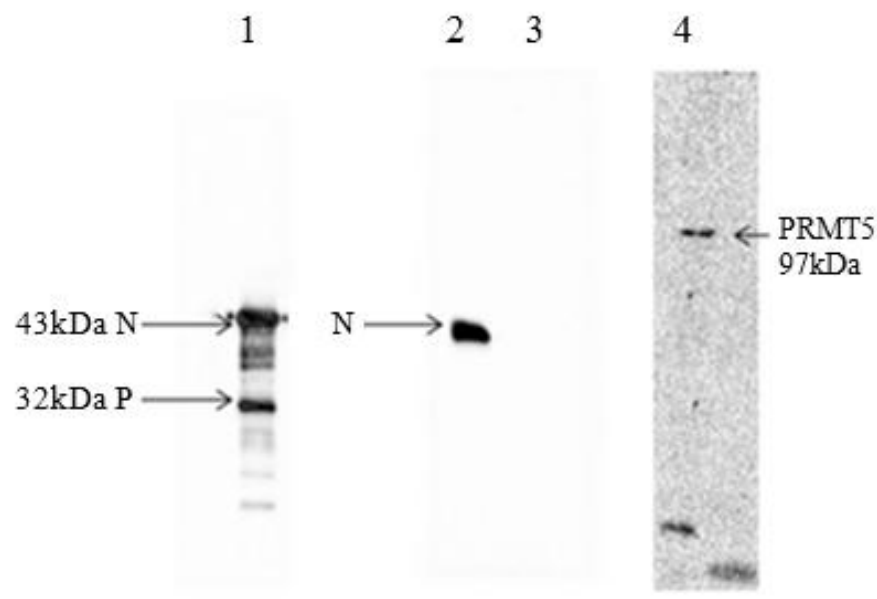

Bactérias co-transformadas com plasmídeos: pET-N; pGEX-P; pGEX-PRMT5+pET-WDR77. Foram lisadas e sonicadas juntas como indicado a seguir e pull down feito com GS-beads. 1 - pull down de GST-P + His-N revelado com anti-N e anti-P (controle positivo de interação); 2 - pull down de GST-PRMT5/His-WDR77 + His-N revelado com anti-N (detectando a interação Nmetilossomo); 3 - pull down de GST + His-N revelado com anti-N (controle negativo); 4 - pull down de GST-PRMT5/His-WDR77 + His-N revelado com anti-PRMT5.

\subsection{Co-localização intracelular entre Ne PRMT5 em células transfectadas com minigenoma}

A imunofluorescência permite que seja observada a co-localização intracelular das proteínas de interesse. Nas células BSRT7, tranfectadas com o sistema do mini-genoma, que é composto pelos plasmídeos pCITE-N, pCITE-M2, pCITE-P, pCITE-L, e pM-Luc ocorre a expressão das proteínas que mimetizam o sistema de replicação viral (ver item 3.6). Assim, 
nosso objetivo com esse experimento foi inferir interação através da co-localização das proteínas N e PRMT5. Para tal foi feita a imunofluorescência onde as células, depois de fixadas, foram incubadas com anticorpos anti-PRMT5 e anti-N, e com anticorpos secundários de diferentes origens (coelho e camundongo, ver item 3.10). O resultado apresentado abaixo (figura 14) mostra que ocorre a co-localização das proteína celular PRMT5 com a viral N nos corpúsculos de inclusão, indicando que esta proteína seria recrutada pelo vírus durante sua replicação.

Figura 14 - Imunofluorescênia das células BRST7 transfectadas com minigenoma.
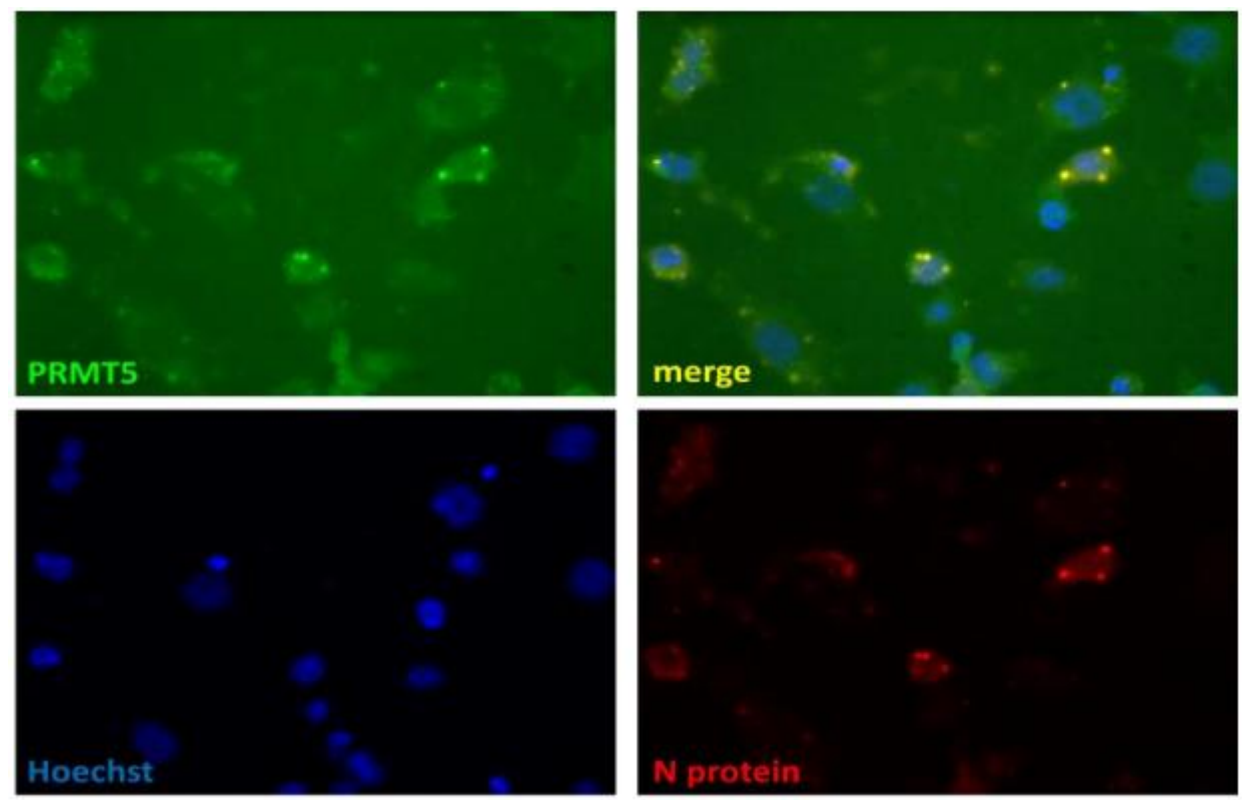

Plasmídeos que expressam as proteínas virais N, P, M2 e L, e um minigenoma de HRSV, foram transfectados (ver item 3.4) e 24 hs depois as células foram fixadas e incubadas com os anticorpos anti-PRMT5 e anti-N e os secundários anti-rabbit e anti-mouse (Alexafluor-488 e 594, respectivamente, da Life Techonologies®, Califórnia, EUA), e os núcleos corados com Hoechst.

4.4 Co-localização entre metilossomo e $N$ detectada por imunofluorescência em células infectadas

Após a confirmação da co-localização de PRMT5 e $\mathrm{N}$ através do sistema de minigenoma, o próximo passo foi tentar observar a interação $\mathrm{N}$-metilossomo por imunofluorescência em células infectadas. Para isso, células Hep-2 foram infectadas e 24 hs pós-infecção foram fixadas, sua membrana permeabilizada e incubadas com os anticorpos 
primários, anti-PRMT5, anti-WDR77 ou anti-N (ver item 3.10). Porém, não foi possível observar a co-localização das proteínas (não apresentado).

Como a expressão de PRMT5 estava muito fraca para a imunofluorescência, resolvemos tentar a estratégia de aumentar a expressão das proteínas celulares e verificar se, desta maneira, é possível observar a co-localização. Para isso, os plasmídeos pcDNA-HAPRMT5 e/ou pcDNA-HA-WDR77 (ver item 3.2) foram transfectados em células HEK293T (apresentam melhor resultado de transfecção do que a Hep-2), que 24 hs depois foram infectadas. O resultado das figuras 15 a 17 mostram que foi possível observar a co-localização da N tanto com a PRMT5 e a WDR77 transfectadas sozinhas, quanto na dupla transfecção.

Figura 15 - Co-localização N-PRMT5 com transfecção.

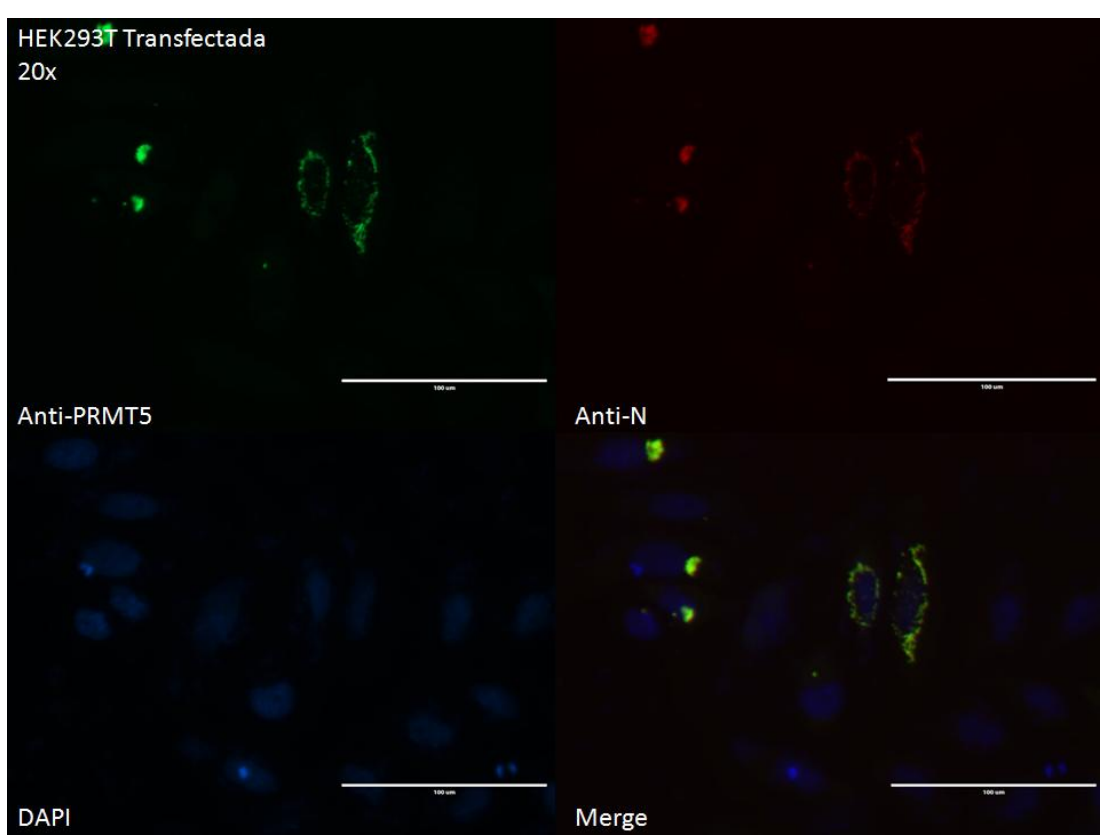

Células HEK293T transfectadas com plasmídeo pcDNA-HA-PMRT5, 24 hs depois foram infectadas e 24 hs pós infecção fixadas com paraformaldeído 4\% e incubadas com anti-PRMT5 e anti-N (Abcam®, Cambridge, Reino Unido) e depois com os secundários anti-coelho e anticamundongo (acoplados a Alexafluor-488 e 594, respectivamente, da Life Techonologies®, Califórnia, EUA) e os núcleos corados com DAPI. Estão apresentados os resultados da imunofluorescência detectada com microscópio Zeiss $®$, Jena, Alemanha e filtros apropriados. 
Figura 16 - Co-localização N-WDR77 com transfecção.

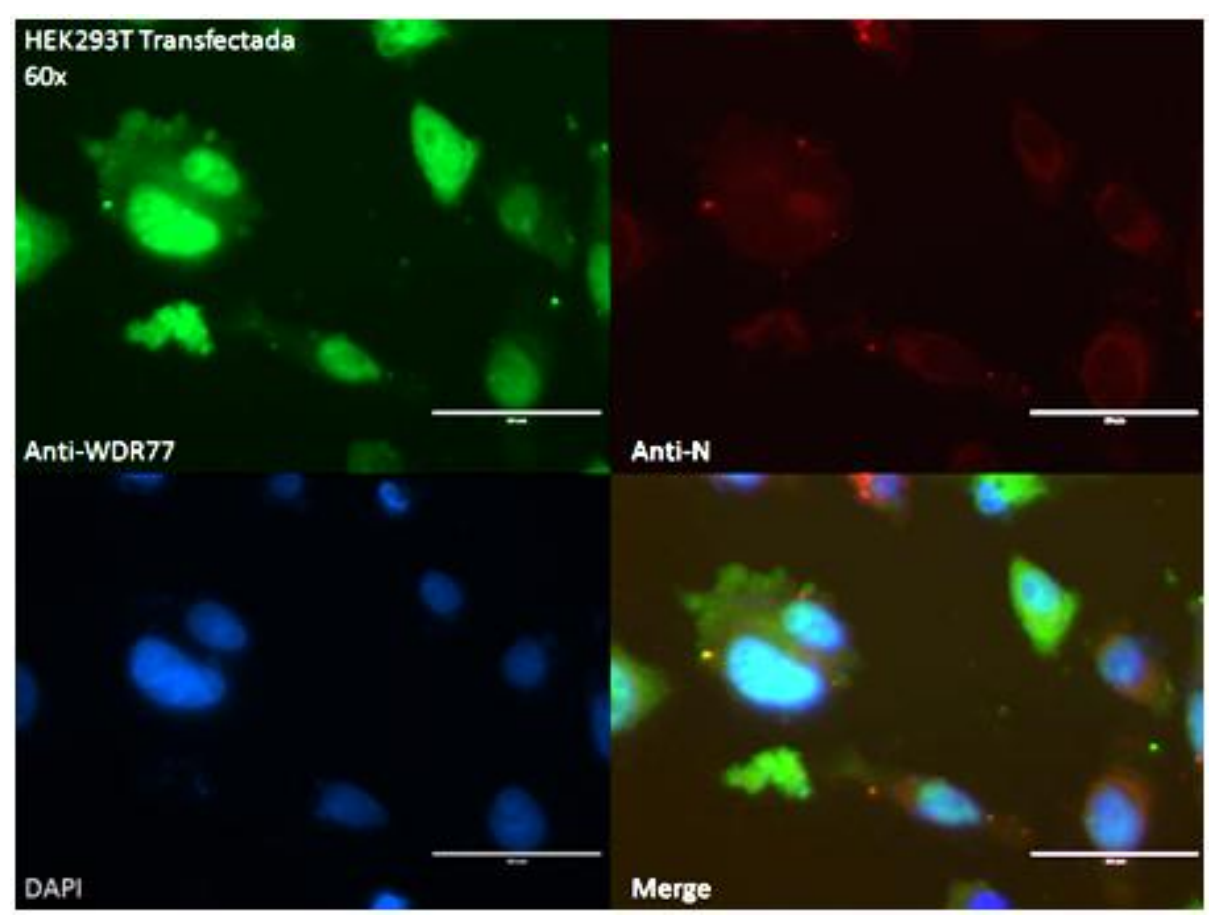

Células HEK293T transfectadas com plasmídeo pcDNA-HA-WDR77, 24 hs depois foram infectadas e 24 hs pósinfecção fixadas com paraformaldeído 4\% e incubadas com anti-WDR77 e anti-N (Abcam ${ }^{\circledR}$, Cambridge, Reino Unido) e depois com os secundários anti-coelho e anticamundongo (acoplados a Alexafluor-488 e 594, respectivamente, da Life Techonologies®, Califórnia, EUA) e os núcleos corados com DAPI. Estão apresentados os resultados da imunofluorescência detectada com microscópio Zeiss ${ }^{\circledR}$, Jena, Alemanha e filtros apropriados. 
Figura 17 - Co-localização N-PRMT5/WDR77.

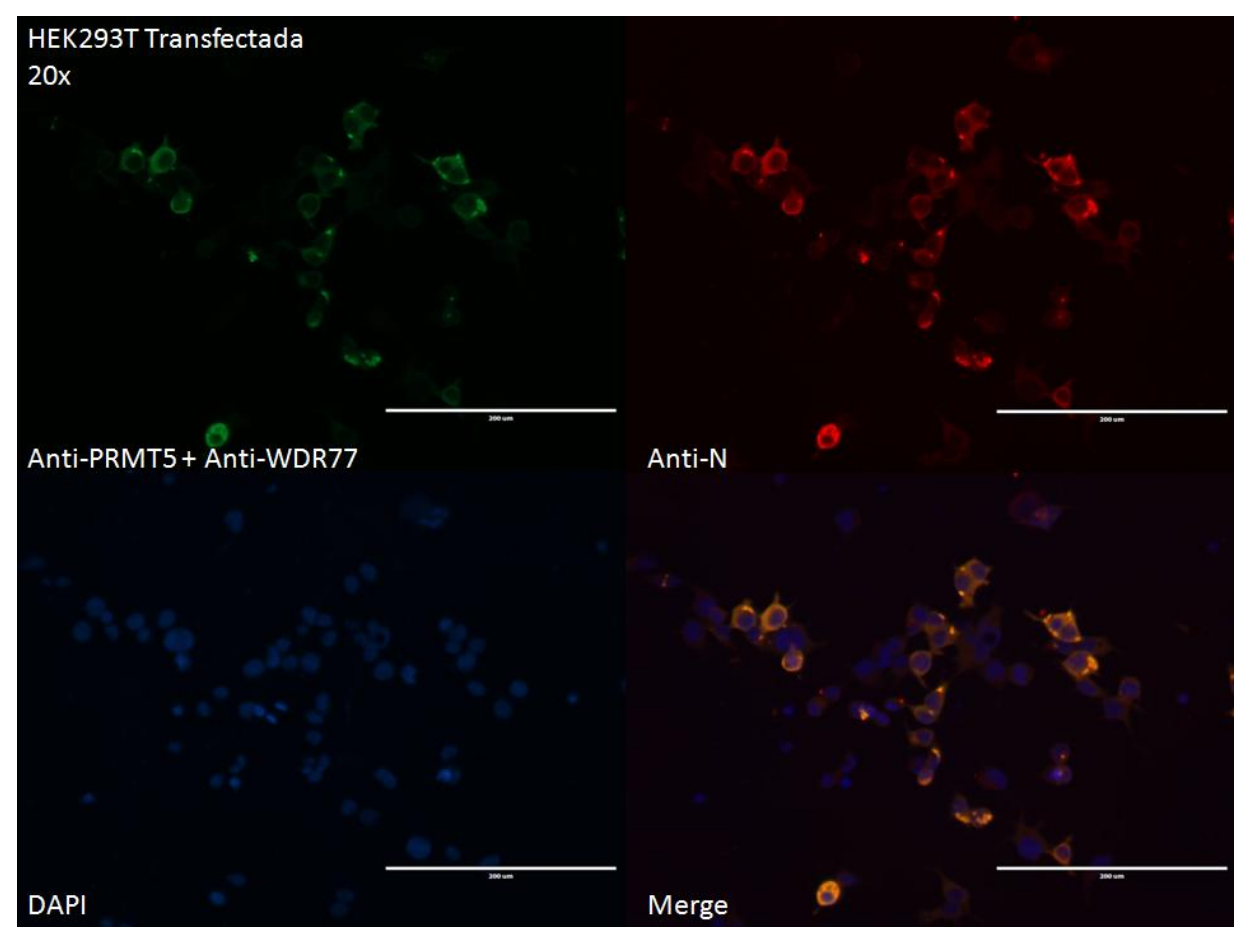

Células HEK293T transfectadas com plasmídeo pcDNA-HA-PMRT5 e pcDNA-HA-WDR77, 24 hs depois foram infectadas e 24 hs pós-infecção foram fixadas com paraformaldeído $4 \%$ e incubadas com anti-PRMT5, anti-WDR77 e anti-N (Abcam ${ }^{\circledR}$, Cambridge, Reino Unido) e depois com os secundários anti-coelho e anti-camundongo (acoplados a Alexafluor-488 e 594, respectivamente, da Life Techonologies ${ }^{\circledR}$, Califórnia, EUA) e os núcleos corados com DAPI. Estão apresentados os resultados da imunofluorescência detectada com microscópio Zeiss®, Jena, Alemanha. e filtros apropriados.

Para confirmar os resultados obtidos por imunofluorescência, também foram feitos experimentos para observar a co-localização por imunofluorescência confocal. Células Hep-2 foram tranfectadas com pcDNA-HA-PRMT5 e/ou pcDNA-HA-WDR77, seguindo o procedimento descrito no item 3.10, e os resultados estão apresentados nas figuras 18 a 20.

Consideramos que nestes experimentos temos também indicação de co-localização entre a proteína N e PRMT5, WDR77 e/ou PRMT5+WDR77. Na transfecção com as proteínas separadas (figuras 18 e 19), observa-se co-localização em pequenos pontos ao redor dos corpúsculos de inclusão. Já na transfecção dupla, a co-localização se apresenta mais forte e também ao redor do corpúsculo. 
Figura 18 - Co-localização da PRMT5 e N por imunofluorescência confocal.

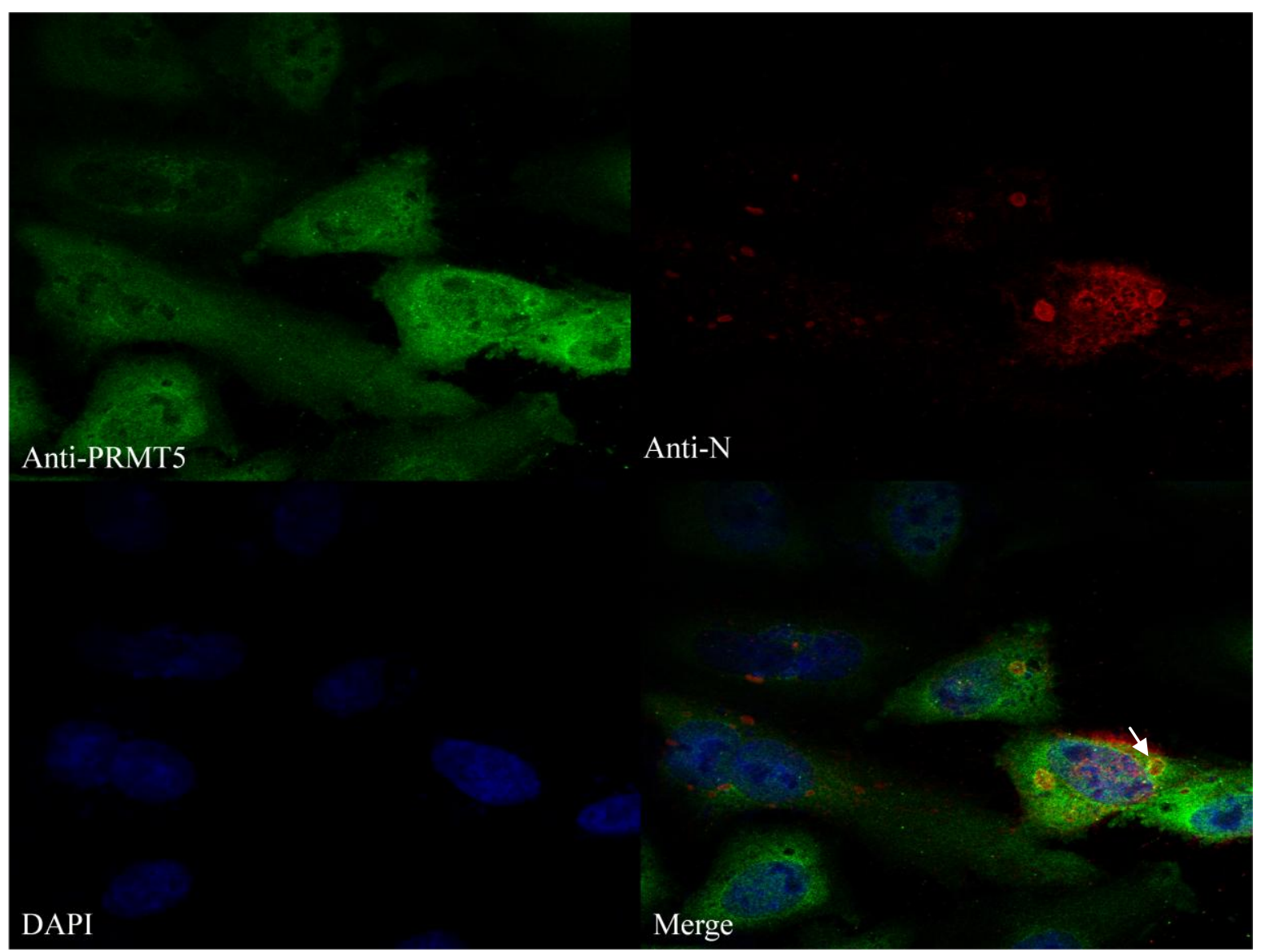

Células Hep-2 transfectadas com plasmídeo pcDNA-HA-PMRT5, 24 hs depois foram infectadas e 24 hs pós-infecção foram fixadas com paraformaldeído 4\% e incubadas com anti-PRMT5 e anti-N (Abcam ${ }^{\circledR}$, Cambridge, Reino Unido) e depois com os secundários anti-coelho e anti-camundongo (acoplados a Alexafluor-488 e 594, respectivamente, da Life Techonologies®, Califórnia, EUA) e os núcleos corados com DAPI. Estão apresentados os resultados da imunofluorescência confocal detectada com microscópio Zeiss® LSM 780-NLO, Jena, Alemanha, e filtros apropriados. 
Figura 19 - Co-localização da WDR77 e N por imunofluorescência confocal.

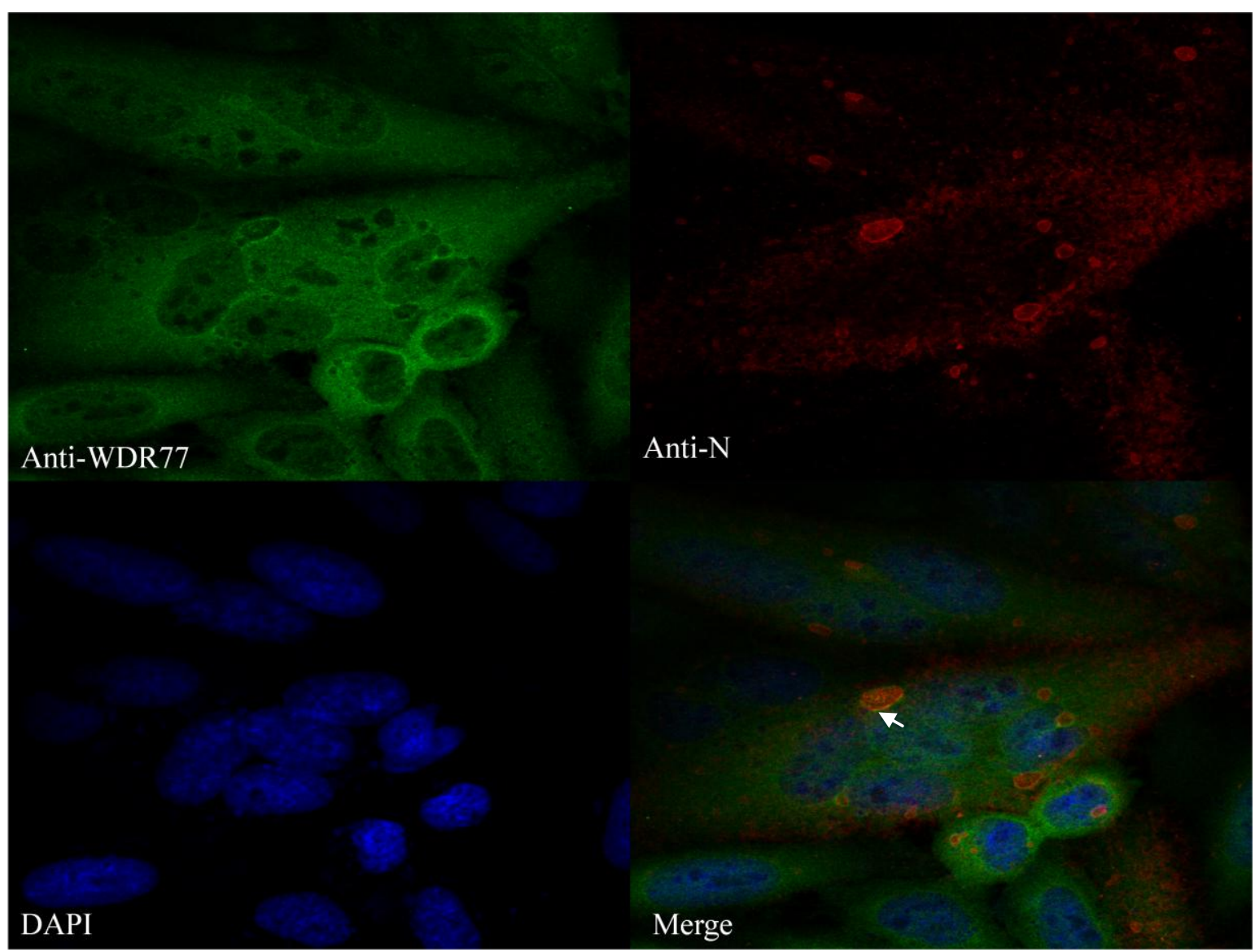

Células Hep-2 transfectadas com plasmídeo pcDNA-HA-WDR77, 24 hs depois foram infectadas e 24 hs pós-infecção foram fixadas com paraformaldeído 4\% e incubadas com anti-WDR77 e anti-N (Abcam ${ }^{\circledR}$, Cambridge, Reino Unido) e depois com os secundários anti-coelho e anti-camundongo (acoplados a Alexafluor-488 e 594, respectivamente, da Life Techonologies®, Califórnia, EUA) e os núcleos corados com DAPI. Estão apresentados os resultados da imunofluorescência detectada com microscópio Zeiss ${ }^{\circledR}$ LSM 780-NLO, Jena, Alemanha, e filtros apropriados. 
Figura 20 - Co-localização da WDR77, PRMT5 e N por imunofluorescência confocal.

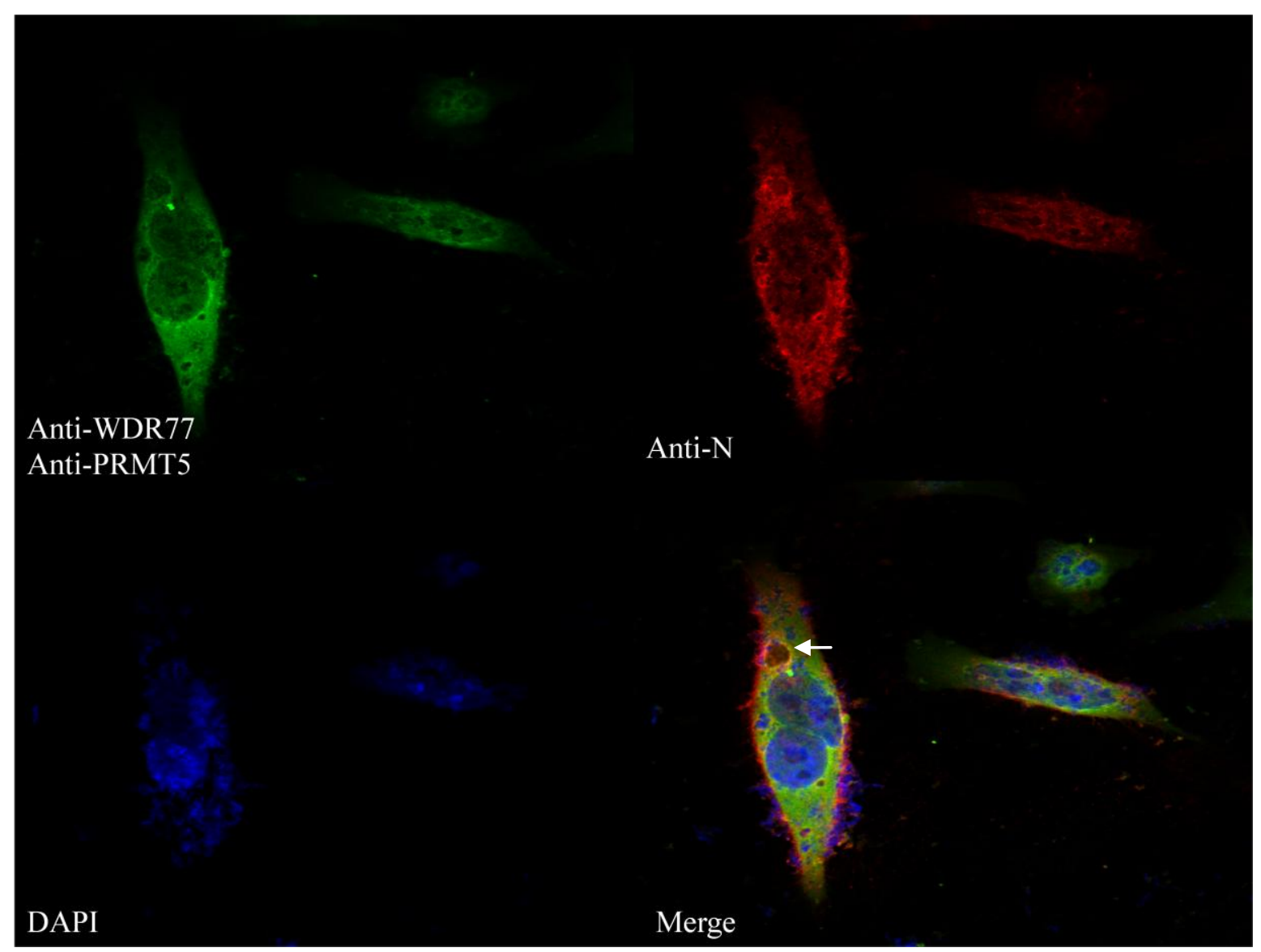

Células Hep-2 transfectadas com plasmídeo pcDNA-HA-PMRT5 e pcDNA-HA-WDR77, 24 hs depois foram infectadas e 24 hs pós-infecção foram fixadas com paraformaldeído $4 \%$ e incubadas com anti-PRMT5, anti-WDR77 e anti-N (Abcam®, Cambridge, Reino Unido) e depois com os secundários anti-coelho e anti-camundongo (acoplados a Alexafluor-488 e 594, respectivamente, da Life Techonologies ${ }^{\circledR}$, Califórnia, EUA) e os núcleos corados com DAPI. Estão apresentados os resultados da imunofluorescência detectada com microscópio Zeiss® LSM 780-NLO, Jena, Alemanha e filtros apropriados.

\subsection{Inibição da PRMT5 por si RNA e seu efeito na replicação viral}

No sentido de buscar significado funcional para essa interação analisamos o efeito da inibição da expressão de PRMT5 na replicação viral. Primeiramente foram realizados experimentos com diferentes concentrações de siRNA tanto em Hep-2 quanto em HEK293T. Nos experimentos iniciais com $5 \mathrm{nM}, 10 \mathrm{nM}$ e $20 \mathrm{nM}$ de siRNA, nenhuma inibição foi observada (resultado não apresentado). Então foi feito um teste em HEK293T, devido ao tipo celular apresentar melhores resultados em experimentos de transfecção, com $50 \mathrm{nM}$ ou 100 nM de siRNA contra a PRMT5, seguida de infecção (ver item 3.7). Pode-se observar que 
houve inibição em torno de $50 \%$ (Figura 21, canaletas 1 e 2 x o controle na 3) da PRMT5 no blot com anticorpo anti-PRMT5. Outro western blotting foi feito com as mesmas amostras, desta vez revelado com anti-N, onde não observamos inibição na replicação viral em relação aos controles (Figura 22).

Figura 21 - Teste siRNA PRMT5 50nM e 100nM.

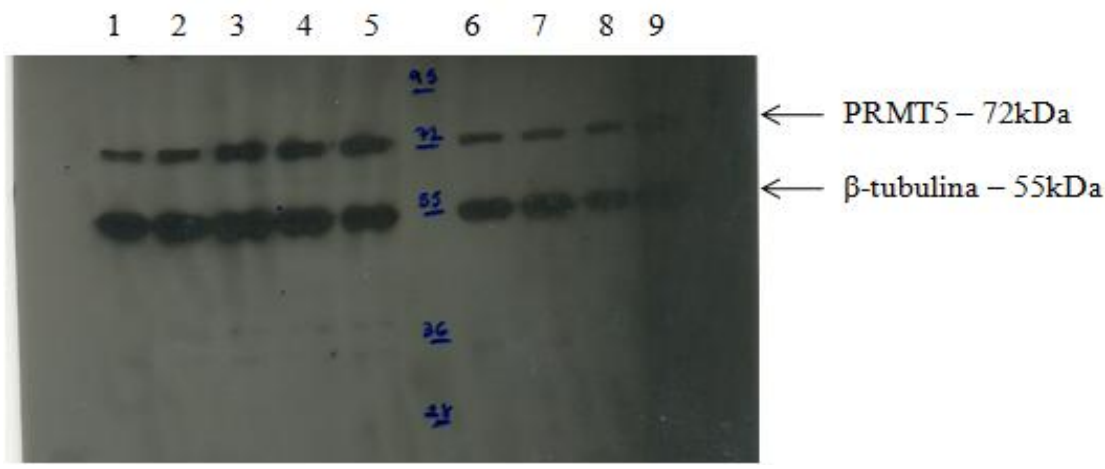

Western blotting do gel de SDS-PAGE 10\%. Transfecção de 50nM e 100nM de siRNA (Qiagen®, Hilden, Alemanha) em HEK293T, infectado, e transfectado novamente (com as mesmas concentrações) 3 hs pós infecção. Análise feita com anti-PRMT5 e anti- $\beta$ Tubulina (Abcam®, Cambridge, Reino Unido). 1 - 50nM de siRNA + HRSV; 2 - 100nM de siRNA + HRSV; 3 100nM Scramble + HRSV; 4 - meio MEM com Lipofectamina + HRSV; 5 - Meio MEM + HRSV; 6 - 50nM siRNA; 7 - 100nM de siRNA; 8 - 100nM Scramble; 9 - meio MEM com Lipofectamina.

Figura 22 - Efeito do siRNA PRMT5 na replicação viral.

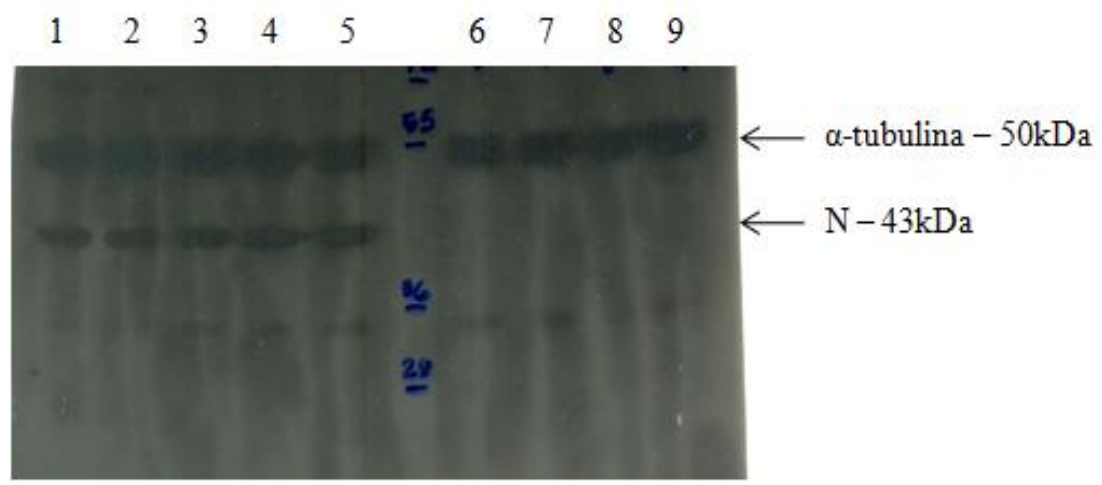

Western blotting do gel de SDS-PAGE 10\%. Transfecção de 50nM e 100nM de siRNA (Qiagen $®$, Hilden, Alemanha) em HEK293T, infectado, e transfectado novamente 3 hs pós infecção. Análise feita com anti- $\alpha$ tubulina e anti-N (ambos Abcam ${ }^{\circledR}$, Cambridge, Reino Unido). 1 - 50nM de siRNA + HRSV; 2 - 100nM de siRNA + HRSV; 3 - 100nM Scramble + HRSV; 4 - meio MEM com Lipofectamina + HRSV; 5 - Meio MEM + HRSV; 6 - 50nM siRNA; 7 - 100nM de siRNA; 8 100nM Scramble; 9 - meio MEM com Lipofectamina. 
Em outro experimento, chegamos a transfectar 200nM de siRNA com melhora da inibição de PRMT5 em células HEK293T, porém nenhuma inibição nos níveis de replicação viral foi observada (não apresentado). Além desse siRNA obtido da Qiagen®, Hilden, Alemanha, testamos outro sintetizado pela empresa Life Technologies®, Califórnia, EUA (ver item 3.7), e também não obtivemos sucesso em evidenciar efeito sobre a replicação viral (não apresentado).

\subsection{Superexpressão da PRMT5 elou WDR77 e seu efeito na replicação viral}

Testamos também qual seria o efeito da superexpressão da PRMT5 e/ou WDR77 sobre a replicação viral em células infectadas. Este dado seria um contraponto à inibição tanto por siRNA (acima) ou por inibidores (adiante). Para isso, células Hep-2 foram transfectadas com pcDNA-HA-PRMT5 e/ou pcDNA-HA-WDR77, 24 hs depois infectadas, e 48 hs pós infecção foram coletadas. A análise por western blotting (figura 23A) indica que a transfecção da PRMT5 resultou em aumento expressivo de proteína, o que não foi evidenciado para WDR77. A replicação viral monitorada pela expressão de $\mathrm{N}$, no entanto, não foi afetada significativamente (figura 23B). Resultado similar foi obtido em células HEK293 (não apresentado).

Figura 23 - Superexpressão das proteínas celulares e seu efeito na replicação viral.

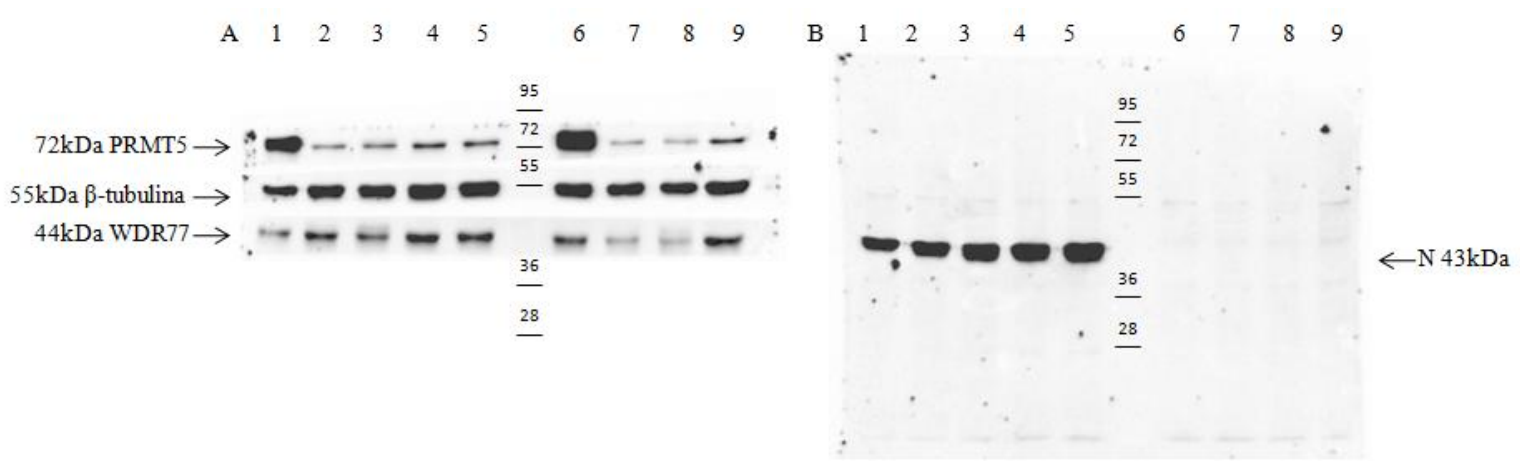

Células Hep-2 foram transfectadas com os plasmídeos pcDNA-HA-PRMT5 e/ou pcDNA-HAWDR77 $(0,5 \mu \mathrm{g}$ de DNA por poço da placa de multiwell de 24 poços). 24 hs depois foram infectadas e 24 hs pós-infecção foram coletadas e analisadas por western blotting. Anticorpos primários contra: A - WDR77, PRMT5, $\beta$-tubulina; B - $\alpha$-N, $\alpha$-tubulina; e secundário anti-coelho (todos da Abcam ${ }^{\circledR}$, Cambridge, Reino Unido). Amostras na ordem: 1- Transfectado com pcDNAHA-PRMT5 + HRSV; 2 - Transfectado com pcDNA-HA-WDR77 + HRSV; 3 - Transfectado com pcDNA-HA-PRMT5 + pcDNA-HA-WDR77 + HRSV; 4 - Meio MEM com Lipofectamina + HRSV; 5 - Meio MEM + HRSV; 6 - Transfectado com pcDNA-HA-PRMT5; 7 - Transfectado com pcDNA-HA-WDR77; 8 - Transfectado com pcDNA-HA-PRMT5 + pcDNA-HA-WDR77; 9 Meio MEM com Lipofectamina. 


\subsection{Análise de metilação na proteína $N$}

Segundo Sparkman (2000), a análise por espectrometria de massas permite identificar proteínas presentes em uma amostra e se existe alguma modificação pós-traducional, por exemplo a metilação, esta pode ser detectada. Num experimento preliminar, enviamos a banda de $\mathrm{N}$ obtida em gel preparativo (não apresentado) da imunoprecipitação apresentada à figura 6 (canaleta 3) ao CEFAP-ICB-USP (ver item 3.11). Como esperado, a identificação da $\mathrm{N}$ foi positiva com um grau de cobertura que permite a análise dos peptídeos gerados em busca de alterações que indiquem metilação (não apresentado). No entanto, como essa abordagem não é usual para o pessoal do CEFAP, acabamos tendo apenas indicativo de presença de metilação, mas que foi suficiente para nos dar um estímulo a buscar outros recursos de análise.

\subsubsection{Análise de metilação na proteína FLAG-N expressa por transfecção}

Como dispomos no laboratório do vetor pcDNA3-FLAG-N, que foi utilizado nos achados de interação iniciais dos trabalhos de Simabuco (2009) e Oliveira et al. (2013), e pelo fato da imunoprecipitação com anti-Flag ser muito eficiente, resolvemos tentar a análise inicialmente na proteína FLAG-N. Depois de re-amplificar esse plasmídeo a partir dos estoques, foram feitas transfecções, tanto em Hep-2 quanto em HEK293T e com diferentes reagentes (PEI, Lipofectamina 2000 e Lipofectamina PLUS, ver item 3.5), para confirmar a expressão (resultados não apresentados).

Depois de verificar que as células expressam a proteína FLAG-N, foi feita outra transfecção em larga escala em células HEK293T. Neste experimento utilizamos beads antiFLAG (Sigma ${ }^{\circledR}$, Missouri, EUA), que dão uma maior especificidade e melhor eficiência à imunoprecipitação de proteínas em fusão com o peptídeo FLAG. A análise por Western Blotting mostrou que as beads realmente capturaram a proteína FLAG-N (figura 24). Tivemos um problema metodológico devido à indisponibilidade de peptídeo FLAG, naquele momento, para fazer a eluição da proteína presa às beads. Assim, ao ferver a amostra para aplicar no gel, temos a liberação das cadeias de anticorpos anti-Flag que estavam presos às beads, e sua detecção (bandas acima e abaixo de $\mathrm{N}$ ) pelo secundário utilizado no western blot. 
Figura 24 - Imunoprecipitação de FLAG-N.

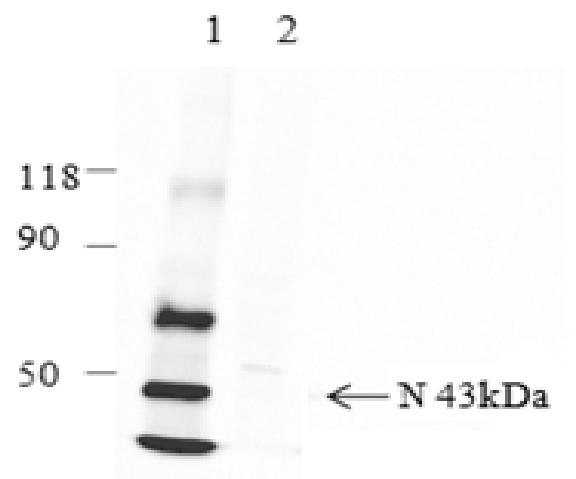

\begin{abstract}
A transfecção foi feita com Lipofectamina PLUS em células HEK293T, e após imunoprecipitação com beads de agarose acoplados a anticorpo anti-FLAG (Sigma ${ }^{\circledR}$, Missouri, EUA), foi feito western blot (gel $10 \%$ de poliacrilamida) com anticorpo primário anti-N (Abcam®, Cambridge, Reino Unido). Transfecção com: 1 - pcDNA3-FLAG-N, 2 - pcDNA3-FLAG- $\varnothing$ (vetor vazio). À esquerda marcador de peso molecular (Fermentas $®$, Califórnia, EUA).
\end{abstract}

Numa primeira tentativa de caracterizar a metilação na proteína FLAG-N, utilizamos anticorpos anti-arginina metilada ou di-metilada adquiridos da Abcam®, Cambridge, Reino Unido (item 3.2). Como pode ser observado à figura 25, temos um indicativo de detecção pelos dois anticorpos. Pode-se observar que na altura da proteína FLAG-N, foram detectadas tanto arginina metilada quanto di-metilada. Consideramos que as bandas extras detectadas são devidas ao processo de fervura das beads, como argumentado acima.

Figura 25 - Detecção de metilação em FLAG-N.
A
12
B

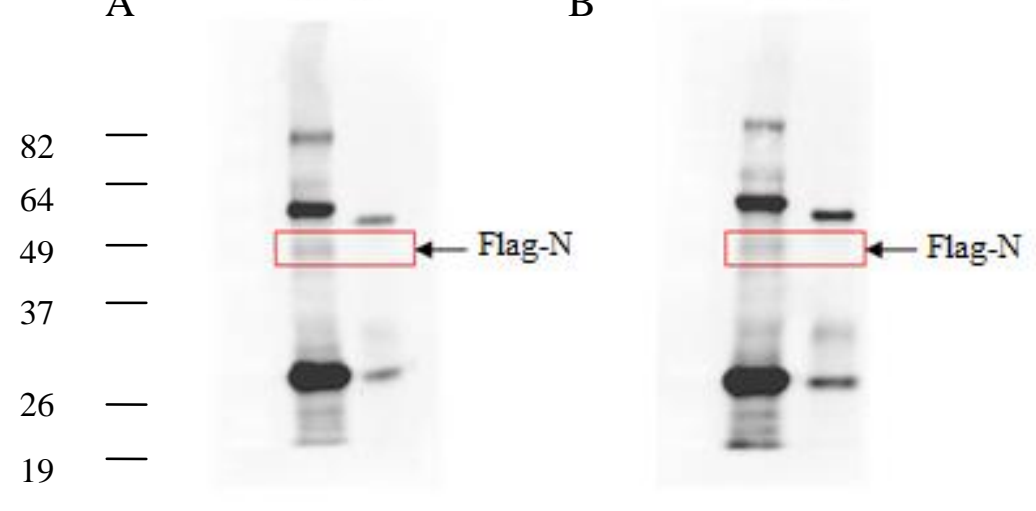

Após a transfecção foi feita imunoprecipitação com anti-flag acoplada à beads de agarose de células HEK293T transfectadas. Western blotting do gel de SDS-PAGE $10 \%$ com anticorpos primários contra arginina metilada (A) e di-metilada (B) (ambos adquiridos da Abcam®, Cambridge, Reino Unido, ver item 3.4). Transfecção com (1) pcDNA-FLAG-N ou (2) pcDNAFLAG-Ø. À esquerda marcador de peso molecular (Life Thechnologies®,Califórnia, EUA). 
Com a indicação de metilação da proteína FLAG-N, um gel preparativo de SDSPAGE $10 \%$ foi feito com esta mesma amostra e corado com Coomassie Blue. O resultado (figura 26) mostra a banda com peso molecular correspondente à FLAG-N. Análise com o programa ImageJ indica que ao comparar a banda de BSA, com quantidade de proteína conhecida (3 $\mu \mathrm{g}$ ), pode-se inferir que a amostra de FLAG-N presente no gel é de aproximadamente $1 \mu \mathrm{g}$. Esta foi cortada e enviada para análise por espectrometria de massas para confirmar se há metilação, em um serviço especializado fornecido pela MSBioworks nos Estados Unidos (ver item 3.11).

Figura 26 - Gel preparativo de FLAG-N.

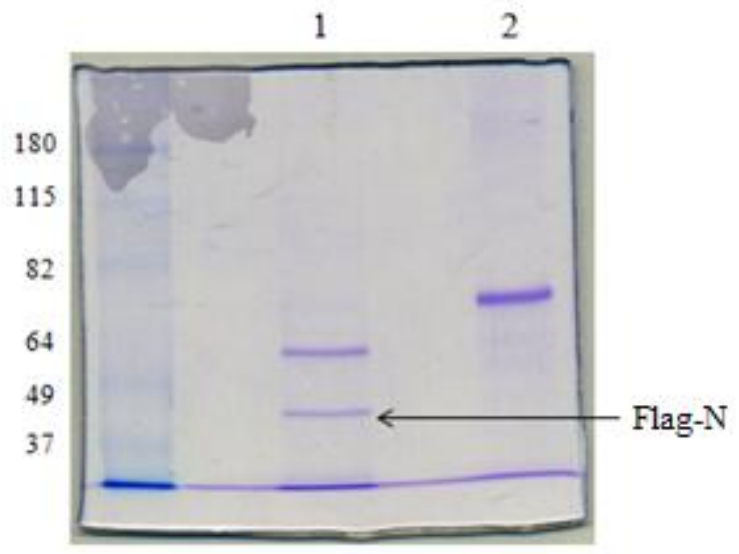

O resultado da imunoprecipitação da proteína FLAG-N com anti-FLAG beads, foi submetido a SDS-PAGE $10 \%$ preparativo e corado com Coomassie Blue. A seta indica a banda correspondente à proteína FLAG-N. 1 - imunoprecipitação da FLAG-N; 2 - $3 \mu \mathrm{g}$ de BSA (Sigma®, Missouri, EUA) para comparação de peso molecular e quantidade de proteína FLAG$\mathrm{N}$ obtidos. À esquerda marcador de peso molecular (Life Thechnologies ${ }^{\circledR}$, Califórnia, EUA).

Pelo protocolo PTM-Profiling plus, aplicado pela MSBioworks, Michigan, EUA, foram encontrados resíduos dos aminoácidos lisina e arginina metilados com alto grau de confiabilidade, como indicado na tabela 1. 
Tabela 1 - Análise de FLAG-N por espectrometria de massas.

\begin{tabular}{cccc}
\hline Resíduo & Local & Modificação & Melhor Ascore \\
\hline K & 42 & Metil & $1,000.00$ \\
K & 46 & Metil & $1,000.00$ \\
R & 150 & Metil & $1,000.00$ \\
K & 293 & Metil & $1,000.00$ \\
K & 358 & Metil & $1,000.00$ \\
\hline
\end{tabular}

É interessante notar que os resíduos K42, K46 e R150 estão localizados próximos ao sítio de interação com a proteína P (figura 27) (GALLOUX et al., 2012). As lisinas K293 e K358, por sua vez, também estão posicionadas em local que pode ter significado, próximo ao domínio de $\mathrm{N}$ que faz interação com o RNA viral (figura 28).

Figura 27 - Imagem de um detalhe da estrutura 3D da proteína N com indicação das posições metiladas próximas ao sítio de interação com P.

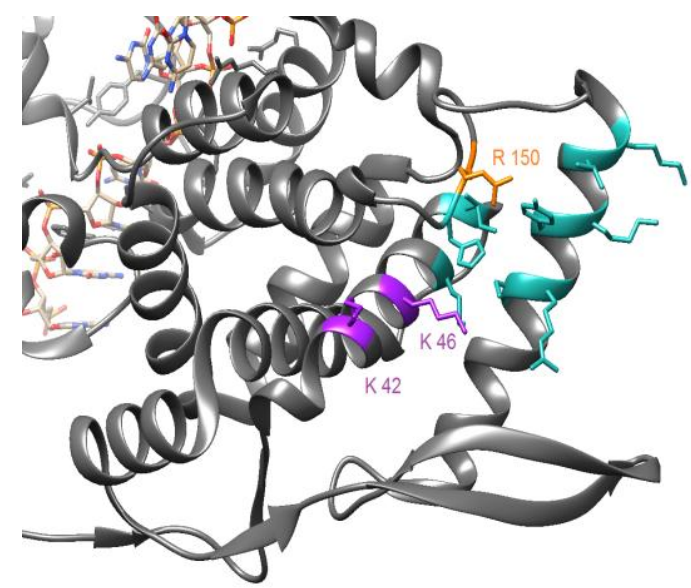

Estão apresentadas figuras de detalhes da estrutura de N, geradas pelo programa Chimera (obtido no site da UCSF), com o PDB 2WJ8 (Tawar et al, 2009). O backbone de $\mathrm{N}$ está indicado em cinza escuro e um trecho de sete bases de RNA associado em laranja/azul/branco. Os resíduos que compõem o sítio de ligação a $\mathrm{P}$ estão em verde. Locais dos resíduos metilados encontrados na proteína FLAG-N obtida por imunoprecipitação com anti-flag acoplado a beads, em lisados de células HEK293T transfectadas com pcDNA-FLAG-N. Em roxo as lisinas K42 e K46, e em laranja a arginina R150. 
Figura 28 - Imagem da estrutura 3D da proteína $\mathrm{N}$ com indicação das posições metiladas próximas ao domínio de ligação ao RNA.

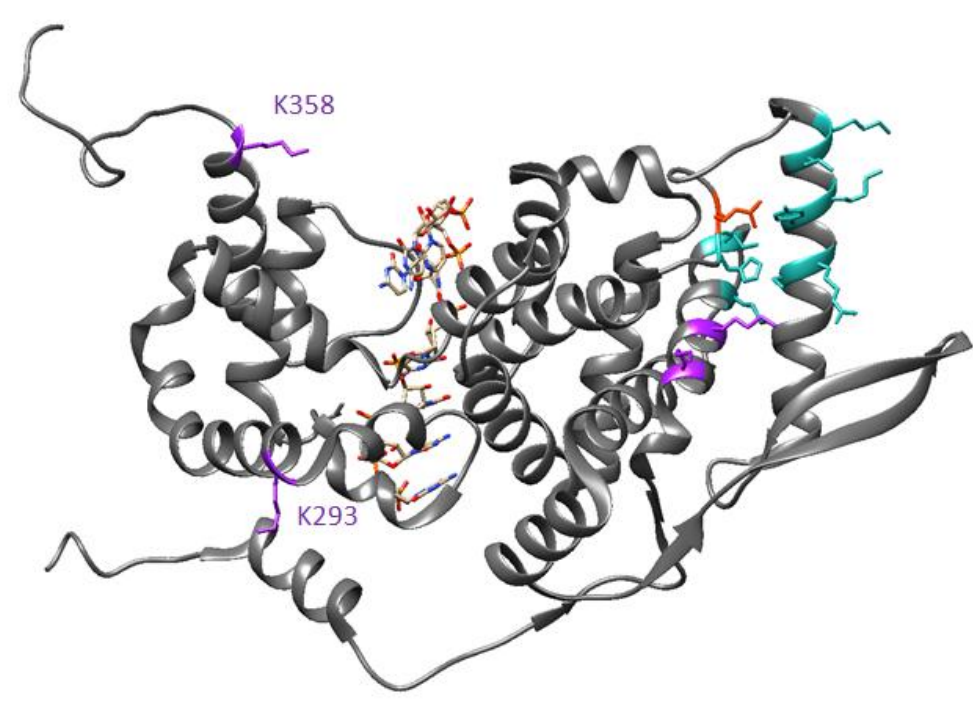

Está apresentada imagem de toda a proteína $\mathrm{N}$, obtida conforme a descrição na legenda da figura 28. Em destaque as lisinas K358 e K293, próximas do local de interação com o RNA viral.

\subsubsection{Análise de metilação da proteína N viral}

Na análise da proteína FLAG-N obtida por transfecção tem-se uma super expressão, não necessariamente mimetizando o que acontece naturalmente, por isso resolvemos analisar a proteína N viral. Para obter massa suficiente para análise, células Hep-2 (duas garrafas de 175 $\mathrm{cm}^{2}$ ) foram infectadas com HRSV e coletadas após $48 \mathrm{hs}$. As amostras foram processadas para imunoprecipitação, imunoprecipitadas com anti-N monoclonal (Abcam) e a banda correspondente a $\mathrm{N}$ foi cortada de gel preparativo corado com Coomassie Blue (não apresentado) e enviada para análise por espectrometria de massas pela MSBioworks, Michigan, EUA. À tabela 2 e à figura 29 estão indicados os resíduos onde foram encontradas metilações. 
Tabela 2 - Análise da proteína N por espectrometria de massas

\begin{tabular}{cccc}
\hline Resíduo & Local & Mdificação & Ascore \\
\hline $\mathbf{K}$ & 07 & Metil & 190,97 \\
$\mathbf{K}$ & 14 & Metil & 178,72 \\
$\mathbf{K}$ & 22 & Metil & 187,72 \\
$\mathbf{K}$ & 42 & Metil & $1.000,00$ \\
$\mathbf{K}$ & 46 & Metil & 209,58 \\
$\mathbf{R}$ & 101 & Metil & 40,26 \\
$\mathbf{R}$ & 150 & Metil & $1.000,00$ \\
$\mathbf{K}$ & 308 & Metil & $1.000,00$ \\
$\mathbf{K}$ & 351 & Metil & $1.000,00$ \\
$\mathbf{K}$ & 358 & Metil & $1.000,00$ \\
\hline
\end{tabular}

Figura 29 - Imagem da estrutura 3D da proteína N com indicação das posições metiladas.

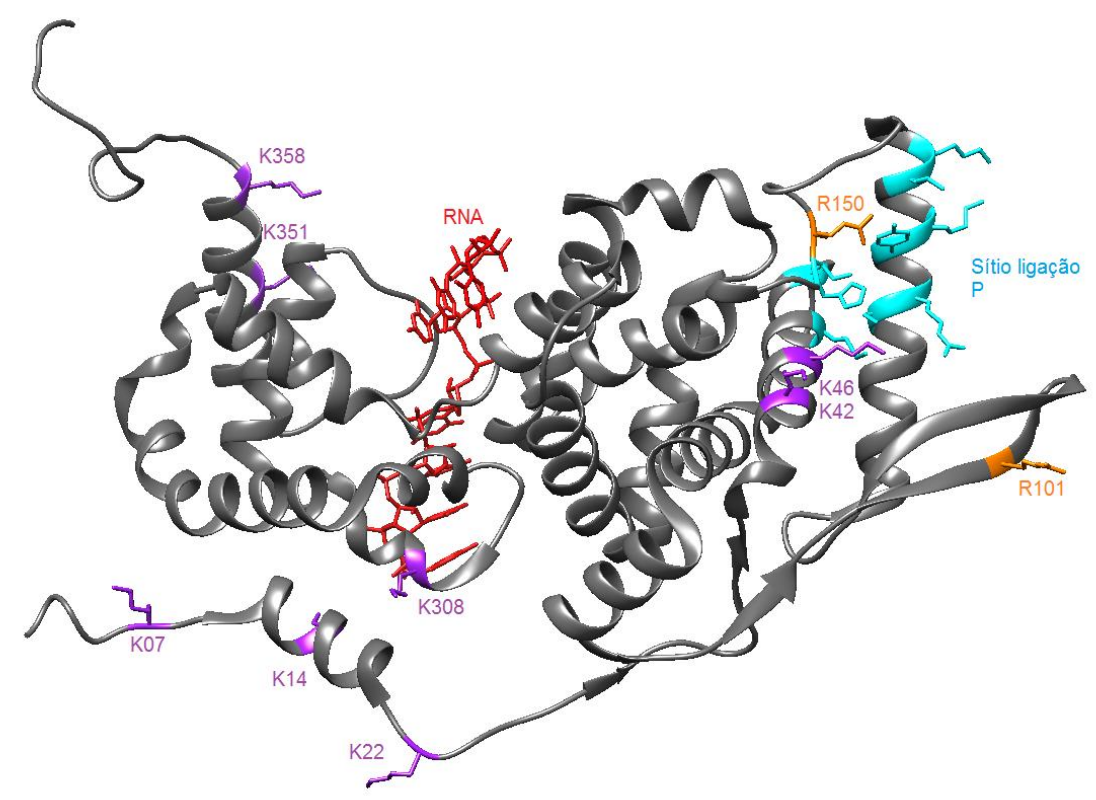

Está apresentada a estrutura em 3D da proteína $\mathrm{N}$ obtida por ultracentrifugação do vírus, gerada pelo programa Chimera (obtido no site da UCSF), com o PDB 2WJ8 (Tawar et al, 2009). O backbone de $\mathrm{N}$ está indicado em cinza escuro e um trecho de sete bases de RNA associado em vermelho. Os resíduos que compõem o sítio de ligação a P estão em verde. Em roxos os locais de lisina metilada K07, K14, K22, K42, K46, K308, K351 e K358. Em laranja argininas metiladas, R101 e R150. 
Assim como na análise da proteína FLAG-N, diversos resíduos de lisinas e agora dois de arginina têm indicação de metilação. As lisinas nas posições 42, 46 e 358 apareceram também na análise da FLAG-N, sendo que 42 e 358 obtiveram ascore máximo nas duas análises. Do mesmo modo da análise anterior onde os resíduos metilados estão próximos a locais interessantes, nesta análise os resíduos também se encontram próximos ao sítio de interação com a P e próximos ao local de interação com o RNA.

Para confirmar que a $\mathrm{N}$ está metilada em lisina, adquirimos um anticorpo anti-lisina metilada (Sigma ${ }^{\circledR}$, Missouri, EUA) e foi feito um western botting com amostra de vírus ultracentrifugado, extrato celular infectado e não infectado (Figura 30).

Figura 30 - Analise da metilação em lisina por western blotting.

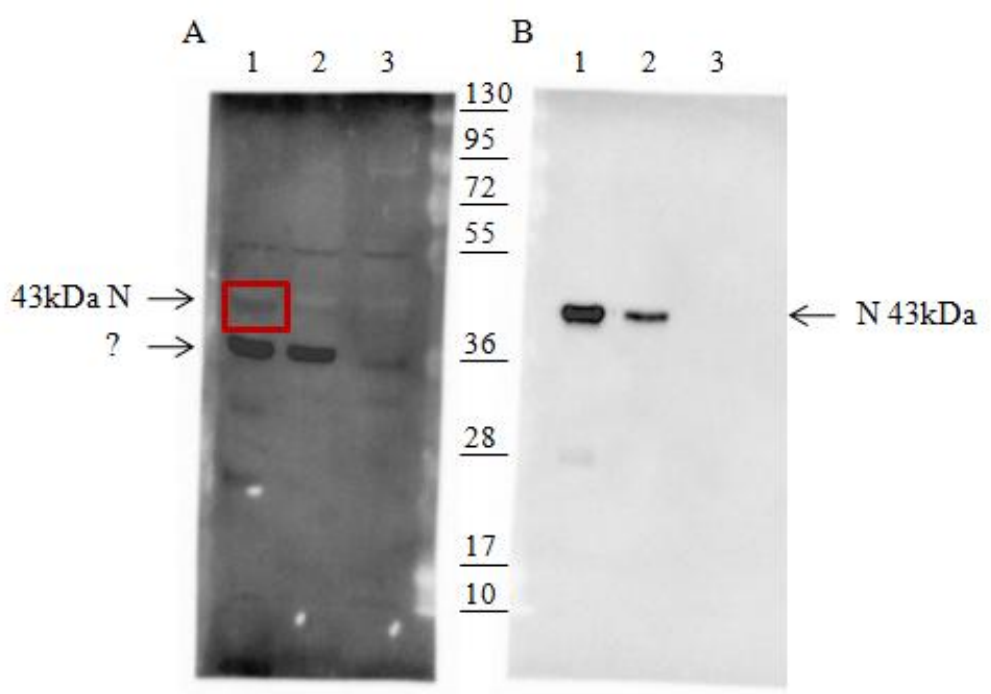

Está apresentado western blotting para verificar a presença de metilação em lisina nas amostras: 1 - vírus purificado por ultracentrifugação; 2 - extrato celular infectado; 3 - extrato celular não infectado; western blot revelado com A - anti-Lisina metilada ou B - anti-N.

Às canaletas 1 e 2 da figura 30 é possível observar uma banda fraca na membrana revelada com anti-lisina metilada na altura da $\mathrm{N}$ (em destaque). Esse padrão é similar ao que observamos com os anticorpos anti-metil arginina, e pode indicar que a modificação não está presente em todas as moléculas de $\mathrm{N}$.

Interessantemente, na altura correspondente à proteína $\mathrm{P}$, observou-se que que haviam bandas fortes tanto na amostra do vírus ultracentrifugado quanto no extrato celular infectado, o que pode indicar que não somente a $\mathrm{N}$ estaria sendo metilada, mas outras proteínas do vírus ou da célula no contexto da infecção viral. Analisamos extratos de células infectadas de 
experimentos anteriores, e a presença dessas bandas fortemente reativas com anti-lisina metilada foi confirmada (dado não apresentado).

Como a reatividade do anticorpo anti-metil lisina foi claramente maior em células infectadas (figura 30 canaleta 2 x 3), resolvemos testar esse anticorpo em imunofluorescência contra células infectadas e não infectadas. Foi feito um experimento em células Hep-2 fixadas 36 hs depois da infecção. As células foram fixadas e incubadas com anti-metil lisina e anti-N. Como pode ser observado na figura 31 , o padrão de marcação com anti-metil lisina é bem diferente em células infectadas havendo um aumento significativo de pontos de concentração da marcação. À figura 32, ao sobrepor as marcações de anti-N e anti-metil lisina, há uma indicação de co-localização do corpúsculo de inclusão com os locais de concentração de lisina metilada em boa parte das células infectadas.

Figura 31 - Imunofluorescência da lisina metilada em célula não infectada.

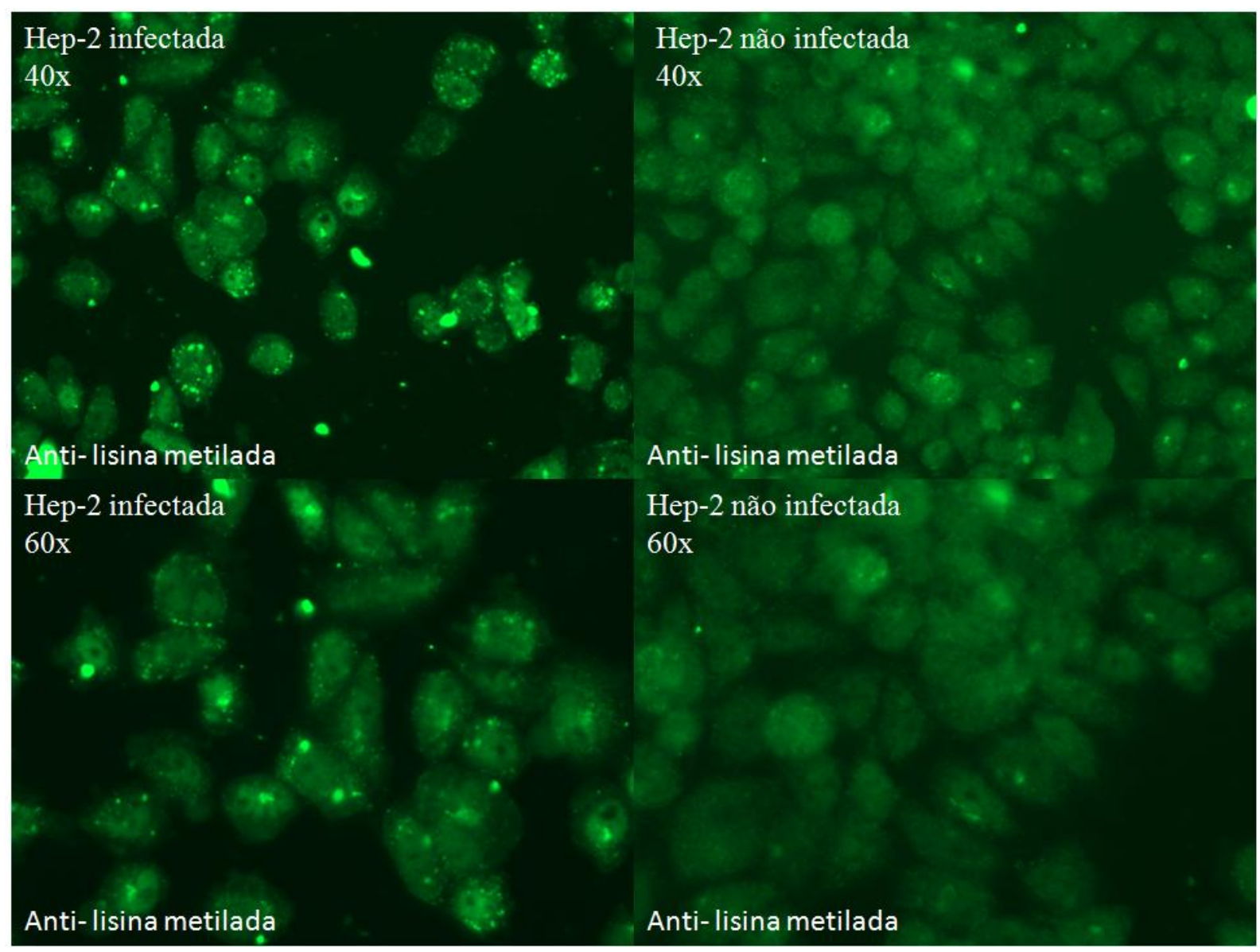

Células Hep-2 infectada x não infectada, fixada e incubada com anti-metil lisina metilada e depois com os secundários anti-coelho (acoplados a Alexafluor-488, da Life Techonologies ${ }^{\circledR}$, Califórnia, EUA). Estão apresentados os resultados da imunofluorescência detectada com microscópio Zeiss ${ }^{\circledR}$, Jena, Alemanha, e filtro apropriado para verificar distribuição natural de lisinas metiladas em Hep-2. 
Figura 32 - Imunofluorescência da co-localização de lisina metilada e N.

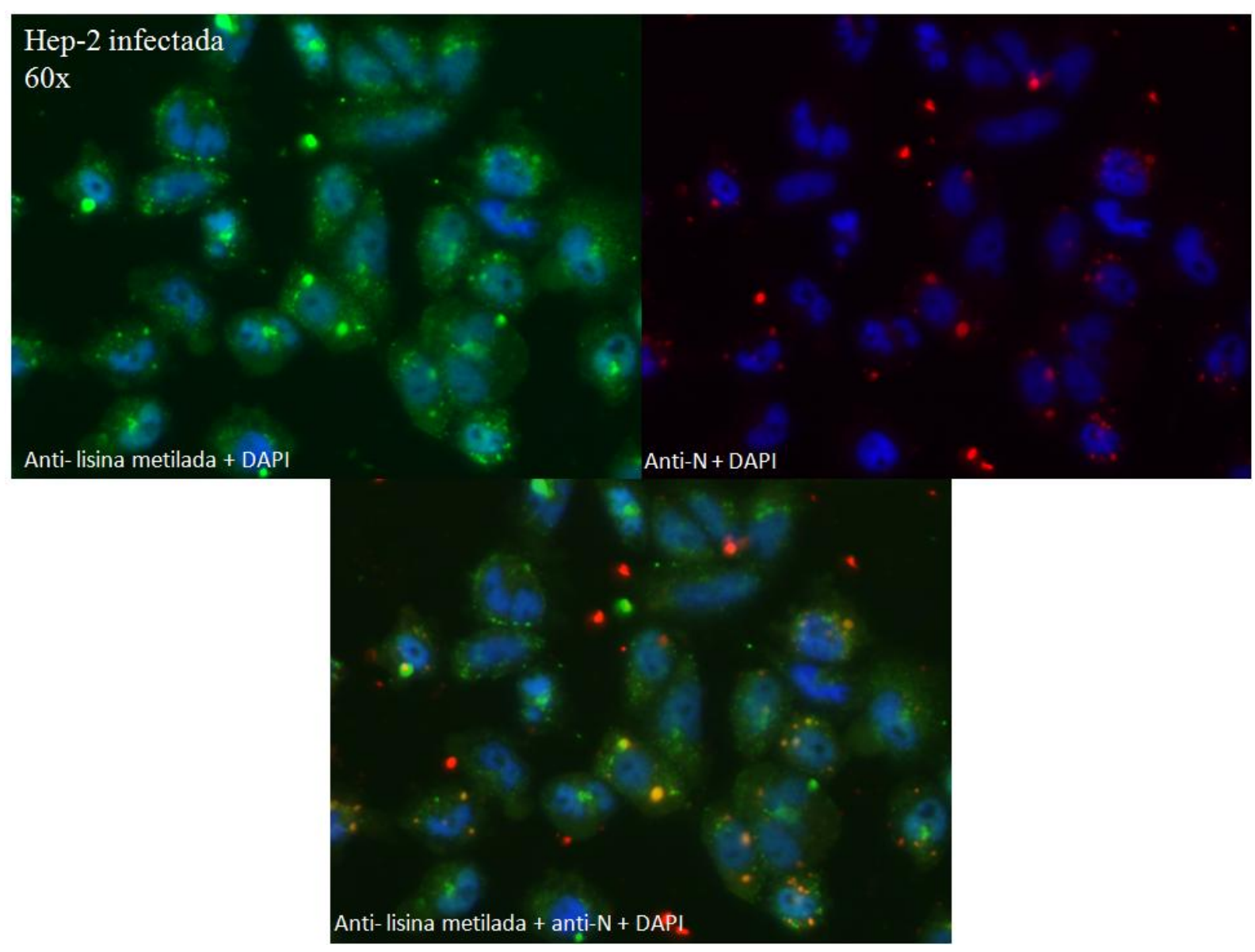

Células Hep-2 infectada, fixada e incubada com anti-metil lisina metilada e anti-N e depois com os secundários anti-coelho e anti-camundongo (acoplados a Alexafluor-488 e 594, respectivamete, da Life Techonologies ${ }^{\circledR}$, Califórnia, EUA) e os núcleos corados com DAPI. Estão apresentados os resultados da imunofluorescência detectada com microscópio Zeiss®, Jena, Alemanha e filtros apropriados.

4.8 Efeito de inibidores de metilação e demetilação na replicação viral

Depois de confirmada a metilação na proteína $\mathrm{N}$, nos propusemos a testar se outra forma de inibição da PRMT5, diferente do siRNA apresentado acima, poderia influenciar na eficiência de replicação do vírus. Como além da metilação em argininas, esperada pela interação N-metilosomo, encontramos também metilação em lisinas, investimos em inibidores dos das duas modificações. Incluímos também um inibidor de demetilação em arginina, assumindo um modelo de que esse processo seria dinâmico. 


\section{$\underline{\text { 4.8.1 Inibidor de metilação em arginina pela PRMT5 }}$}

Depois de confirmada a metilação na proteína $\mathrm{N}$, nos propusemos a testar se outra forma de inibição da PRMT5, diferente do siRNA apresentado acima, poderia influenciar na eficiência de replicação do vírus. Investimos num inibidor específico da PRMT5, o EPZ015666 (CHAN-PENEBRE et al., 2015). Primeiramente foi feito um teste de toxicidade em células Hep-2, onde as células foram incubadas por 4 dias com $1 \mu \mathrm{M}, 5 \mu \mathrm{M}, 10 \mu \mathrm{M}$, 0,2 \% de DMSO (controle do solvente), todos em meio MEM $2 \%$ de SFB, além do controle somente meio MEM $2 \%$ de SFB. Então as células foram fixadas e coradas com cristal violeta para verificar a toxicidade do inibidor. Podemos observar que a toxicidade aumentou gradativamente com o aumento da concentração do inibidor (figura 33). Para os experimentos seguintes decidimos utilizar $1,5 \mu \mathrm{M}$ e $3 \mu \mathrm{M}$, na tentativa de evidenciar um efeito sobre a replicação viral.

Figura 33 - Teste de toxicidade do EPZ015666 em Hep-2.

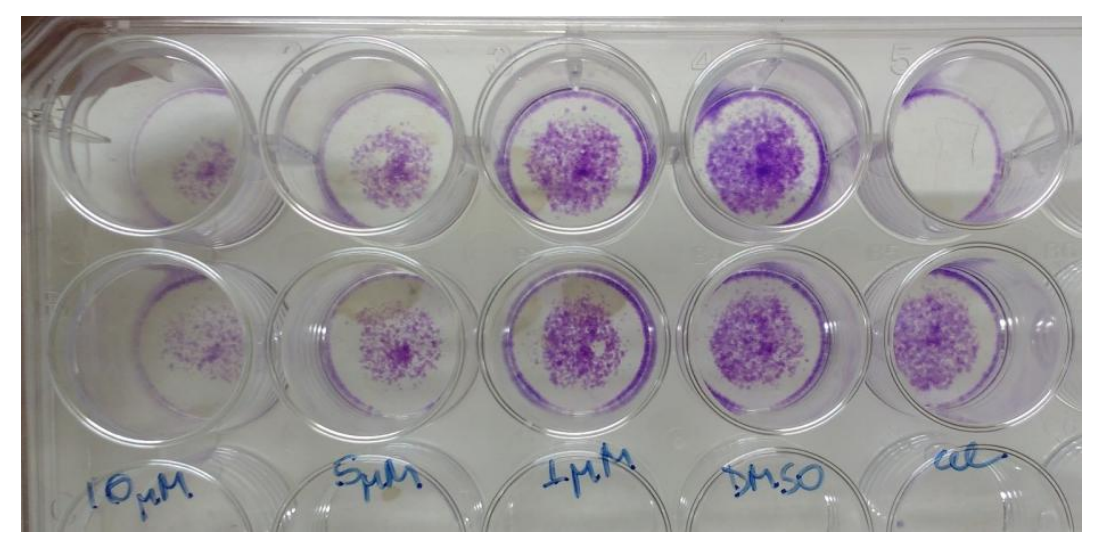

Células Hep-2 foram incubadas com $10 \mu \mathrm{M}, 5 \mu \mathrm{M}, 1 \mu \mathrm{M}$ de EPZ015666 (Cayman Chemicals, Michigan, EUA), em meio MEM com 0,2 \% de DMSO ou somente meio MEM (respectivamente, em duplicata) por 96 hs. Em seguida as células foram fixadas com metanol gelado e coradas com cristal violeta $0,1 \%$.

Os mesmos testes foram feitos para células HEK293T. O resultado observado foi que não houve nenhuma alteração significativa na quantidade de células com o inibidor se comparado com o controle (Figura 34). Portanto foram escolhidas concentrações acima das concentrações utilizadas em Hep-2 para ter maior probabilidade de que o inibidor faria efeito na metilação. 
Figura 34 - Teste de toxicidade do EPZ015666 em HEK293T.

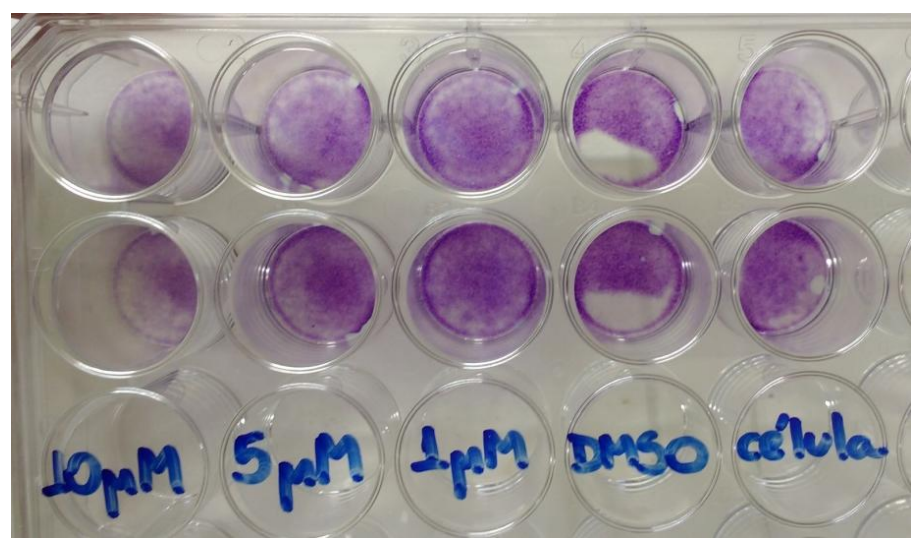

Células HEK293T foram incubadas com $10 \mu \mathrm{M}, 5 \mu \mathrm{M}, 1 \mu \mathrm{M}$ de EPZ015666 (Cayman Chemicals, Michigan, EUA), meio MEM com 0,2 \% de DMSO ou somente meio MEM (respectivamente, em duplicata) por 96 hs. Em seguida as células foram fixadas com metanol gelado e coradas com cristal violeta $0,1 \%$.

Então foram feitos experimentos de incubação dos inibidores seguido de infecção com HRSV. Para isso, as células foram incubadas com: 1,5 $\mu \mathrm{M}$ ou $3 \mu \mathrm{M}$ para Hep-2; $5 \mu \mathrm{M}$ ou $10 \mu \mathrm{M}$ para HEK293T (em meio $2 \%$ de SFB). Após 24 hs as células foram infectadas e coletadas em 30 hs pós-infecção, e analisadas por western blotting (Figura 35). Ao incubar células HEK293T com inibidor, nota-se que houve um pequeno aumento na intensidade da banda. Já em células Hep-2 a intensidade se manteve a mesma tanto nas células tratadas quanto nas células controle.

Figura 35 - Efeito do inibidor de metilação em arginina na infecção.

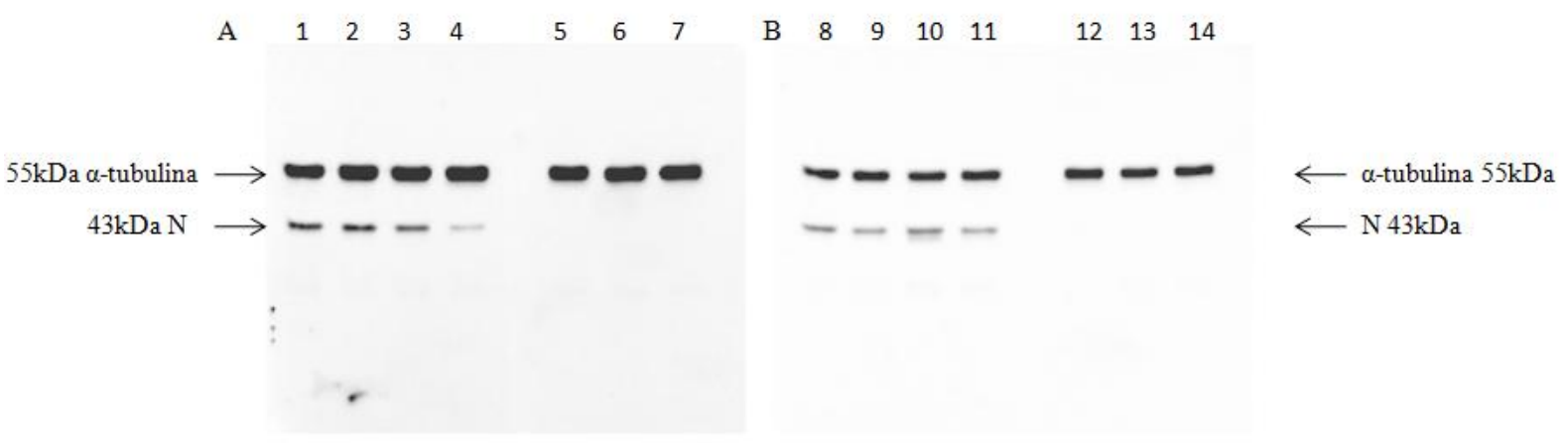

Está apresentado Western blotting, anti- $\alpha$-tubulina e anti-N (Abcam ${ }^{\circledR}$, Cambridge, Reino

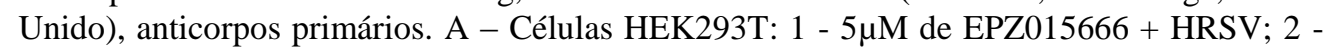
$10 \mu \mathrm{M}+$ HRSV; 3 - Meio com 0,2\% de DMSO + HRSV; 4 - Meio MEM + HRSV; 5 - $5 \mu \mathrm{M}$ de EPZ015666; 6 - Meio com 0,2\% de DMSO; 7 - Meio MEM. B - Células Hep-2: 8 1,5 $\mu \mathrm{M}$ de EPZ015666 + HRSV; $9-3 \mu \mathrm{M}$ de EPZ015666 + HRSV; 10 - Meio com 0,2\% de

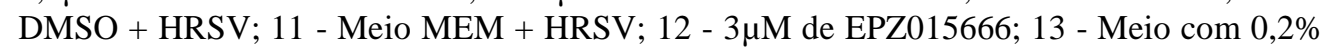
de DMSO; 14 - Meio MEM. 


\section{$\underline{\text { 4.8.2 Inibidor de demetilação de arginina }}$}

Liu et al., 2013 demonstraram que a PRMT5 interage com a demetilase JMJD6, por isso fizemos experimentos para verificar qual seria o efeito na replicação viral ao inibir a demetilação com o inibidor de JMJD6, NOG (Sigma®, Missouri, EUA, item 3.13). Células Hep-2 foram plaqueadas e incubadas com diferentes concentrações do inibidor: $5 \mathrm{mM}, 10$ mM e $20 \mathrm{mM}$ em meio MEM $2 \%$ de SFB e incubado por $48 \mathrm{hs}$, depois corado com cristal violeta para verificar o efeito tóxico do inibidor nas células (Figura 36). Mesmo na menor concentração do teste, $5 \mathrm{mM}$, a quantidade de células coradas foi cerca de $50 \%$ menor se comparado ao controle. Resolvemos testar a concentração de $2 \mathrm{mM}$ indicada no artigo de Lawrence; Conderino; Rieder (2014), além de 4 mM que não se mostraram tóxicos (dados não apresentados).

Figura 36 - Teste de toxicidade do NOG em Hep-2.

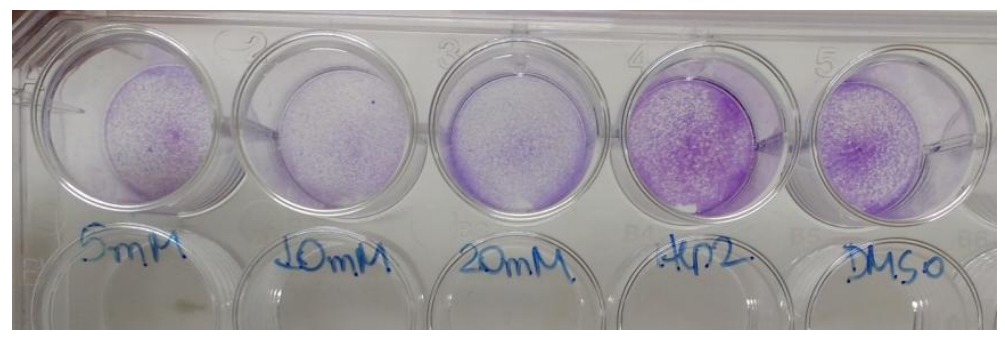

Células Hep-2 foram incubadas com $5 \mathrm{mM}, 10 \mathrm{mM}, 20 \mathrm{m \mu M}$, somente meio MEM ou com $0,2 \%$ de DMSO (respectivamente) por 48 hs. Em seguida as células foram fixadas com metanol gelado e coradas com cristal violeta $0,1 \%$.

Assim, células Hep-2 foram incubadas com $2 \mathrm{mM}$ ou $4 \mathrm{mM}$ de NOG por $24 \mathrm{hs}$, infectadas, e após 24 e 48 hs coletadas e analisadas por western blotting. O resultado está apresentado na figura 37 . Nenhum efeito na replicação viral pode ser observado. 
Figura 37 - Efeito de NOG na replicação viral.

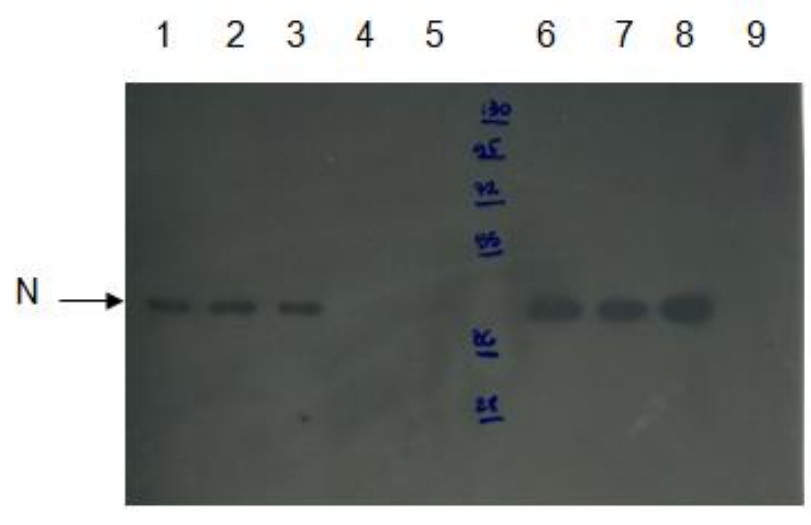

Está apresentado Western blotting do experimento com células Hep-2, tendo como anticorpo primário anti-N (Abcam ${ }^{\circledR}$, Cambridge, Reino Unido). células Hep-2 foram incubadas com $2 \mathrm{mM}$ ou $4 \mathrm{mM}$ de NOG por $24 \mathrm{hs}$, infectadas, e após 24 (amostras 1 a5) e 48 hs (amostras 6 a 9) coletadas. Amostra $1-2 \mathrm{mM}$ de NOG + HRSV; $2-4 \mathrm{mM}+\mathrm{HRSV} ; 3$ - Meio com $1 \%$ de DMSO + HRSV; $4-4 \mathrm{mM} ; 5$ - Meio com $1 \%$ de DMSO; 6 - $2 \mathrm{mM}+\mathrm{HRSV} ; 7-4 \mathrm{mM}+$ HRSV; 8 - Meio com $1 \%$ de DMSO; 9 - 4 mM.

\section{$\underline{4.8 .3 \text { Inibidores de metilação e demetilação de arginina em conjunto }}$}

Nos perguntamos então se haveria um efeito somatório dos inibidores. Para tanto, antes foi feito teste de toxicidade em Hep-2 e HEK293T, incubando o inibidor de metilação, EPZ015666 e o inibidor de demetilação, NOG, juntos. Diferentes concentrações foram testadas (Figura 38 e 39) por 48 hs, seguindo-se fixação e coloração com cristal violeta. Optou-se pela concentração de $3 \mu \mathrm{M}$ de EPZ015666 + 2 mM de NOG para Hep-2 e $10 \mu \mathrm{M}$ de EPZ015666 + 2 mM de NOG para HEK293T, pois nos dois casos a toxicidade afetou pouco o crescimento das células, indicando que seu efeito está presente, mas não o suficiente para atrapalhar o experimento. 
Figura 38 - Teste de toxicidade do duplo inibidor em Hep-2.

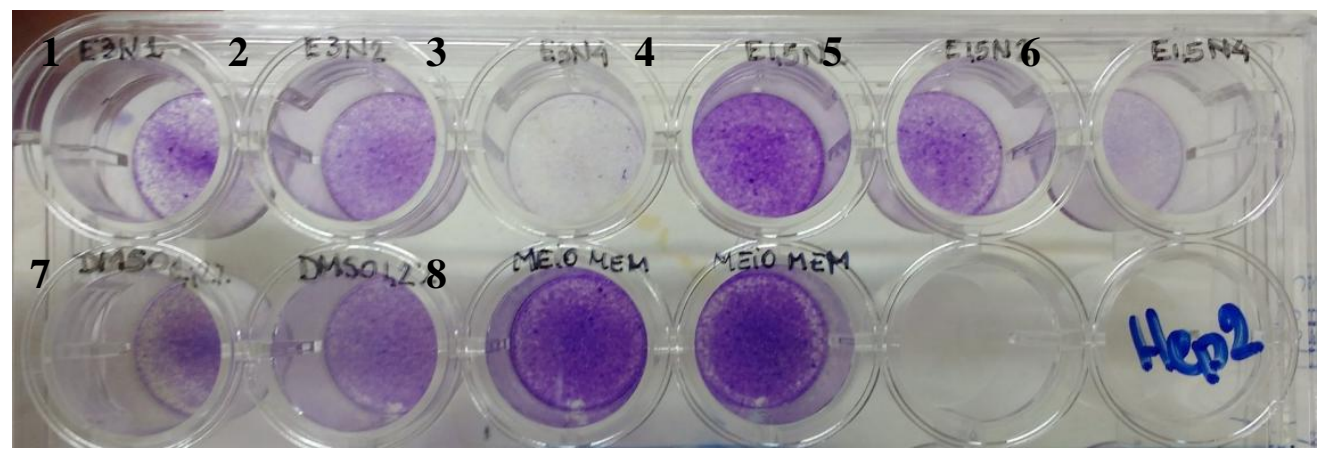

Células Hep-2 foram incubadas com: $1-3 \mu \mathrm{M}$ de EPZ015666 + $1 \mathrm{mM}$ de NOG; $2-3 \mu \mathrm{M}$ de EPZ015666 + $2 \mathrm{mM}$ de NOG; 3- $3 \mu \mathrm{M}$ de EPZ015666 + $4 \mathrm{mM}$ de NOG; $4-1,5 \mu \mathrm{M}$ de EPZ015666 + $1 \mathrm{mM}$ de NOG; $5-1,5 \mu \mathrm{M}$ de EPZ015666 + $2 \mathrm{mM}$ de NOG; $6-1,5 \mu \mathrm{M}$ de EPZ015666+ 4 mM de NOG; 7 - Meio MEM com 1,2\% de DMSO (duplicata); 8 - somente meio MEM (duplicata), incubadas por 48 hs e coradas com cristal violeta $0,1 \%$.

Figura 39 - Teste de toxicidade do duplo inibidor em HEK293T.

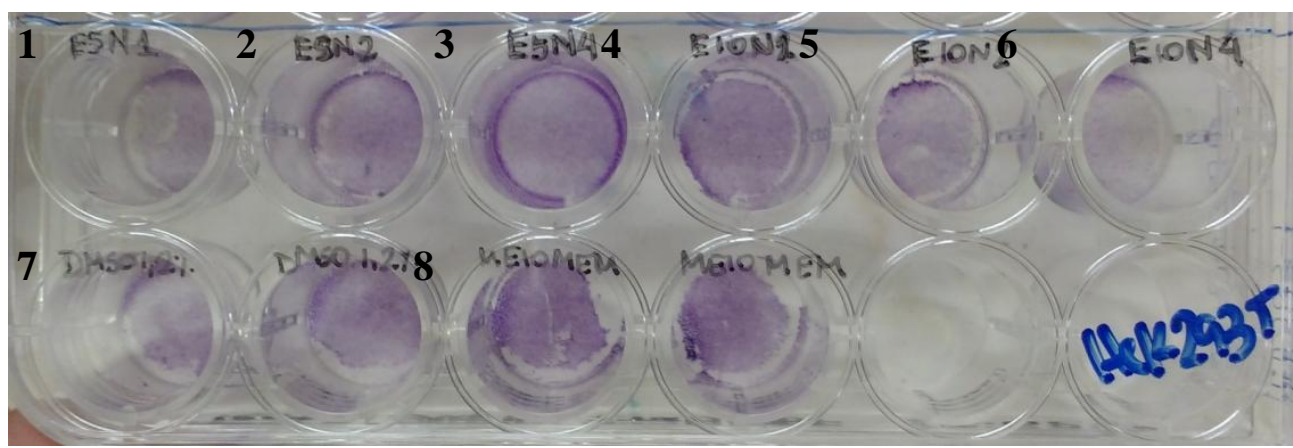

Células HEK293 foram incubadas com: 1 - $5 \mu \mathrm{M}$ de EPZ015666 + $1 \mathrm{mM}$ de NOG; 2 - $5 \mu \mathrm{M}$ de EPZ015666 + $2 \mathrm{mM}$ de NOG; $3-5 \mu \mathrm{M}$ de EPZ015666 + $4 \mathrm{mM}$ de NOG; $4-10 \mu \mathrm{M}$ de EPZ015666 + $1 \mathrm{mM}$ de NOG; $5-10 \mu \mathrm{M}$ de EPZ015666 + $2 \mathrm{mM}$ de NOG; $6-10 \mu \mathrm{M}$ de EPZ015666+ $4 \mathrm{mM}$ de NOG; 7 - Meio MEM com 1,2 \% de DMSO (duplicata); 8 - somente meio MEM (duplicata), incubadas por 48 hs e coradas com cristal violeta $0,1 \%$.

Para o experimento, células Hep-2 e HEK293T foram incubadas com as respectivas concentrações de inibidores por $24 \mathrm{hs}$, infectadas, $2 \mathrm{hs}$ depois da infecção o meio trocado para meio MEM 2\% de SFB com inibidores novamente e 48 hs pós infecção as células foram coletadas. Monitoramos a multiplicação do vírus pelos níveis de expressão de N. O resultado apresentado na figura 40 indica que não houve inibição da replicação viral. 
Figura 40 - Efeito da dupla inibição de metilação em arginina na replicação viral.

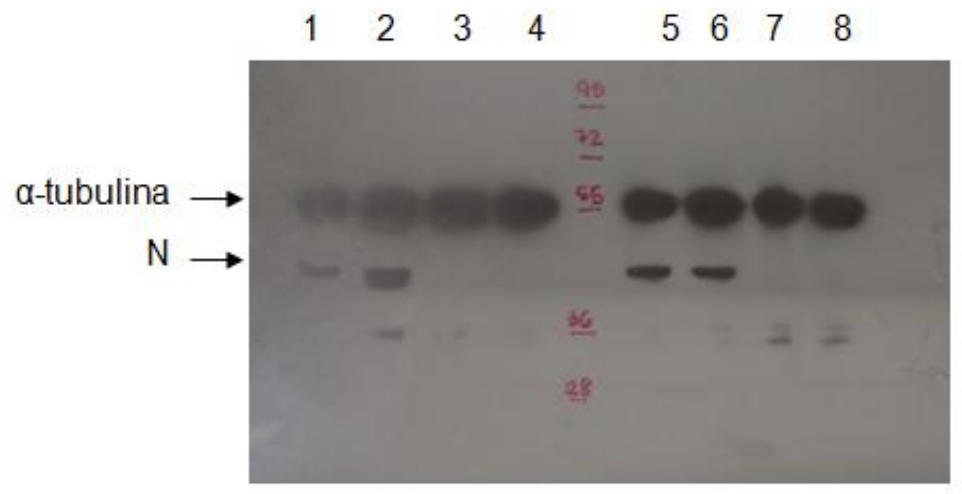

\begin{abstract}
Tratamento com inibidores 24hs, infecção 2hs, inibidores por mais 48 hs. Células Hep-2 (1-4) e HEK293T (5-8). O Western blotting do gel de SDS-PAGE 10\% foi incubado com anti- $\alpha$ tubulina (Abcam ${ }^{\circledR}$, Cambridge, Reino Unido) e anti-N (Abcam ${ }^{\circledR}$, Cambridge, Reino Unido) e secundário anti-camundongo (Abcam ${ }^{\circledR}$, Cambridge, Reino Unido). $1-3 \mu \mathrm{M}$ de EPZ015666 + 2 $\mathrm{mM}$ de NOG + HRSV; 2 - Meio MEM com 1,2 \% de DMSO + HRSV; 3 - $3 \mu \mathrm{M}$ de EPZ015666 $+2 \mathrm{mM}$ de NOG; 4 - Meio MEM com 1,2 \% de DMSO; $5-10 \mu \mathrm{M}$ de EPZ015666 $+2 \mathrm{mM}$ de NOG + HRSV; 6 - Meio MEM com 1,2 \% de DMSO + HRSV; 7 - $10 \mu \mathrm{M}$ de EPZ015666 + 2 mM de NOG; 8 - Meio MEM com 1,2 \% de DMSO.
\end{abstract}

\title{
4.8.4 Inibidores de metilação em lisina
}

Após verificar que a proteína $\mathrm{N}$ também apresentava resíduos de lisina metilados (itens 4.7.1 e 4.7.2), inibidores de metilação em lisina foram adquiridos: UNC0631, UNC0638, UNC0646 e EPZ004777 (ver item 3.13). Baseado em Hsiao et al (2015), que obteve inibição de H3K9me2 com $20 \mu \mathrm{M}$ de UNC0631, as concentrações escolhidas para o teste de toxicidade foram $10 \mu \mathrm{M}, 20 \mu \mathrm{M}$ e $40 \mu \mathrm{M}$. Lehnertz et al (2014) inibiu a produção de G9a com $1 \mu \mathrm{M}$ da UNC0638, por isso as concentrações escolhidas para o teste foram $0,5 \mu \mathrm{M}$, $1 \mu \mathrm{M}$ e $2 \mu \mathrm{M}$. Hsiao et al (2015) obteve a inibição de H3K9me2 com $10 \mu \mathrm{M}$ de UNC0646 e por isso as concentrações escolhidas foram $5 \mu \mathrm{M}, 10 \mu \mathrm{M}$ e $20 \mu \mathrm{M}$. Finalmente, para EPZ004777, Daigle et al (2011) inibiu H3K79me com $3 \mu \mathrm{M}$ da droga e assim, as concentrações escolhidas foram $1,5 \mu \mathrm{M}, 3 \mu \mathrm{M}$ e $6 \mu \mathrm{M}$.

Células Hep-2 e HEK293T foram incubadas com as drogas por 72 hs e em seguida coradas com cristal violeta. A figura 41 mostra o resultado do teste de toxicidade para os quatro inibidores. Como é possível observar, UNC0631 foi extremamente tóxico em todas as concentrações, enquanto que UNC0646 não foi tóxico em $5 \mu \mathrm{M}$ e $10 \mu \mathrm{M}$, já com $20 \mu \mathrm{M}$ foi possível observar uma pequena toxicidade. Tanto UNC0638 e EPZ004777 não foram tóxicos em nenhuma concentração. 
Figura 41 - Teste de toxicicidade dos inibidores de metilação em lisina em Hep-2 e HEK293T.

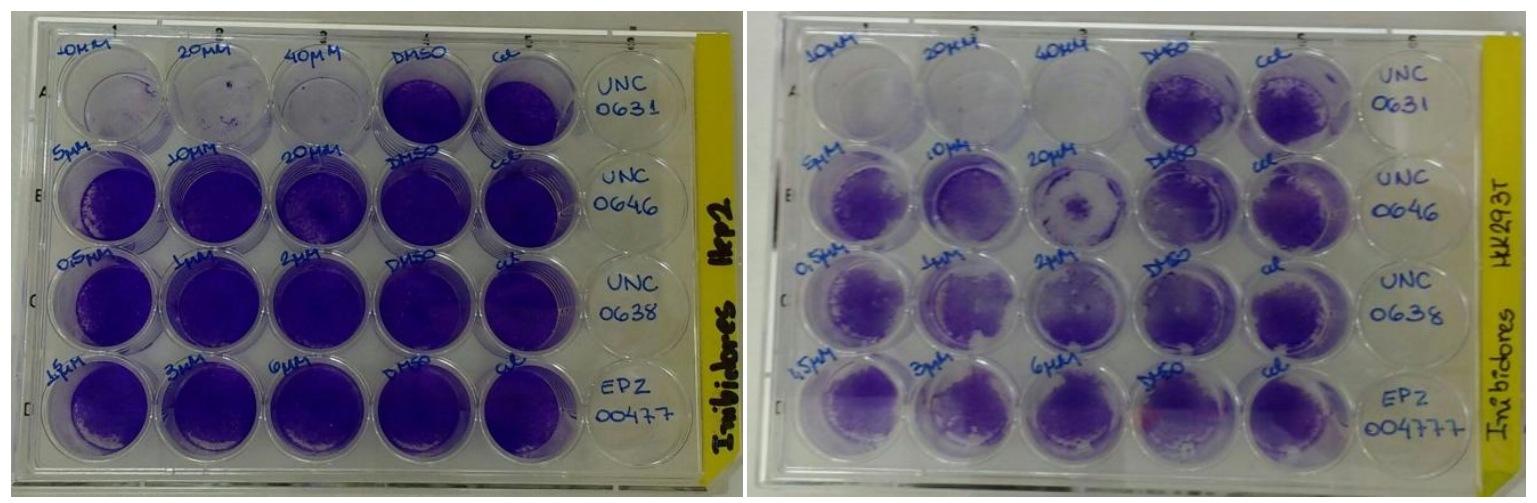

Célula Hep-2 e HEK293T foram incubadas com diferentes concentrações dos inibidores por 72 hs: $10 \mu \mathrm{M}, 20 \mu \mathrm{M}$ e $40 \mu \mathrm{M}$ de UNC0631; $5 \mu \mathrm{m}, 10 \mu \mathrm{m}$ e $20 \mu \mathrm{M}$ de $40 \mu \mathrm{M}$ de UNC0646; 0,5 $\mu \mathrm{M}, 1 \mu \mathrm{M}$ e $2 \mu \mathrm{M}$ de UNC0638; $1,5 \mu \mathrm{M}, 3 \mu \mathrm{M}$ e $6 \mu \mathrm{M}$ de EPZ004777; $1 \%$ de DMSO para todos os inibidores e meio $1 \%$ SFB sem inibidor como controle negativo. Após incubação por $72 \mathrm{hs}$ foram coradas com cristal violeta $0,1 \%$.

Em seguida foram feitos experimentos para verificar o efeito do inibidor na replicação viral. Para tal, células Hep-2 foram incubadas com os inibidores UNC0638, UNC0646 e EPZ004777 nas concentrações $2 \mu \mathrm{M}, 10 \mu \mathrm{M}$ e $6 \mu \mathrm{M}$, respectivamente, por 24 hs. Então as células foram infectadas e 48 hs após a infecção, coletadas. Como UNC0631 foi extremamente tóxico para as células, este não foi utilizado nos experimentos. A figura 42 mostra o resultado do western blotting do experimento e indica que não houve inibição da replicação viral em western blot monitorado com anti-P.

Após o resultado negativo, o mesmo experimento foi feito, mas desta vez as células foram mantidas com os inibidores durante o período de infecção. Células Hep-2 foram incubadas com os inibidores, 24 hs depois infectadas com meio com os inibidores e coletadas 48 horas pós infecção, ou seja, as células se mantiveram com os inibidores por 72 hs contínuas. Além disso, as concentrações dos inibidores foram dobradas. Para o UNC0638 foi utilizado $4 \mu \mathrm{M}, 20 \mu \mathrm{M}$ para UNC0646 e $12 \mu \mathrm{M}$ para o EPZ004777. A figura 43 mostra que mesmo com o aumento na concentração e continuidade na incubação com os inibidores a replicação do vírus foi afetada apenas suavemente com o UNC0646 (figura 43 canaleta 3). 
Figura 42 - Efeito dos inibidores de metilação em lisina na proteína P.

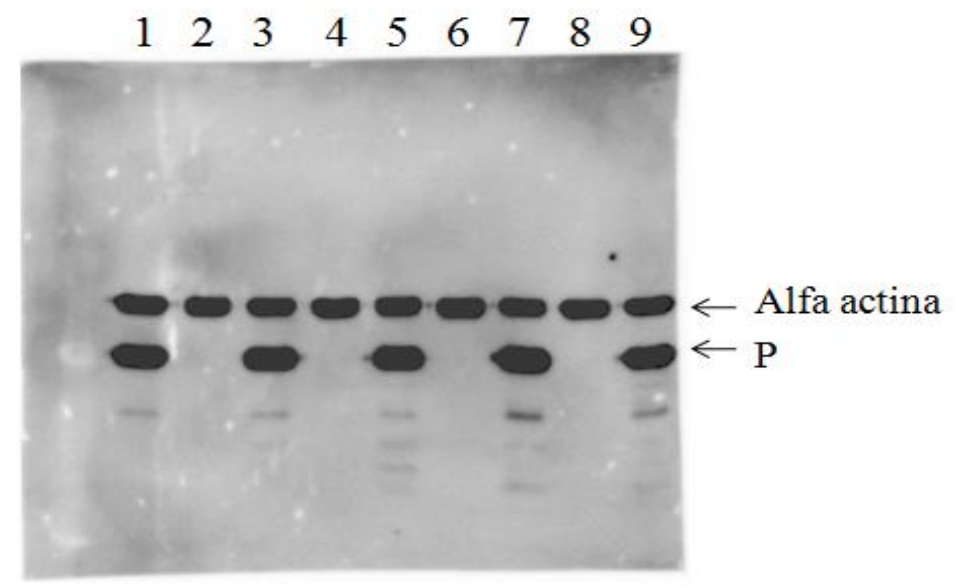

Célula Hep-2 incubada com inibidores e 24 hs depois, infectada. 1 - $10 \mu \mathrm{M} \mathrm{UNC0646}+\mathrm{HRSV}$; $2-10 \mu \mathrm{M}$ UNC0646; 3 - $2 \mu \mathrm{M}$ UNC0638 + HRSV; 4 - $2 \mu \mathrm{M}$ UNC0638; 5 - $6 \mu \mathrm{M}$ EPZ004777 + HRSV; 6 - $6 \mu$ M EPZ004777; 7 - MEM $1 \%$ DMSO + HRSV; 8 - MEM $1 \%$ DMSO; 9 MEM + HRSV.

Figura 43 - Efeito dos inibidores de metilação em lisina na expressão da proteína P.

$$
\begin{array}{lllllllll}
1 & 2 & 3 & 4 & 5 & 6 & 7 & 8 & 9
\end{array}
$$

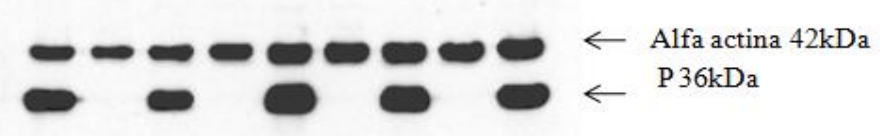

Está apresentada um western blotting do extrato celular de Hep-2 tratada com inibidores de metilação em lisina, incubadas por 72 hs e infectadas 24 hs após o começo do tratamento com os inibidores. 1 - $4 \mu \mathrm{M}$ UNC0638 + HRSV UNC0638 + HRSV; $2-4 \mu \mathrm{M}$ UNC0638; $3-20 \mu \mathrm{M}$ UNC0646 + HRSV; $4-20 \mu \mathrm{M}$ UNC0646; $5-12 \mu \mathrm{M}$ EPZ004777 + HRSV; $6-12 \mu \mathrm{M}$ EPZ004777; 7 - MEM 1 \% DMSO + HRSV; 8 - MEM $1 \%$ DMSO; 9 - MEM + HRSV.

Mesmo com o resultado pouco significativo com a proteína $\mathrm{P}$, outro western blotting com as mesmas amostras do experimento da figura 43 foi feito, porém revelado com anticorpos contra outras proteínas do vírus. A figura 44 mostra que tanto a proteína $\mathrm{N}$ e com a proteína $\mathrm{G}$ foram inibidas em células tratadas com o inibidor UNC0646. Análise com o 
programa Image J indica que a intensidade da banda diminuiu em $86,19 \%$ para a proteína G e em 73,27 \% para proteína N. Esses dados indicam que a interação N-metilossomo tem potencial para ser explorada como alvo terapêutico no desenvolvimento de antivirais contra HRSV.

Figura 44 - Efeito dos inibidores de metilação em lisina na expressão das proteínas G e N.

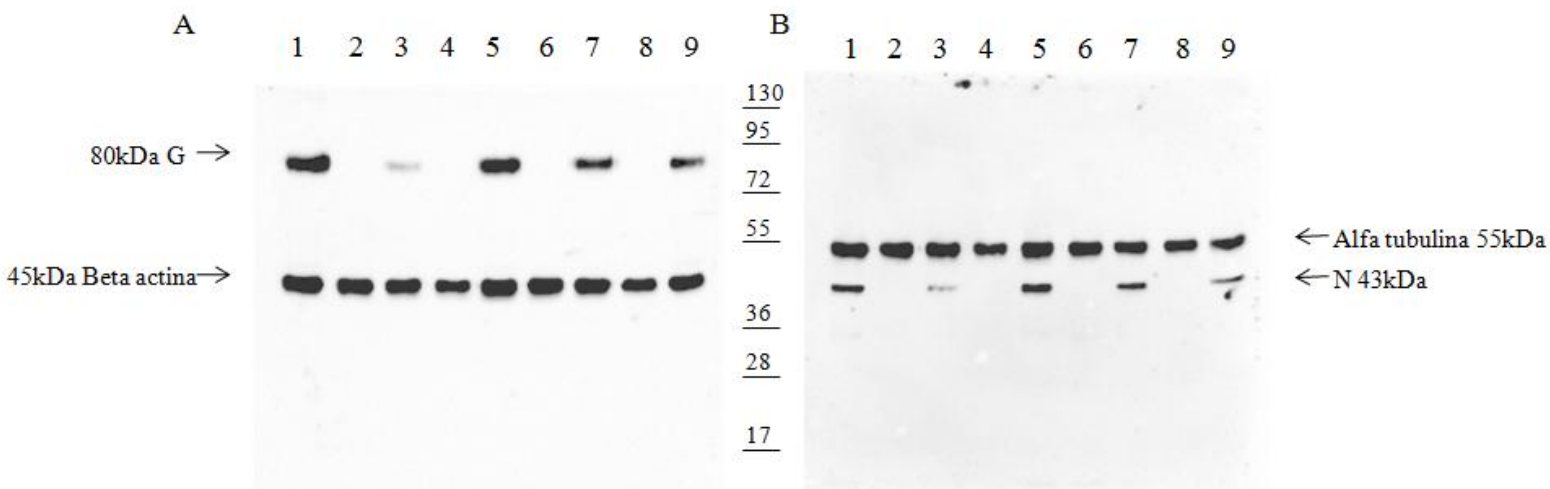

Está apresentada um western blotting do extrato celular de Hep-2 tratada com inibidores de metilação em lisina, incubadas por 72 hs e infectadas 24 hs após o começo do tratamento com os

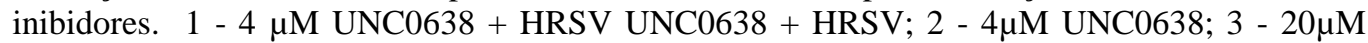

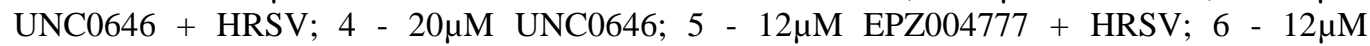
EPZ004777; 7 - MEM 1\% DMSO + HRSV; 8 - MEM 1\% DMSO; 9 - MEM + HRSV. Membrana revelada com: A - anti-G e Anti- $\beta$ actina; B - Anti-N e anti- $\alpha$ tubulina. 


\section{DISCUSSÃO}

Neste trabalho abordamos uma das interações entre proteínas do HRSV com proteínas da célula hospedeira, identificada em trabalho anterior do laboratório (Oliveira et al 2013), a interação entre a proteína $\mathrm{N}$ e as proteínas do metilossomo. Primeiro confirmamos a interação na linhagem celular Hep2 (no trabalho original foram utilizadas células HEK293T), utilizando um anticorpo monoclonal contra $\mathrm{N}$ comercialmente disponível (figura 6). Partimos então para confirmar a interação com outras abordagens e a busca de evidências da importância funcional do evento de metilação promovido pelo metilossomo, e justificar porque o vírus estaria recrutando essa atividade.

O evento de metilação em argininas e/ou lisinas tem o potencial de interferir na dinâmica da interação N-RNA, tanto pela modificação das proteínas virais envolvidas, quanto de proteínas celulares associadas ainda não identificadas. Essas modificações podem ter a função de modular a atividade do complexo RNA polimerase RNA dependente, constituído pelas proteínas virais L e P, na transcrição dos mRNAs, anti-genoma e genoma virais.

\subsection{Interação $N$-WDR77/PRMT5 com proteínas expressas em bactérias}

A primeira abordagem que utilizamos para reforçar o dado de interação foi testar se o metilossomo estaria interagindo com $\mathrm{N}$ através da proteína WDR77, que é o componente do complexo metilossomo que tem a função de reconhecer os substratos a serem metilados (ANTONYSAMY et al. 2012). Como observamos essa interação em células humanas no trabalho de Oliveira et al (2013) e figura 6, utilizamos os genes N e WDR77 otimizados para expressão em bactérias clonados nos vetores pET e pGEX respectivamente (ver item 3.2). Esses plasmídeos foram utilizados para co-transformar bactérias e analisar se no pull down de GST-WDR77 a proteína His-N viria associada. Essa estratégia foi utilizada anteriormente com sucesso para caracterizar a interação N-P (CASTAGNE et al. 2004). O dado da figura 7 , mostra que isso não foi possível pelo fato dessas proteínas terem sido expressas na forma majoritariamente insolúvel.

Tentamos então obter o metilossomo solúvel em bactérias através da co-expressão de WDR77 e PRMT5, repetindo a estratégia de Castagne et al. (2004), para testar se o complexo inteiro interage com $\mathrm{N}$ in vitro. $\mathrm{O}$ resultado apresentado à figura 8 mostra que o par pGEXPRMT5 + pET-WDR77 gerou expressão solúvel, e o dado à figura 9 mostra a detecção da 
formação de um complexo de aproximadamente $450 \mathrm{KDa}$, obtido por pull down de GSTPRMT5 e compatível com o octâmero do metilossomo. A presença dessas proteínas foi confirmada nesse complexo através de western blot (figura 10).

Com essa ferramenta tornou-se possível testar a interação $\mathrm{N}$-metilossomo in vitro fazendo uma modificação na estratégia de co-expressão, obtendo o metilossomo em uma bactéria e $\mathrm{N}$ em outra. Bactérias com o metilossomo e com a proteína $\mathrm{N}$ foram sonicadas juntas. Bactérias que expressaram a $\mathrm{N}$ foram também sonicadas sozinhas para o controle negativo. No pull down com GS-beads, foi possível verificar que o metilossomo expresso em bactérias trouxe junto a proteína His-N (Figuras 11, 12 e 13). Esse dado reforça o achado de interação N-metilossomo.

\subsection{Co-localização intracelular entre $N$ e metilossomo}

Utilizando um sistema que mimetiza o processo de expressão dos genes virais, em que vetores de expressão para os genes N, M2-1, P ou L do HRSV, clonados sob o comando do promotor T7 são expressos no citoplasma de células BSRT7/5, como descrito em Fix, (2011); Tran, (2009), buscamos evidenciar a co-localização de $\mathrm{N}$ e metilossomo (item 3.6). Isso foi feito pela utilização de anticorpos específicos para $\mathrm{N}$ que detecta estruturas características da replicação, os corpúsculos de inclusão viral, concomitantemente com anticorpos anti PRMT5 (CARROMEU et al., 2007, SIMABUCO et al., 2009). O resultado de imunofluorescência apresentado à figura 14 mostra que ocorre a co-localização da proteína celular PRMT5 com a viral $\mathrm{N}$ nos corpúsculos de inclusão. Como as células BSRT7/5 são derivadas de células BHK-21, fibroblastos de hamster, temos indicação de interação em sistema heterologo (células não humanas).

Fizemos então tentativas de demonstrar essa co-localização em células humanas (Hep2) infectadas também através de imunofluorescência, no entanto a expressão de PRMT5 mostrou-se insuficiente para caracterizar o fenômeno (item 4.4, dados não apresentados). Optamos por aumentar a expressão transfectando vetores contendo os cDNAs de PRMT5 e WDR77 adquiridos da empresa Origene, no entanto esses genes tiveram que ser sub-clonados pois não expressaram bem (dados não apresentados). Essa sub clonagem foi feita em vetor pcDNA3 (Dr. Fernando Simabuco, dados não publicados, item 3.2).

O resultado de imunofluorescência apresentado à figura 15 , indica que nas células transfectadas com pcDNA-HA-PMRT5, o nível de expressão é elevado e ocorre uma co- 
localização com N derivado da infecção. Já a transfecção de pcDNA-HA-WDR77 gerou um padrão de expressão mais nuclear Figura 16), no entanto é notável que pode ser observado em várias células uma concentração de marcação coincidente com a marcação de $\mathrm{N}$ nos corpúsculos de inclusão (merge da figura 16). A dupla transfecção (pcDNA-HA-PMRT5 e pcDNA-HA-WDR77) gerou um padrão de co-localização do metilossomo com N proveniente da infecção mais evidente (figura 17). Neste caso é importante ressaltar que utilizamos células HEK293T devido à maior eficiência de transfecção nelas obtida.

Com células Hep2 infectadas buscamos visualizar essa co-localização utilizando microscopia confocal. Às figuras 18, 19 e 20 podemos observar nas células transfectadas com pcDNA-HA-PMRT5, pcDNA-HA-WDR77 ou com os dois plasmídeos, respectivamente, corpúsculos de inclusão com sobreposição de marcação apontados pelas setas.

Esse conjunto de dados, também reforça a hipótese de interação de $\mathrm{N}$ com o metilossomo.

\subsection{Inibição da PRMT5 por si RNA e seu efeito na replicação viral}

Fizemos então experimentos para verificar se há um papel do metilossomo na replicação viral. Para tanto, investimos na inibição da PRMT5 com siRNA por transfecção em células HEK293T, seguida de infecção, e uma segunda transfecção de siRNA (item 4.5). O nível de inibição de PRMT5 que conseguimos obter foi apenas em torno de 50\% (Figura 21, canaletas 1 e 2 x o controle na 3). Nessa condição tentamos evidenciar efeito sobre o HRSV, mas pelo resultado apresentado na figura 22, não foi possível inibir o vírus com esta estratégia. Tentamos utilizar outro siRNA descrito em Bandyopadhyay et al. (2012) e também não obtivemos efeito (experimentos não apresentados).

Abandonamos essa estratégia devido, mas é possível que utilizando formas mais eficientes de inibição de PRMT5, a visualização de algum efeito seja possível, como indicam dados anteriores da literatura para HIV. A ativação de PRMT1 e PRMT5 juntas reprimem a transcrição a partir do LTR de HIV e consequentemente a replicação do vírus (KWAK et al., 2003). PRMT6 inibe a transcrição do HIV-1 através da metilação do Tat, Ver e proteínas do nucleocapsídeo (BOULANGER et al., 2005; INVERNIZZI et al., 2006; SINGHROY et al., 2013; XIE et al., 2007). Como pode-se notar, mais de uma PRMT pode metilar proteínas do mesmo vírus, os integrantes das famílias arginina metiltransferase podem se sobrepor e compensar a perda de função de outro integrante (ZHANG; HUSSAIN; ASGARI, 2014). Esta 
seria mais uma explicação para não termos observado a inibição da replicação do HRSV utilizando siRNA contra PRMT5.

\subsection{Aumento da expressão do metilossomo e seu efeito na replicação viral}

O objetivo do aumento da expressão, ou superexpressão PRMT5 e/ou da WDR77 por tranfecção, seria de fazer um contraponto à inibição de PRMT5. O experimento de foi feito pela transfecção seguida de infecção (ver item 4.6), utilizando os plasmídeos pcDNA-HAPRMT5 e pcDNA-HA-WDR77, comentados anteriormente (item 5.2). O resultado indica que a transfecção da PRMT5 resultou em aumento expressivo de proteína, o que não foi evidenciado para WDR77 (figura 23A). A replicação viral monitorada pela expressão de N, no entanto, não foi afetada significativamente pela tanto pela transfecção individual quanto conjunta dos vetores (figura 23B). O resultado apresentado foi em células Hep2, sendo que dado similar foi obtido em células HEK293 (não apresentado).

É importante ressalvar que as células utilizadas no experimento, Hep-2 e HEK293T, são transformadas. Em células imortalizadas ou transformadas é reportado que o nível de expressão de PRMT5 é maior do que em culturas de células primárias (PANFIL et al., 2015). Assim, é possível que o adicional de expressão pela transfecção de PRMT5 nas células utilizadas em o nosso experimento não mude o contexto a ponto de produzir um efeito sobre o vírus.

\subsection{Metilação na proteína $N$}

Como temos evidências de que a proteína $\mathrm{N}$ interage com o metilossomo, buscamos então verificar se haveria metilação direta dessa proteína viral em resíduos de arginina pelo metilossomo (item 4.7). Numa abordagem inicial, do experimento apresentado à figura 6 , em que células Hep-2 foram infectadas e feita imunoprecipitação com anticorpo anti-N, o produto dessa imunoprecipitação foi submetido a um gel preparativo e a banda do gel (corado com Coomassie Blue), correspondente à N, foi analisada por espectrometria de massas no CEFAPICB-USP (ver item 3.11). O resultado indicou metilação em um resíduo de arginina mas com grau de confiança muito baixo (não apresentado). 
Resolvemos então analisar a proteína $\mathrm{N}$ em fusão com o peptídeo FLAG expressa em células HEK-293T pela transfecção do plasmídeo pFLAG-N (item 3.2), o que permite a imunoprecipitação através de anticorpos altamente eficientes contra o peptídeo FLAG, e leva a uma purificação parcial da proteína de fusão, como pode ser visto à figura 24. Além disso, foi com FLAG-N que a interação com o metilossomo havia sido originalmente detectada (Oliveira et al., 2013). Utilizando anticorpos contra metil e di-metil arginina (Abcam), desenvolvidos para detectar a clássica metilação em histonas, conseguimos evidenciar positividade para argininas mono e di-metiladas em FLAG-N (figura 25). O tipo I de PRMT forma argininas monometiladas e dimetiladas assimétricas, as do tipo III só produzem argininas monometiladas. Assim como as enzimas do tipo I e III, a PRMT do tipo II (PRMT5) cataliza a monometilação, mas uma segunda reação faz com que realize também dimetilações simétricas (Morales et al., 2016). Por isso nos resultados é coerente observar dois tipos de metilação diferentes em uma mesma amostra.

A proteína FLAG-N assim obtida foi submetida a gel preparativo (figura 26), e enviada para análise pela MSBioworks com o protocolo PTM-Profiling plus (ver item 3.11). O resultado dessa análise mostrou diversos resíduos metilados, estando apresentados na tabela 1 os com maior grau de confiabilidade: K42, K46, R150, K293 e K358. Este resultado foi uma surpresa já que em trabalhos anteriores do laboratório, que deram origem a este, não foi detectada nenhuma metiltransferase de lisina e a imunoprecipitação da proteína $\mathrm{N}$ mostrou interação somente com a metiltransferase de arginina.

Galloux et al., 2012 mostram que o sítio de ligação da proteína N com a P consiste em cadeias laterais hidrofóbicas dos resíduos M50, I53 e Y135, parte alifática do R150, aceptores de hidrogênio nos resíduos E128, S131, H151 e D152 e doadores de hidrogênio nos resíduos K46, S131, R132 e H151. Para determinar se o defeito na atividade polimerase estava associada com defeito na interação entre N e P, Galloux e cols. realizaram experimentos com $\mathrm{N}$ mutada em diversos resíduos e verificaram que mutações no K46, R132 e R150, independentemente, resultam na perda da interação entre as proteínas virais $\mathrm{N}$ e P. Temos assim, que ao menos as metilações em K46 e R150 que encontramos têm suporte de funcionalidade nesses dados.

Os resíduos metilados identificados podem ser localizados na estrutura da proteína $\mathrm{N}$ resolvida por cristalografia de raios-X (Tawar et al., 2009). À figura 27 está em destaque o sítio de ligação de P. os resíduos de arginina e lisinas metilados, R150, K42 e K48 (Tabela 1) estão em posições interessantes, pois estão localizados adjacentes ou no sítio de ligação com a 
proteína $\mathrm{P}$, como mostra a figura 27. Além dos resíduos localizados próximos ao local de interação com a proteína P, as lisinas K293 e K358 (Tabela 1) estão localizadas próximo ao domínio de N que faz interação com o RNA viral (figura 28).

Como esses dados foram obtidos analisando a proteína FLAG-N, expressa por transfecção, é importante verificar o que ocorre na proteína N proveniente do vírus. Para obter massa suficiente para análise, grande quantidade de células Hep-2 foi infectada com HRSV e as amostras imunoprecipitadas com anti-N monoclonal (Abcam®, Cambridge, Reino Unido). A banda correspondente a $\mathrm{N}$ foi cortada de gel preparativo e enviada para análise por espectrometria de massas pela MSBioworks, Michigan, EUA, com o protocolo PTMProfiling plus (ver item 3.11). Os resultados obtidos, indicando as posições com maior grau de confiabilidade, estão na tabela 2. Os resíduos onde foram encontradas metilações estão indicados na figura 29.

Foi confirmado que a proteína $\mathrm{N}$ proveniente da replicação viral, como FLAG-N, diversos resíduos de lisinas e agora dois de arginina têm indicação de metilação e estão próximos ao sítio de interação com a $\mathrm{P}$ e ao local de interação com o RNA. As lisinas nas posições 42, 46 e 358 apareceram também na análise da FLAG-N, sendo que 42 e 358 obtiveram ascore máximo nas duas análises. É importante notar que a arginina 150 também se manteve com ascore máximo, confirmando a correlação de importância funcional frente aos dados de mutagênese obtidos por Galloux et al, 2012.

Da mesma forma que para visualizar metilação em arginina, foi adquirido um anticorpo anti-lisina metilada. No resultado à figura 30 observa-se uma banda fraca na altura da proteína $\mathrm{N}$ tanto na amostra de vírus ultracentrifugado quanto de extrato de células infectadas. Podemos especular sobre esse padrão (similar ao que observamos com os anticorpos anti-metil arginina), que podemos estar diante de um processo dinâmico de metilação/demetilação tendo como consequência a modificação não estar presente em todas as moléculas de $\mathrm{N}$.

De forma surpreendente, observa-se bandas fortes tanto na amostra do vírus ultracentrifugado quanto no extrato de células infectadas, na altura correspondente à proteína P. Postulamos que isso indica a presença de outras proteínas com metilação em lisina aumentada, sejam do vírus ou da célula, no contexto da infecção viral. A presença dessas bandas em extratos de outras células infectadas foi confirmada (dado não apresentado), nos apresentando um novo fenômeno a ser explorado. Assim, esse anticorpo foi testado em células infectadas e não infectadas por imunofluorescência em células Hep-2. Como pode ser 
observado na figura 31, o padrão de marcação com anti-metil lisina é distinto em células infectadas havendo um aumento significativo de pontos de concentração da marcação. Ao sobrepor as marcações de anti-N e anti-metil lisina, há uma indicação de co-localização do corpúsculo de inclusão com os locais de concentração de lisina metilada em boa parte das células infectadas (figura 32). Isso indica a potencial importância dessas modificações pós traducionais nas interações das proteínas virais envolvidas na replicação.

Isso também pode ser significativo em termos de estrutura, já que existem relatos de proteínas que, ao serem metiladas mudam de conformação, como por exemplo CAMR1 (cofator da PRMT1) que induz mudanças conformacionais no AdoHcy para gerar acesso ao sítio de metilação (BLEE, 2015; BEDFORD, 2009). Podemos especular que a metilação de lisinas levaria a mudança de conformação capaz de modular a ligação da proteína $\mathrm{N}$ ao RNA viral e assim a transcrição/replicação do genoma viral.

Sabe-se da importância dos mecanismos de controle pós transcricionais, que são mediados por inúmeras, muitas vezes multifuncionais, proteínas que se ligam ao RNA. Muitas proteínas que se ligam ao RNA possuem modificações pós-traducionais e essas modificações podem alterar o estado da sua estrutura/conformação e, portanto, regular sua função ao influenciar sua localização celular, atividade de ligação ao RNA e interação proteína-proteína. Por exemplo, a proteína do retardo mental do $\mathrm{X}$ frágil é uma proteína regulatória citoplasmática metilada, a ausência da qual é ligada à síndrome do $\mathrm{X}$ frágil. Ela se liga a cerca de $4 \%$ do mRNA fetal e possui papel no transporte, estabilidade, ativação traducional e repressão. Outro exemplo é a proteína embrionária letal da visão anormal (ELAV), que também se liga ao RNA e se encontra predominantemente no núcleo para regular o processamento do mRNA. Porém sabe-se que a ELAV migra até o citoplasma onde se liga aos elementos ricos em AU na porção 3'-UTR para estabilizar, desestabilizar, reprimir ou ativar o mRNA (BLEE; GRAY; BROOK, 2015). Por isso é coerente uma proteína que se liga ao RNA e se encontra no citoplasma da célula ser metilada para realizar suas funções regulatórias, como a $\mathrm{N}$.

Segundo Esse et al (2013), a maioria das proteínas alvo das metiltransferases são proteínas que se ligam ao RNA (RBP) e possuem o motivo GAR. A K293 está localizada espacialmente próxima ao sítio de ligação com o RNA e a uma região com resíduos RGG (figura 45), reforçando a hipótese de que sua metilação cause mudança conformacional afetando a interação de $\mathrm{N}$ com o RNA. 
Figura 45 - Potencial interferência da metilação na ligação de N ao RNA

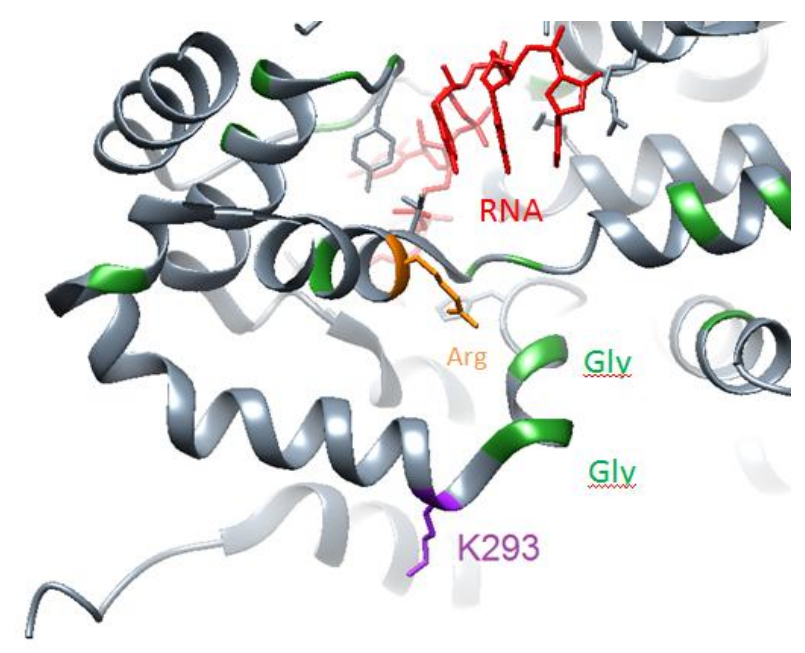

Está apresentada imagem de um detalhe da proteína N, obtida conforme a descrição na legenda da figura 27. Local da lisina metilada (K293 em roxo), próxima a uma arginina (em laranja) e glicinas (em verde), que também fica próximo ao RNA viral (vermelho).

A maioria das proteínas não histonas que são metiladas em lisinas são fatores de transcrição ou enzimas que modificam DNA ou histonas. Interessantemente, a maioria destas proteínas são metiladas pela KMT7, que possui forte atividade em histonas livres, mas fraca atividade em histonas nucleossomais, indicando que sua principal atividade é regular proteínas não histonas. Sabe-se que a proteína p53 é uma proteína citoplasmática que possui lisina metilada para regular sua atividade de interação com outras proteínas e sua estabilidade. O fator de associação TAF10 ao TATA-box (TBP) quando metilado aumenta sua afinidade pela RNA polimerase II, auxiliando na formação do complexo de pré-inicialização. Já a proteína do Retinoblastoma $(\mathrm{Rb})$, quando metilada na lisina 873 promove sua associação com a proteína HP1 para a repressão do gene e diferenciação. Quando metilada na lisina 810, a modificação impede que esta se ligue ao CDK e portanto previne a sua função. A metilação de lisina nas proteínas DNMT1, E2F1, STAT3 e NFkB regula negativamente sua estabilidade e sua função de transativação (ZHANG; WEN; SHI, 2012).

Burton e Consigli (1996) foram os primeiros a detectar metilação em lisina em proteínas virais. Desde então, muitos outros exemplos de metilação em lisina foram reportadas (LLANOUETTE et al., 2014). Dheekollu et al. (2016) mostrou que o fator 1 da célula hospedeira (HCF1), um complexo metiltransferase de histona, metila $\mathrm{H} 3 \mathrm{~K} 4$ da origem de replicação do plasmídeo (OriP) do vírus Epstein-Barr e junto com o fator de transcrição OCT2 e o EBNA1, regulam a transcrição viral, modificações em histonas e manutenção 
epissomal durante a infecção latente. Já para o Herpesvirus, durante a replicação, a metilação na H3K27 associada ao promotor do gene E reduz significativamente durante a replicação do DNA viral, ao passo que a metilação na H3K9 diminui quando a replicação viral é inibida (KRISTIE, 2016). Também sabe-se que a proteína Tat do HIV é metilada na lisina 50 pelo Set/9/KMT7 e a demetilaçao da lisina 51 pela LSD1/KDM1 e ativa a transativação da Tat (SAKANE et al., 2011). Por isso é coerente detectar proteínas virais com metilação em lisina, como a N, e deduzir que estas metilações podem estar ligadas a regulação da replicação viral.

\subsection{Inibidores de metilação e demetilação em arginina e seu efeito na replicação viral}

Está bem estabelecido que a PRMT5 é superexpressa em diversos tipos de câncer, como câncer de ovário, próstata, mama, pulmão, nasofaringe, melanoma e também em carcinomas causados por vírus como linfoma por HTLV-1 e linfoma por EBV (ALINARI et al., 2012; BAO et al., 2013; GU et al., 2012; NICHOLAS et al., 2013; PANFIL et al., 2016; SHARMA et al., 2014; YANG et al., 2015). Isso levou à tentativa de utilizar a inibição de PRMT5 como alvo para terapia do câncer, e ao consequente de desenvolvimento de inibidores dessa enzima.

Neste experimento testamos um inibidor de metilação para verificar o seu efeito na replicação viral (item 4.8.1). Depois de determinar as concentrações não tóxicas em células Hep-2 e HEK293T (figuras 33 e 34), estas foram incubadas com diferentes concentrações dos inibidores, separados ou juntos, infectados e incubados novamente. O resultado apresentado na figura 35 mostra que não houve efeito na replicação viral. DHAR et al. (2013) mostraram que ao inibir totalmente a atividade da PRMT1, há um aumento global dos níveis de monometil arginina e dimetil arginina simétrica. Isto se deve ao fato da PRMT1 ser responsável por $90 \%$ da dimetilação assimétrica de arginina. Com a perda da PRMT1 os substratos ficam disponíveis para as metilargininas do tipo II e III. Segundo Dhar et al. (2013), sabe-se que o mesmo resíduo de arginina pode ser metilado tanto por PRMTs do tipo I quanto do tipo II, como por exemplo a arginina R698 do sítio de ligação da polimerase II do fator de elongação SPT5 que pode ser metilado tanto pela PRMT1 (tipo I), quanto pela PRMT5 (tipo II) (BEDFORD; RICHARD, 2005). Assim, o mesmo pode ter acontecido em nossos experimentos. Como o inibidor de metilação que utilizamos é específico para a PRMT5, o substrato ficaria disponível para outras metiltransferases, não afetando a replicação 
viral. PRMT 1 é uma boa candidata para esta substituição por fazer a maior proporção da metilação assimétrica e metilar 90\% das argininas (HU et al., 2016).

Em dado relativamente recente, Liu et al. (2013) demonstraram que a PRMT5 interage com a demetilase JMJD6. Testamos então o efeito do inibidor de JMJD6, NOG na replicação do HRSV. A toxicidade dessa droga foi testada (figura 36), e o impacto sobre a replicação viral avaliado (figura 37), indicando que não há efeito (item 4.8.2).

No entanto, tentamos ver, se apesar da não detecção de efeito dos inibidores de metilação e demetilação de arginina, a somatória de seus efeitos poderia influenciar a replicação viral. Após testar a citotoxicidade dessas drogas em conjunto (figuras 38 e 39), o resultado apresentado na figura 40 mostra que não houve efeito na replicação viral.

Esta é uma questão que precisa ser melhor avaliada, eventualmente quando houver a disponibilidade de novos inibidores.

\subsection{Inibidores de metilação em lisina e seu efeito na replicação viral}

Como o resultado de metilação em lisina foi inesperado, não tivemos tempo ainda para fazer uma análise aprofundada da metilação e da metiltransferase responsável por esta metilação. Por isso, os inibidores foram escolhidos baseados no artigo de He et al. (2012). UNC0631, UNC0638 e o UNC0646 são inibidores da metiltransferase G9a, enquanto que EPZ004777 é inibidor da DOT1 (HE et al., 2012). A metiltransferase G9a pertence a família de metiltransferases que metila a p53, uma proteína citoplasmática, por isso estes inibidores foram escolhidos, além de se mostrarem altamente eficientes. Já DOT1 é responsável por metilar H3K79 e está associada com a elongação na transcrição, como descrito no trabalho de He et al. (2012) e foi escolhida por metilar proteínas no núcleo, assim cobrimos metiltransferases que atuam em lisinas de proteínas citoplasmáticas e nucleares.

O grupo de metiltransferases de lisina é extenso. São divididas em oito famílias: KMT1, KMT2, KMT3, KMT4, KMT5, KMT6, KMT7 e KMT8, com 1 a 8 metiltransferases em cada (ZHANG; WEN; SHI, 2012). Assim, apesar de tentar abranger inibidores que atuam com metiltransferases nuclear e citoplasmática, não necessariamente os inibidores escolhidos têm efeito na metiltransferase que metila as proteínas do HRSV ou celulares alvo de durante sua replicação.

Assim, depois de comprovada a existência de metilação em lisina, foram feitos experimentos com quatro inibidores (item 4.8.3). Foi analisada a toxicidade dos mesmos onde 
células Hep-2 e KEK293T (figura 41). O inibidor UNC0631 foi extremamente tóxico e não foi possível utilizá-lo. Em experimento com as concentrações máximas, não tóxicas, o resultado mostrou que não houve diferença na expressão da proteína $\mathrm{P}$, usada para monitorar a replicação, se comparado com o controle (figura 42). Como no protocolo utilizado interrompemos a incubação com os inibidores durante o processo de infecção, resolvemos fazer novo experimento mantendo os inibidores de forma contínua. $\mathrm{O}$ resultado apresentado à figura 43 mostra um pequeno efeito inibitório de UNC0646, o que nos levou a refletir sobre uma possível falha no monitoramento da replicação viral utilizando a expressão de P.

Em dado recente, De Jesus (2016) mostrou que o modelo conhecido da família Paramixoviridae de transcrição em gradiente decrescente sequencial não é válido para o HRSV, ou seja, não observaram um gradiente decrescente de transcritos em direção à extremidade 5' do genoma. de Jesus observou que a proteína $\mathrm{P}$ teve altos níveis de transcritos durante toda a infecção. Isso pode ser justificado porque a proteína $\mathrm{P}$ possui diversos papéis dentro da célula infectada, como fazer parte do complexo de replicação dentro dos corpúsculos de inclusão e também interferir na via extrínseca da apoptose. Devido a todas as funções da P dentro da célula, é razoável encontrar grandes quantidades na célula infectada e não conseguir observar grandes variações na sua expressão em células tratadas com os inibidores.

Em seu trabalho, De Jesus (2016) também mostrou que a proteína N esteve bastante expressa durante a infecção, mas os níveis de mRNA encontrados ainda foram menores do que a proteína $P$. Já a proteína $G$ foi uma das menos expressas juntamente com a M e a L durante as 48 hs de infecção. Assim, é mais coerente monitorar o efeito da inibição viral com anticorpos anti-G e anti-N, o que foi feito para as mesmas amostras no experimento apresentado à figura 44. De forma coerente, pudemos então documentar um significante efeito inibitório pelo inibidor UNC0646 (canaletas 3A e 3B). Análise com o programa ImageJ indica que a intensidade da banda diminuiu em $86,19 \%$ para a proteína $\mathrm{G}$ e em $73,27 \%$ para proteína $\mathrm{N}$.

Esses dados indicam que a interação N-metilossomo tem potencial para ser explorada como alvo terapêutico no desenvolvimento de antivirais contra HRSV. 


\section{CONCLUSÕES}

Em estudo de interação entre a N e PRMT5/WDR77 expressas em bactéria seguido de pull down, foi observado que há interação entre a proteína viral e as proteínas do metilossomo.

Em estudos de co-localização por imunofluorescência entre N e PRMT5/WDR77, sendo $\mathrm{N}$ expressa pelo sistema mini genoma ou por infecção foi possível observar a colocalização dessas proteínas.

Em estudos de inibição da PRMT5 por siRNA foi observado que não houve efeito sobre a replicação viral.

Em estudo da superexpressão da PRMT5 e/ou WDR77 foi observado que não houve efeito sobre a replicação viral.

Em estudo da proteína $\mathrm{N}$ em células infectadas ou transfectadas por espectrometria de massas, foi observado nos dois casos, que há metilação em argininas e lisinas.

Em estudo de inibição da metilação ou demetilação de arginina por inibidores foi observado que não houve efeito sobre a replicação viral.

Em estudo de inibição da metilação de lisina, foi observado que houve inibição significativa da replicação viral por um de três inibidores testados. 


\section{REFERÊNCIAS*}

ALINARI, L. et al. Selective inhibition of protein arginine methyltransferase 5 blocks initiation and maintenance of B-cell transformation. Blood, v. 125, p. 2530-2543, 2015.

AL-QAHTANI, K. et al. The broad spectrum 2-oxoglutarate oxygenase inhibitor $\mathrm{N}$ oxalylglycine is present in rhubarb and spinach leaves. Phytochemistry, v. 117, p. 456-461, 2015.

ANTONYSAMY, S. Crystal structure of the human PRMT5: MEP50 complex. Proceedings of the National Academy of Science of United States of America, v. 109, p. 17960-17965, 2012.

AZEVEDO, C.; SAIARDI, A. Why always lysine? The ongoing tale of one of the most modified amino acids. Advances in Biological Regulation, v. 60, p. 144-150, 2015.

BAKKER, S. E. et al. The respiratory syncytial virus nucleoprotein-RNA complex forms a left-handed helical nucleocapsid. Journal of General Virology, v. 94, p. 1734-1738, 2013.

BANDYOPADHYAY, S. et al. HOXA9 Methylation by PRMT5 Is Essential for Endothelial Cell Expression of Leukocyte Adhesion Molecules. Molecular and Cellular Biology, v. 32, p. 1202-1213, 2012.

BAO, X. et al. Overexpression of PRMT5 Promotes Tumor Cell Growth and Is Associated with Poor Disease Prognosis in Epithelial Ovarian Cancer. Journal of Histochemistry \& Cytochemistry, v. 61, p 206-217, 2013.

BEDFORD, M. T.; CLARKE, S. G. Protein Arginine Methylation in Mammals: Who, What, and Why. Molecular Cell, v. 33, p. 1-13, 2009.

BEDFORD, M. T.; RICHARD, S. Arginine methylation: An emerging regulator of protein function. Molecular Cell, v. 18, p. 263-272, 2005.

BENEDETTI, R. et al. Epigenetic-based therapy: From single- to multi-target approaches. International Journal of Biochemistry and Cell Biology, v. 69, p. 121-131, 2015.

BHELLA, D. et al. Significant differences in nucleocapsid morphology within the Paramyxoviridae. The Journal of general virology, v. 83, p. 1831-1839, 2002.

BIGGAR, K. K.; LI, S. S.-C. Non-histone protein methylation as a regulator of cellular signalling and function. Nature reviews. Molecular cell biology, v. 16, p. 5-17, 2014.

BLEE, T. K. P.; GRAY, N. K.; BROOK, M. Modulation of the cytoplasmic functions of mammalian post-transcriptional regulatory proteins by methylation and acetylation: a key layer of regulation waiting to be uncovered? Biochemical Society transactions, v. 43, p. 1285-1295, 2015.

BOHMWALD, K. et al. Human Respiratory Syncytial Virus: Infection and Pathology. Seminars in Respiratory and Critical Care Medicine, v. 37, p. 522-537, 2016.

BÖTTGER, A. et al. The oxygenase Jmjd6--a case study in conflicting assignments. The Biochemical journal, v. 468, p. 191-202, 2015.

BOULANGER, M.-C. et al. Methylation of Tat by PRMT6 Regulates Human Immunodeficiency Virus Type 1 Gene Expression. Journal of Virology, v. 79, p. 124-131, 2005.

-*De acordo com: ASSOCIAÇÃO BRASILEIRA DE NORMAS TÉCNICAS NBR 6023: informação e documentação: referências: elaboração. Rio de Janeiro. 2002. 
CARROMEU, C. et al. Intracellular localization of human respiratory syncytial virus L protein. Archives of Virology, v. 152, p. 2259-2263, 2007.

CHAN-PENEBRE, E. et al. A selective inhibitor of PRMT5 with in vivo and in vitro potency in MCL models. Nature chemical biology, v. 11, p. 432-437, 2015.

COLLINS, P. L.; MELERO, J. A. Progress in understanding and controlling respiratory syncytial virus: Still crazy after all these years. Virus Research, v. 162, p. 80-99, 2011.

COWTON, V. M.; MCGIVERN, D. R.; FEARNS, R. Unravelling the complexities of respiratory syncytial virus RNA synthesis. Journal of General Virology, v. 87, p. 1805-1821, 2016.

DE JESUS, B.L.S. Transcriptoma do vírus sincicial respiratório humano em células Hep-2. 2016. 57 f. Dissertação (Mestrado em Ciências) - Faculdade de Medicina de Ribeirão Preto, Universidade de São Paulo, Ribeirão Preto, 2016.

DHAR, S. et al. Loss of the major Type I arginine methyltransferase PRMT1 causes substrate scavenging by other PRMTs. Scientific reports, v. 3, p. 1311, 2013.

DHEEKOLLU, J. et al. HCF1 and OCT2 Cooperate with EBNA1 To Enhance OriPDependent Transcription and Episome Maintenance of Latent Epstein-Barr Virus. Journal of Virology, v. 90, p. 5353-5367, 2016.

DUNCAN, K. W. et al. Structure and Property Guided Design in the Identification of PRMT5 Tool Compound EPZ015666. ACS Medicinal Chemistry Letters, v. 7, p. 162-166, 2015.

DUONG, F.; CHRISTEN, V.; BERKE, J. E. A. Upregulation of protein phosphatase 2Ac by hepatitis C virus modulates NS3 helicase activity through inhibition of protein arginine methyltransferase 1. Journal of Virology, v. 79, p. 15342-15350, 2005.

ESSE, R; LEANDRO, P.; RIVERA, I.; ALMEIDA, I. T.; BLOM, H. J.; CASTRO, R. Deciphering Protein Arginine Methylation in Mammals. In: DRICU, A. Methylation-from DNA, RNA, and Histones to Diseases and Treatment. Rijek: InTech, 2012. Cap. 4, p 91 - 116.

FIX, J. The Insertion of Fluorescent Proteins in a Variable Region of Respiratory Syncytial Virus L Polymerase Results in Fluorescent and Functional Enzymes But with Reduced Activities. The Open Virology Journal, v. 5, p. 103-108, 2011.

GALlOUX, M. et al. Characterization of a Viral Phosphoprotein Binding Site on the Surface of the Respiratory Syncytial Nucleoprotein. Journal of Virology, v. 86, p. 8375-8387, 2012.

GREENBLATT, S. M.; LIU, F.; NIMER, S. D. Arginine methyltransferases in normal and malignant hematopoiesis. Experimental Hematology, v. 44, p. 435-441, 2016.

GU, Z. et al. Protein Arginine Methyltransferase 5 Functions in Opposite Ways in the Cytoplasm and Nucleus of Prostate Cancer Cells. PLoS ONE, v. 7, p. e44033, 2012.

HAMADA, S. et al. Design, synthesis, enzyme-inhibitory activity, and effect on human cancer cells of a novel series of jumonji domain-containing protein 2 histone demethylase inhibitors. Journal of Medicinal Chemistry, v. 53, p. 5629-5638, 2010.

HAMAMOTO, R.; SALOURA, V.; NAKAMURA, Y. Critical roles of non-histone protein lysine methylation in human tumorigenesis. Nature Publishing Group, v. 15, p. 110-124, 2015. 
HE, Y. et al. Targeting protein lysine methylation and demethylation in cancers Proteins that are Subject to Lysine Methylation Potential Biological Functions of PKMTs in Cancers. Acta biochimica et biophysica Sinica, v. 44, p. 70-79, 2012.

HO, M. C. et al. Structure of the Arginine Methyltransferase PRMT5-MEP50 Reveals a Mechanism for Substrate Specificity. PLoS ONE, v. 8, 2013.

HOGAN, A. B. et al. Exploring the dynamics of respiratory syncytial virus ( RSV ) transmission in children. Theoretical Population Biology, v. 110, p. 78-85, 2016.

HU, H. et al. Small Molecule Inhibitors of Protein Arginine Methyltransferases. Expert Opinion on Investigational Drugs, v. 25, p. 335-358, 2016.

INVERNIZZI, C. F. et al. PRMT6 diminishes HIV-1 Rev binding to and export of viral RNA. Retrovirology, v. 3, p. 93, 2006.

KALLIRI, E.; GRZYSKA, P. K.; HAUSINGER, R. P. Kinetic and spectroscopic investigation of CoII, Ni II, and N-oxalylglycine inhibition of the FeII/??- ketoglutarate dioxygenase, TauD. Biochemical and Biophysical Research Communications, v. 338, p. 191-197, 2005.

KARKHANIS, V. et al. Versatility of PRMT5-induced methylation in growth control and development. Trends in Biochemical Sciences, v. 36, p. 633-641, 2011.

KRISTIE, T. M. Chromatin Modulation of Herpesvirus Lytic Gene Expression: Managing Nucleosome Density and Heterochromatic Histone. American Society for Microbiology, v. 7, p. 1-3, 2016.

KWAK, Y. T. et al. Methylation of SPT5 regulates its interaction with RNA polymerase II and transcriptional elongation properties. Molecular Cell, v. 11, p. 1055-1066, 2003.

LANOUETTE, S. et al. The functional diversity of protein lysine methylation. Molecular Systems Biology, v. 10, p. 1-26, 2014.

LAWRENCE, P.; CONDERINO, J. S.; RIEDER, E. Redistribution of demethylated RNA helicase A during foot-and-mouth disease virus infection: Role of jumonji c-domain containing protein 6 in RHA demethylation. Virology, v. 452-453, p. 1-11, 2014.

LEE, Y.-H.; STALLCUP, M. R. Minireview: protein arginine methylation of nonhistone proteins in transcriptional regulation. Molecular endocrinology, v. 23, p. 425-433, 2009.

LIU, W. et al. Brd4 and JMJD6-associated anti-pause enhancers in regulation of transcriptional pause release. Cell, v. 155, p. 1581-1595, 2013.

LOZANO, R. et al. Global and regional mortality from 235 causes of death for 20 age groups in 1990 and 2010: A systematic analysis for the Global Burden of Disease Study 2010. The Lancet, v. 380, p. 2095-2128, 2012.

MITRA, R. et al. The Human Respiratory Syncytial Virus Matrix Protein Is Required for Maturation of Viral Filaments. Journal of Virology, v. 86, p. 4432-4443, 2012.

MORALES, Y. et al. Biochemistry and regulation of the protein arginine methyltransferases (PRMTs). Archives of Biochemistry and Biophysics, v. 590, p. 138-152, 2016.

MOREIRA, F. B. Infecções por Vírus Sincicial Respiratório (VSR) no período de dois anos: Epidemiologia molecular e impacto clínico. 2015. Dissertação (Mestre em microbiologia, parasitologia e patologia) - Setor de Ciências Biológicas, Universidade Federal do Paraná, Curitiba, 2015. 
MURPHY, L. B. et al. Investigations into the amino-terminal domain of the respiratory syncytial virus nucleocapsid protein reveal elements important for nucleocapsid formation and interaction with the phosphoprotein. Virology, v. 307, p. 143-153, 2003.

NAIR, H. et al. Global burden of acute lower respiratory infections due to respiratory syncytial virus in young children: a systematic review and meta-analysis. The Lancet, v. 375, p. 1545-1555, 2010.

NICHOLAS, C. et al. PRMT5 Is Upregulated in Malignant and Metastatic Melanoma and Regulates Expression of MITF and p27Kip1. PLoS ONE, v. 8, p. 1-9, 2013.

OLIVEIRA, A. P. Caracterização da nucleoproteína e fosfoproteína do Vírus Respiratório Sincicial Humano quanto suas propriedades imunogênicas e de interação com proteínas celulares. 2013. 161p. Tese (Doutorado em Ciência) - Instituto de Ciências Biomédicas, Universidade de São Paulo, São Paulo, 2013.

OLIVEIRA, A. P. et al. Human respiratory syncytial virus N, P and M protein interactions in HEK-293T cells. Virus Research, v. 177, p. 108-112, 2013.

PAHLICH, S.; ZAKARYAN, R. P.; GEHRING, H. Protein arginine methylation: Cellular functions and methods of analysis. Biochimica et biophysica acta, v. 1764, p. 1890-1903, 2006.

PANFIL, A. R. et al. PRMT5 Is Upregulated in HTLV-1-Mediated T-Cell Transformation and Selective Inhibition Alters Viral Gene Expression and Infected Cell Survival. Viruses, v. 8, p. 1-20, 2016.

PRETEL, E.; CAMPOREALE, G.; DE PRAT-GAY, G. The Non-Structural NS1 Protein Unique to Respiratory Syncytial Virus: A Two-State Folding Monomer in Quasi-Equilibrium with a Stable Spherical Oligomer. PLoS ONE, v. 8, p. 1-9, 2013.

RAMEIX-WELTI, M.-A. et al. Visualizing the replication of respiratory syncytial virus in cells and in living mice. Nature Communications, v. 5, p. 5104, 2014.

RIOUX, N. et al. Species differences in metabolism of EPZ015666, an oxetane-containing protein arginine methyltransferase-5 (PRMT5) inhibitor. Xenobiotica, v. 46, p. 1-10, 2015.

RODRÍGUEZ, L. et al. Human respiratory syncytial virus matrix protein is an RNA-binding protein: Binding properties, location and identity of the RNA contact residues. Journal of General Virology, v. 85, p. 709-719, 2004.

SIMABUCO F.M. Expressão das proteínas $\mathbf{N}$ e $\mathbf{P}$ do Vírus Respiratório Sincicial Humano: estudos funcionais e de imunização. 2009. Tese (Doutorado em Ciências) Instituto de Ciências Biomédicas, Universidade de São Paulo, São Paulo, 2009.

SIMABUCO, F.M. et al. Gene optimization leads to robust expression of human respiratory syncytial virus nucleoprotein and phosphoprotein in human cells and induction of humoral immunity in mice. Journal of Virology, v. 158, p. 93-99, 2009.

SAKANE, N. et al. Activation of HIV Transcription by the Viral Tat Protein Requires a Demethylation Step Mediated by Lysine-. PLoS Pathogens, v. 7, p. e1002184, 2011.

SINGHROY, D. N. et al. Automethylation of protein arginine methyltransferase 6 (PRMT6) regulates its stability and its anti-HIV-1 activity. Retrovirology, v. 10, p. 73, 2013.

SMIL, D. et al. Discovery of a dual PRMT5-PRMT7 inhibitor. ACS Medicinal Chemistry Letters, v. 6, p. 408-412, 2015. 
SPANNHOFF, A. et al. A novel arginine methyltransferase inhibitor with cellular activity. Bioorganic and Medicinal Chemistry Letters, v. 17, p. 4150-4153, 2007.

TAMURA, R. E. Estudo dos domínios Funcionais da proteína de matriz do Vírus Respiratório Sincicial Humano. 2009. Tese (Doutorado em Ciências) - Instituto de Ciências Biomédicas, Universidade de São Paulo, São Paulo, 2009.

TAWAR, R. G. et al. Crystal structure of a nucleocapsid-like nucleoprotein-RNA complex of respiratory syncytial virus. Science, v. 326, p. 1279-1283, 2009.

TRAN, T. L. et al. The nine C-terminal amino acids of the respiratory syncytial virus protein $\mathrm{P}$ are necessary and sufficient for binding to ribonucleoprotein complexes in which six ribonucleotides are contacted per N protein promoter. Journal of General Virology, v. 88, p. 196-206, 2007.

XIE, B. et al. Arginine methylation of the human immunodeficiency virus type 1 Tat protein by PRMT6 negatively affects Tat Interactions with both cyclin T1 and the Tat transactivation region. Journal of virology, v. 81, p. 4226-34, 2007.

YANG, F. et al. Proliferative role of TRAF4 in breast cancer by upregulating PRMT5 nuclear expression. Tumor Biology, v. 36, p. 5901-5911, 2015.

YOSHIMATSU, M. et al. Dysregulation of PRMT1 and PRMT6, Type I arginine methyltransferases, is involved in various types of human cancers. International Journal of Cancer, v. 128, p. 562-573, 2011.

YUI, I. et al. Novel Clinical FEatures of Recurrent Human Respiratory Syncitial Virus Infections. Anticancer Research, v. 86, p. 1629-1638, 2014.

ZHANG, G.; HUSSAIN, M.; ASGARI, S. Regulation of arginine methyltransferase 3 by a Wolbachia-induced microRNA in Aedes aegypti and its effect on Wolbachia and dengue virus replication. Insect biochemistry and molecular biology, v. 53, p. 81-8, 2014.

ZHANG, X.; HUANG, Y.; SHI, X. Emerging roles of lysine methylation on non-histone proteins. Cellular and Molecular Life Sciences, v. 72, p. 4257-4272, 2015.

ZHANG, X.; WEN, H.; SHI, X. Lysine methylation : beyond histones Modifying Enzymes for Lysine Methylation. Acta biochimica et biophysica Sinica, v. 44, p. 14-27, 2012. 